\title{
labanater

\section{Directing Drugs to Bugs: Antibiotic-Carbohydrate Conjugates Targeting Biofilm-Associated Lectins of Pseudomonas aeruginosa}

\author{
Joscha Meiers, Eva Zahorska, Teresa Röhrig, Dirk Hauck, Stefanie Wagner, and Alexander Titz*
}

Cite This: J. Med. Chem. 2020, 63, 11707-11724

Read Online
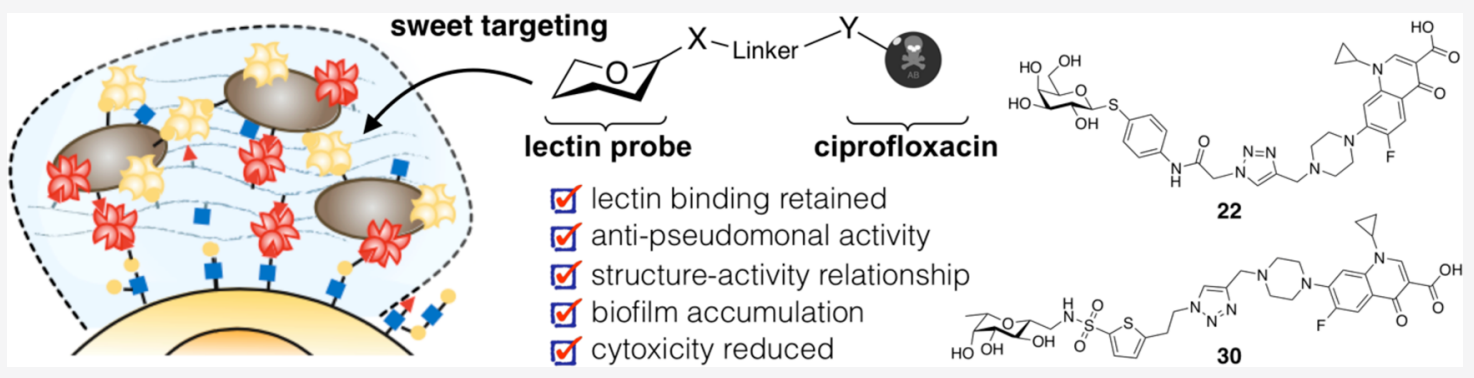

ABSTRACT: Chronic infections by Pseudomonas aeruginosa are characterized by biofilm formation, which effectively enhances resistance toward antibiotics. Biofilm-specific antibiotic delivery could locally increase drug concentration to break antimicrobial resistance and reduce the drug's peripheral side effects. Two extracellular P. aeruginosa lectins, LecA and LecB, are essential structural components for biofilm formation and thus render a possible anchor for biofilm-targeted drug delivery. The standard-of-care drug ciprofloxacin suffers from severe systemic side effects and was therefore chosen for this approach. We synthesized several ciprofloxacin-carbohydrate conjugates and established a structure-activity relationship. Conjugation of ciprofloxacin to lectin probes enabled biofilm accumulation in vitro, reduced the antibiotic's cytotoxicity, but also reduced its antibiotic activity against planktonic cells due to a reduced cell permeability and on target activity. This work defines the starting point for new biofilm/lectin-targeted drugs to modulate antibiotic properties and ultimately break antimicrobial resistance.

\section{INTRODUCTION}

The Gram-negative, opportunistic pathogen Pseudomonas aeruginosa has become a serious threat ${ }^{1-3}$ for immunocompromised patients (e.g., geriatrics, untreated HIV patients, ${ }^{4,5}$ and cancer patients ${ }^{6}$ ) and people suffering from cystic fibrosis (CF). Severe infections with $P$. aeruginosa can lead to recurrent pneumonia, lung damage, and sepsis. ${ }^{7}$ Its intrinsic antimicrobial resistance and its ability to acquire further resistances, which often lead to multidrug-/extensively drug-resistant (MDR/XDR) strains, are major obstacles for therapeutic treatment. ${ }^{8}$ As a consequence, the WHO stated $P$. aeruginosa in 2017 to be a critical priority 1 pathogen, which increases research and therapeutic focus on this particular Gramnegative pathogen. ${ }^{9}$ The ability to colonize almost any part of the human body can lead to various infected tissues, e.g., chronic wound infections, catheter-associated urinary tract infections or pneumonia, and further challenges clinicians to find an appropriate antibiotic therapy. Additionally, pharmacokinetic properties such as tissue distribution, oral bioavailability, and others vary from antibiotic to antibiotic. Thus, not every drug can reach the specific site of infection. Further, high drug levels at sensitive tissues can lead to hazardous side effects, e.g., ototoxicity of many aminoglycosides or tendon rupture and neuropathy after extensive use of fluoroquinolones.
The ability to form biofilms is a hallmark of chronic $P$. aeruginosa infections. During this stage of living, the cells cluster together in a biofilm matrix and produce a highly impenetrable barrier against host immune defense or antibiotics. $^{10,11}$ These biofilm cells can show an up to 1000 -fold increase in resistance against antibiotic drugs. ${ }^{12}$ Despite the highly complex composition of the $P$. aeruginosa biofilm, the two quorum-sensing ${ }^{13}$ regulated extracellular virulence factors LecA $^{14}$ and LecB ${ }^{15}$ (formerly called PA-IL and PA-IIL ${ }^{16-18}$ ) stand out. It is assumed that these $\mathrm{Ca}^{2+}$-dependent tetravalent proteins crosslink bacteria with the biofilm matrix as well as host tissue via glycan binding (Figure 1). It was shown that these carbohydrate-binding proteins (i.e., lectins), amongst other biological roles, are crucial for biofilm formation and its structural integrity by $P$. aeruginosa. ${ }^{14,15}$ In the case of the Dmannose(D-Man)- and L-fucose(L-Fuc)-binding LecB, da Silva et al. recently showed that it organizes the localization of the

Received: May 20, 2020

Published: September 14, 2020 


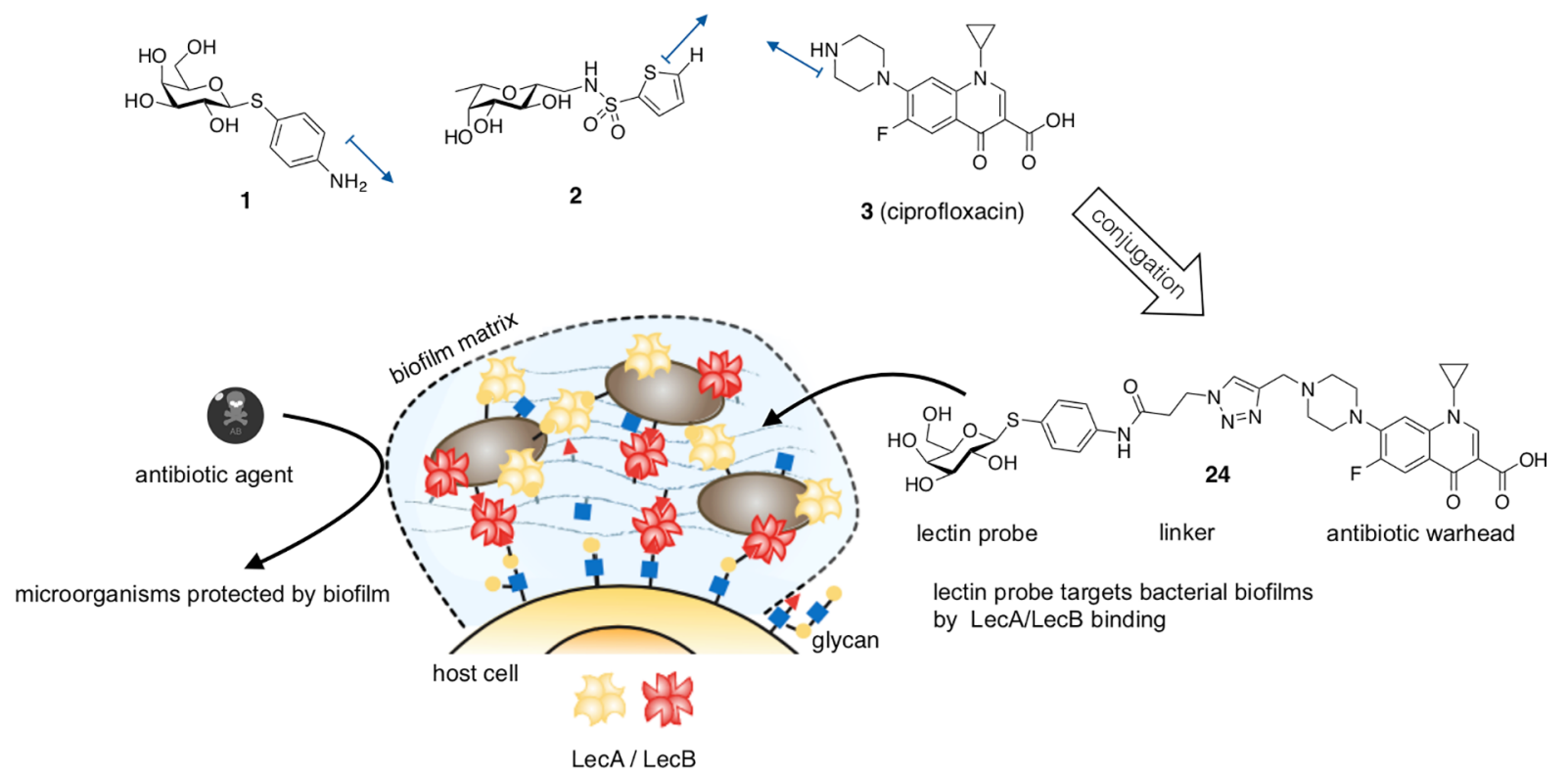

Figure 1. The lectin inhibitors 1 and 2 are conjugated to the antibiotic ciprofloxacin (3) resulting in pathogen-specific, lectin-targeted antibiotics. These compounds target the biofilm-associated lectins LecA and LecB and therefore increase local antibiotic concentration at the site of infection, resulting in fewer side effects caused by unspecific distribution and tissue accumulation. Blue arrows display growth vectors used in this work.

exopolysaccharide Psl in the biofilm matrix. ${ }^{19}$ Further, both lectins also play roles in the direct infection process: LecB conveys virulence through carbohydrate-dependent inhibition of human ciliary beating, ${ }^{20}$ interference with repair of wounded tissues, ${ }^{21,22}$ and activation of B-cells. ${ }^{23}$ Next to its biofilmrelated roles, it was shown that the D-galactose-binding LecA triggers host cell signaling pathways ${ }^{24}$ and mediates membrane invaginations after binding to its cellular receptor, the glycosphingolipid Gb3. ${ }^{25}$ In vivo, both proteins are involved in the $P$. aeruginosa infection process and host colonization in a murine infection model. ${ }^{26,27}$ Interestingly, a study of $P$. aeruginosa infected CF patients and a case report on a pulmonary infected infant reported that the bacterial load in infected airways can be reduced by intrapulmonary application of fucose and galactose. ${ }^{28-30}$ Although $P$. aeruginosa is genetically highly diverse and adaptable, ${ }^{31,32}$ the protein sequence of LecA is highly conserved amongst clinical isolates. On the other hand, LecB does vary and can be clustered in either PAO1-like or PA14-like structures. ${ }^{33}$ However, both LecB variants bind to same glycosides, making the design of LecB-inhibitors against a wide range of clinical $P$. aeruginosa strain isolates possible. ${ }^{33,34}$

Lectin-carbohydrate interactions are usually characterized by weak binding affinity, which Nature circumvents by multivalent presentation of ligand or receptor. ${ }^{35}$ Due to the high therapeutic interest, many compounds have been designed to inhibit LecA or LecB, ${ }^{36-38}$ most of them showing high affinity on the target in a multivalent fashion. ${ }^{39,40}$ Interestingly, LecBdirected multivalent molecules with nanomolar on-target activity required millimolar concentrations to inhibit biofilm formation of $P$. aeruginosa. ${ }^{26}$ One possible explanation is the creation of additional crosslinks due to the protein's and ligand's multivalent structure, resulting in an undesired stabilization of the biofilm at therapeutic concentrations of the multivalent ligand.

We have previously identified monovalent LecB inhibitors, sulfonamide-capped mannosides, and $C$-glycosides combining pharmacophores of its natural ligands, fucose and man- nose. $^{41-43}$ Recently, we reported the first drug-like, oral bioavailable LecB inhibitor 1 and established its SAR. ${ }^{44,45}$ Glycomimetic 1 showed excellent binding affinity against LecB and inhibited biofilm formation in vitro at micromolar concentrations. In mice, high plasma and urine concentrations were obtained after oral application.

Whilst LecB can be inhibited with high affinity ligands, LecA only shows moderate binding affinity against monovalent galactose-based compounds. ${ }^{36-38,46}$ Instead of a multivalent ligand presentation, we circumvented the rapid dissociation of the ligand-receptor complex by introduction of a electrophilic warhead in the first covalent lectin inhibitor. After conjugation of this galactose-based epoxide to a fluorescent dye, we used the resulting LecA-targeted dye to stain $P$. aeruginosa biofilms in vitro, proposing its potential use as biofilm-recognizing diagnostic tools. ${ }^{47}$

Fluoroquinolone antibiotics are frequently used to treat a plethora of bacterial infections. The most common representative of this class is the drug ciprofloxacin, which is amongst other indications being used in cystic fibrosis-associated bronchopulmonary $P$. aeruginosa infections. Although fluoroquinolones were originally described to be pharmacologically safe, clinical phase IV studies revealed partially irreversible side effects like tendon ruptures or neuropathy, resulting from high tissue penetration and off-target effects. As a consequence, the fluoroquinolones have been categorized by drug agencies as high risk drugs and the U.S. Food and Drug Administration (FDA) issued a "black box" warning label, ${ }^{48}$ and the German Federal Institute for Drugs and Medical devices (BfArM) informed medical professionals about prescription restrictions in 2019.

Paul Ehrlich coined the concept of a "magic bullet", describing molecules that would specifically target only pathogenic bacteria or tumor cells. ${ }^{49}$ One hundred fifty years later, this approach is on the way to become common therapeutic practice: Antibody-drug conjugates like trastuzumab-emtansine ${ }^{50}$ led to a great success in cancer therapy and are also being studied in antimicrobial research. ${ }^{51}$ Further, 
Scheme 1. Chemical Synthesis of the (A) LecA-Targeting (11-14) and (B) LecB-Targeting (19) Probes and (C) Alkyne Ciprofloxacin Derivatives 20 and $21^{a}$

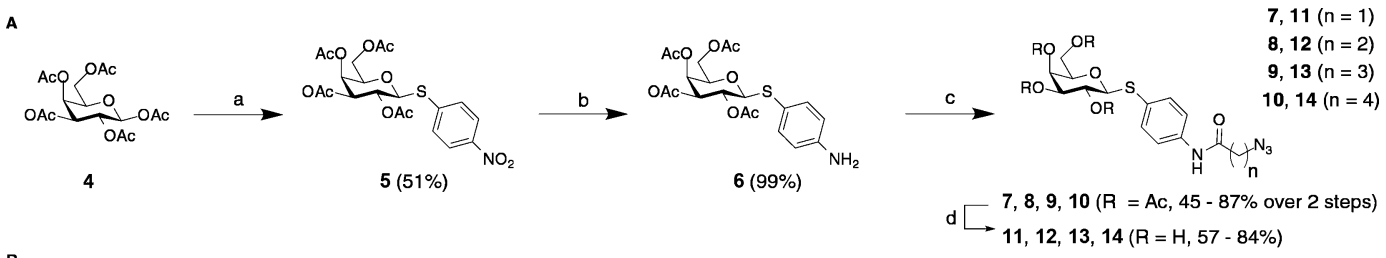

B

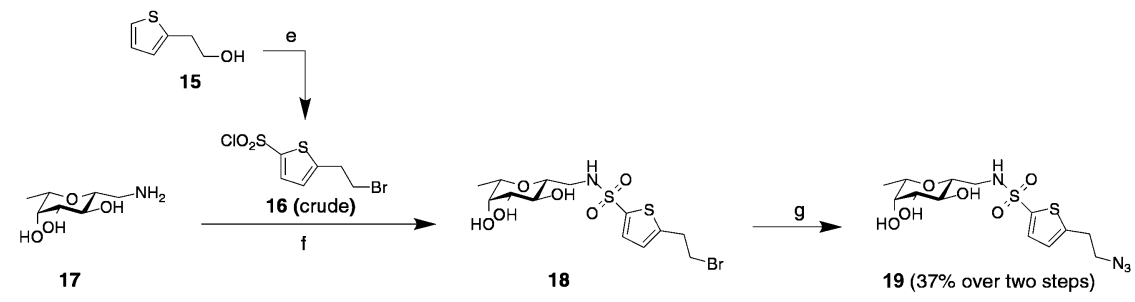

c

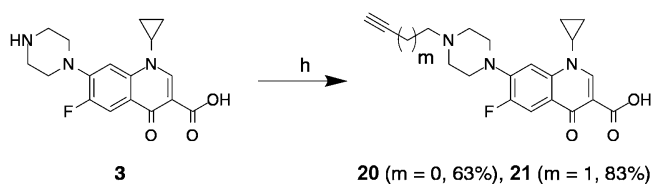

${ }^{a}$ Reagents and conditions: (a) p-nitrothiophenol, $\mathrm{BF}_{3} \cdot \mathrm{Et}_{2} \mathrm{O}, \mathrm{CH}_{2} \mathrm{Cl}_{2}, 0{ }^{\circ} \mathrm{C}$ to r.t., 16 h; $(\mathrm{b}) \mathrm{H}_{2}, \mathrm{Pd} / \mathrm{C}, \mathrm{CH}_{2} \mathrm{Cl}_{2}$, r.t., 24 h; $\left(\right.$ c) $(\mathrm{i}) \mathrm{Br}\left(\mathrm{CH}_{2}\right)_{n} \mathrm{COHal}$ $\mathrm{Et}_{3} \mathrm{~N}$, or $\mathrm{K}_{2} \mathrm{CO}_{3}$, DMF, $0{ }^{\circ} \mathrm{C}$ to r.t., $1-4$ h, (ii) $\mathrm{NaN}_{3}$, DMF, r.t., $4 \mathrm{~h}$; (d) cat. $\mathrm{NaOMe}, \mathrm{MeOH}$, r.t., 1 h; (e) (i) $\mathrm{PBr}_{3}, \mathrm{CH}_{2} \mathrm{Cl}_{2}, 0{ }^{\circ} \mathrm{C}$ to r.t., 1 h, (ii) $\mathrm{HSO}_{3} \mathrm{Cl}, \mathrm{CH}_{2} \mathrm{Cl}_{2}, 0^{\circ} \mathrm{C}$ to r.t., $3 \mathrm{~h}$; (f) crude $16, \mathrm{~K}_{2} \mathrm{CO}_{3}$, DMF, r.t., $5 \mathrm{~h}$; (g) $\mathrm{NaN}_{3}$, DMF, r.t., $5 \mathrm{~h}$; (h) propargylbromide or 4-bromo-but-1-yne, $\mathrm{Et}_{3} \mathrm{~N}, \mathrm{DMF}, 70{ }^{\circ} \mathrm{C}, 1-4 \mathrm{~d}$.

many antibiotic conjugates have been described so far, mainly targeting bacterial uptake mechanisms or non-targeted dual acting antibiotics (reviewed in refs 52, 53). Interestingly, carbohydrate conjugates of ciprofloxacin were described to increase bacterial cell uptake via sugar transporters. ${ }^{54,55}$ Inspired by the successful detection of $P$. aeruginosa biofilms with LecA-directed dyes, we aimed to conjugate glycomimetics to ciprofloxacin in order to target the extracellular $P$. aeruginosa-specific, biofilm-related virulence factors LecA and LecB. By exploiting lectin accumulation in the $P$. aeruginosa biofilm, the targeted conjugates shall deliver their antibiotic cargo specifically to the site of infection. Thus, an enhanced local drug concentration could overcome antimicrobial resistance and lower nonspecific drug distribution, potentially reducing systemic side effects (Figure 1). Here, we report the synthesis of the first lectin-targeted antibiotic conjugates and their microbiological and biochemical evaluation. We describe an antimicrobial structure-activity relationship of these lectin binding conjugates and show their biofilm accumulation in vitro.

\section{RESULTS AND DISCUSSION}

Design. The design of the lectin-targeted conjugates followed the established structure-activity relationships (SAR) of their individual components, i.e., targeting moiety and ciprofloxacin cargo.

The targeted lectins LecA and LecB both show shallow carbohydrate binding sites on their protein surfaces. As a consequence, linking a cargo to specific sites at the published probes without losing lectin inhibition activity was plausible. The SAR of D-galactose-based LecA inhibitors revealed $\beta$ linked aromatic aglycons to be vital for potent LecA inhibition. Further substitutions at the aromatic aglycon only result in minor changes in binding affinity. ${ }^{56-58}$ In the complex with LecA, the ligand's surface-exposed phenyl aglycon reveals a potential growth vector for the conjugation of cargo to the para-position. ${ }^{59}$ As this linking strategy was used to stain $P$. aeruginosa biofilms in vitro, ${ }^{47}$ we decided to similarly link an antibiotic cargo, using 1 as a LecA targeting probe. To increase the metabolic stability, the $O$-glycosidic structure was replaced with a thioglycoside. The potent LecB inhibitor 2 displays a $C$ glycosidic hybrid structure, merging target interactions of $\mathrm{D}$ mannose and L-fucose. The attachment of an aromatic sulfonamide addressed an additional subpocket on LecB. ${ }^{41-44}$ Analysis of the co-crystal structure of LecB in complex with 2 and extensive SAR studies ${ }^{45}$ revealed a potential growth vector on position 5 of the thiophene ring for subsequent conjugation to the antibiotic cargo.

Fluoroquinolones represent a highly active class of antibiotics, deriving from their predecessor nalidixic acid. The SAR of the fluoroquinolones ${ }^{60-63}$ is well described and exploited in several antimicrobial conjugates. Its main pharmacophore, 6fluoro-quinolone-3-carboxylic acid, is essential for inhibition of its intracellular target, bacterial gyrase. Substitutions at position 7 mainly modify and fine-tune pharmacokinetic properties and strain specificity. In the case of ciprofloxacin, the presence of a piperazine increases anti-pseudomodal activity. ${ }^{64}$ We chose to derivatize the synthetically accessible secondary amine of the piperazine ring to a tertiary amine as this would result only in a smaller change of its physicochemical properties that influence porin-mediated bacterial cell uptake, as compared to, e.g., amide formation. Furthermore, analysis of the co-crystal structure $^{65}$ of ciprofloxacin with the GyrA/GyrB heterodimer showed a possible growth vector at this position (Figure 1).

Copper-catalyzed Huisgen-type [3+2] cycloaddition of terminal alkynes and terminal azides was chosen as a 
Scheme 2. Assembly of the Lectin-Targeted Ciprofloxacin Conjugates ${ }^{a}$

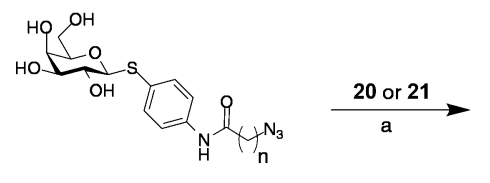

$11-14$

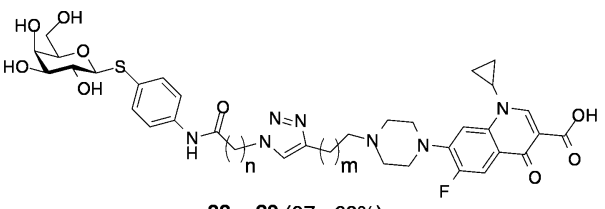

$22-29(37-68 \%)$

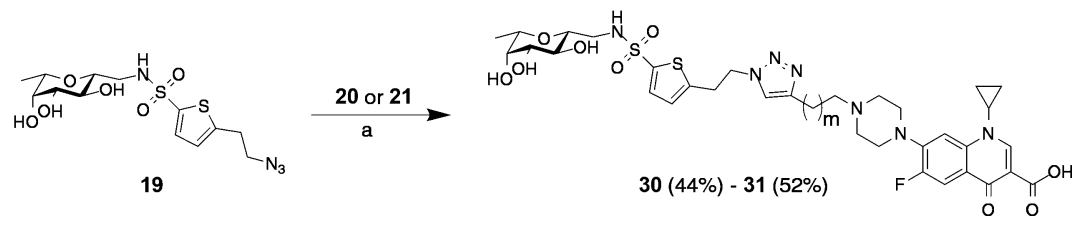

${ }^{a}$ Reagents and conditions: (a) cat. $\mathrm{CuSO}_{4}$, cat. sodium ascorbate, $\mathrm{DMF} / \mathrm{H}_{2} \mathrm{O}$, r.t. 16 h, r.t. (for 11-14) or $40{ }^{\circ} \mathrm{C}$ (for 19).
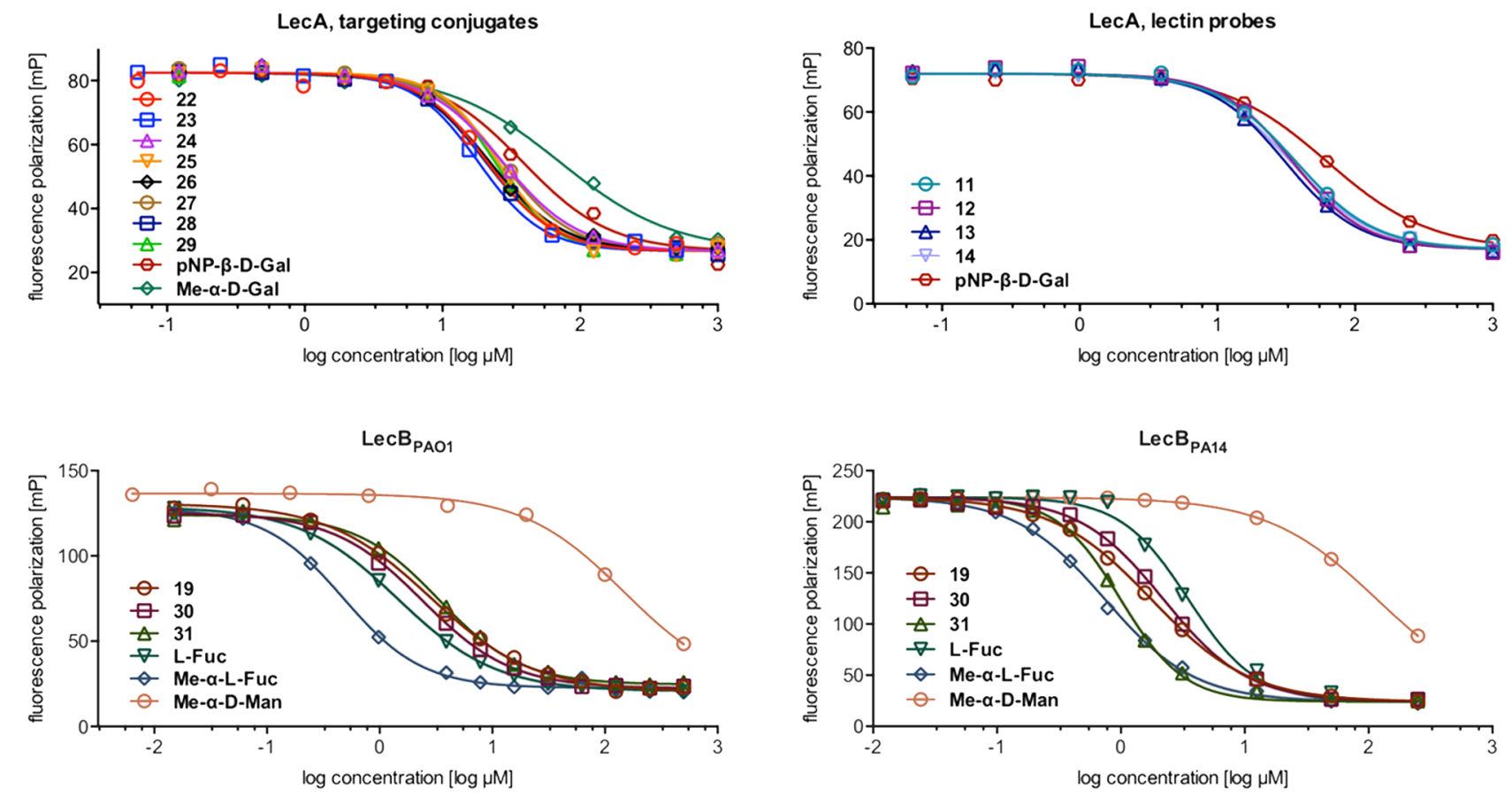

Figure 2. Competitive binding assay of lectin-targeted ciprofloxacin conjugates 22-31, lectin probes 11-14 and 19, and control compounds with $\mathrm{LecA}$, LecB $\mathrm{PAO}_{\mathrm{PA}}$, and $\mathrm{LecB}_{\mathrm{PA} 14}$. One representative titration of triplicates on one plate is shown for each compound ( $\mathrm{IC}_{50}$ in $\mathrm{Table}_{1}$ and $K_{\mathrm{i}}$ in $\mathrm{Table}$ S1).

convenient and modular way of linking both moieties. Further, we decided to analyze the impact of the linker length and flexibility on antibiotic activity by stepwise introduction of methylene spacers.

Synthesis. The LecA-targeting precursor 6 (Scheme 1) was synthesized in analogy to Casoni et al. ${ }^{66}$ Glycosylation of the acceptor para-nitrothiophenol with galactose pentaacetate (4) using $\mathrm{BF}_{3} \cdot \mathrm{Et}_{2} \mathrm{O}$ as a Lewis acid resulted in thioglycoside $\mathbf{5}$ in $51 \%$ yield. Palladium-catalyzed hydrogenation gave the corresponding aniline 6 quantitatively. Compound 6 was then treated with various $\omega$-bromo acylhalides followed by a nucleophilic substitution with sodium azide to the corresponding azides 7-10 in one pot. The usage of triethylamine during the amide coupling led to $\beta$-elimination in the case of the propionic acid derivative 7 or $\gamma$-lactam formation in the case of bromide 13, which could be circumvented by using potassium carbonate as a base. Deprotection of acetates 7-10 under Zemplén conditions resulted in the LecA-probes 11-14.
Based on the results from the antimicrobial susceptibility testing (vide infra), we synthesized only one LecB probe (Scheme 1). $\beta$-C-glycoside 17 was synthesized as reported. ${ }^{42}$ Thiophene building block 16 was synthesized from 15 in two steps: The primary alcohol $\mathbf{1 5}$ was transformed to the corresponding bromide with phosphorous tribromide followed by chlorosulfonation of the thiophene in position 5 with chlorosulfonic acid. Crude sulfonylchloride 16 was reacted with amine $\mathbf{1 7}$ to yield sulfonamide 18. This intermediate was stirred with sodium azide to give compound 19 in an overall yield of $37 \%$ over two steps based on the amine starting material 17.

Alkylation of ciprofloxacin with propargyl bromide or 4bromobut-1-yne in DMF at elevated temperatures yielded the corresponding terminal alkynes 20 and 21. Finally, coppercatalyzed 1,3-dipolar cycloaddition of alkynes 20 and 21 with azides 11-14 and 19 resulted in the lectin-targeted ciprofloxacin conjugates 22-31 (Scheme 2). 
Table 1. Competitive Binding Assay of Lectin-Targeted Ciprofloxacin Conjugates and Control Compounds with LecA, $\mathrm{LecB}_{\mathrm{PAO} 1}$, and $\mathrm{LecB}_{\mathrm{PA} 14}{ }^{a}$

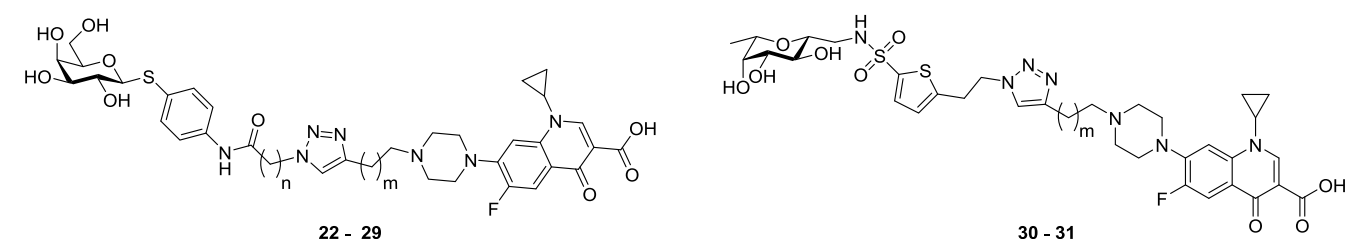

\begin{tabular}{|c|c|c|c|}
\hline \multicolumn{4}{|c|}{ LecA } \\
\hline compound & $n$ & $m$ & $\mathrm{IC}_{50} \pm$ s.d. $[\mu \mathrm{M}]$ \\
\hline 11 & 1 & \multirow{4}{*}{ LecA-probes } & $31.7 \pm 11$ \\
\hline 12 & 2 & & $30.9 \pm 8.7$ \\
\hline 13 & 3 & & $31.1 \pm 8.3$ \\
\hline 14 & 4 & & $29.9 \pm 9.5$ \\
\hline 22 & 1 & 0 & $30.4 \pm 8.0$ \\
\hline 23 & 1 & 1 & $21.6 \pm 5.5$ \\
\hline 24 & 2 & 0 & $32.2 \pm 3.3$ \\
\hline 25 & 2 & 1 & $28.0 \pm 1.8$ \\
\hline 26 & 3 & 0 & $27.3 \pm 4.0$ \\
\hline 27 & 3 & 1 & $29.3 \pm 3.7$ \\
\hline 28 & 4 & 0 & $28.3 \pm 8.1$ \\
\hline 29 & 4 & 1 & $26.2 \pm 2.4$ \\
\hline Me- $\alpha$-D-Gal & \multirow{2}{*}{\multicolumn{2}{|c|}{ controls }} & $71.7 \pm 16$ \\
\hline pNP- $\beta$-D-Gal & & & $52.7 \pm 13$ \\
\hline & & LecB $_{\mathrm{PAO} 1}$ & $\mathrm{LecB}_{\mathrm{PA} 14}$ \\
\hline compound & $m$ & $\mathrm{IC}_{50} \pm$ s.d. $[\mu \mathrm{M}]$ & $\mathrm{IC}_{50} \pm$ s.d. $[\mu \mathrm{M}]$ \\
\hline 19 & LecB-probe & $3.91 \pm 1.6$ & $1.87 \pm 0.21$ \\
\hline 30 & 0 & $2.37 \pm 1.2$ & $2.24 \pm 0.23$ \\
\hline 31 & 1 & $2.53 \pm 0.87$ & $1.00 \pm 0.06$ \\
\hline Me- $\alpha$-D-Man & & $166 \pm 22$ & $101 \pm 10$ \\
\hline L-Fuc & controls & $2.63 \pm 1.7$ & $2.46 \pm 0.33$ \\
\hline Me- $\alpha$-L-Fuc & & $0.534 \pm 0.07$ & $0.79 \pm 0.11$ \\
\hline
\end{tabular}

${ }^{a}$ Means and standard deviations were determined from a minimum of three independent experiments. $K_{\mathrm{i}}$ calculated from $\mathrm{IC}_{50}$ is shown in Table $\mathrm{S} 1$.

Biophysical and Microbiological Evaluation. Competitive Lectin Binding Assay Based on Fluorescence Polarization. To analyze lectin binding of the targeted antibiotics, we quantified their binding affinity to LecA or LecB in the previously reported competitive binding assays. ${ }^{33,41,58}$

The binding affinity of the LecA-targeting conjugates 22-29 did not significantly differ from their corresponding lectin probes 11-14 (Figure 2 and Table 1), reaching $\mathrm{IC}_{50}$ values from 26 to $30 \mu \mathrm{M}$. Thus, they show an up to 2 -fold increased inhibitory activity against LecA compared to $p$-nitrophenyl $\beta$ D-galactoside (pNP- $\beta$-D-Gal, $\left.\mathrm{IC}_{50}=52.7 \pm 13 \mu \mathrm{M}\right)$ and an up to 3 -fold increase compared to methyl $\alpha$-D-galactoside (Me- $\alpha$ D-Gal, $\left.\mathrm{IC}_{50}=71.7 \pm 16 \mu \mathrm{M}\right)$, which served as reference compounds in this study.

Competitive binding assays against $\mathrm{LecB}_{\mathrm{PAO} 1}$ (Figure 2 and Table 1) revealed $\mathrm{IC}_{50}$ values in the one digit micromolar range for LecB probe $19\left(\mathrm{IC}_{50}=3.91 \pm 1.6 \mu \mathrm{M}\right)$ and its corresponding conjugates 30 and $31\left(\mathrm{IC}_{50}=2.37 \pm 1.2\right.$ and $2.53 \pm 0.87 \mu \mathrm{M}$, respectively), which is in the range of $\mathrm{L}$-fucose $\left(\mathrm{IC}_{50}=2.63 \pm 1.7 \mu \mathrm{M}\right)$. The two glycosides, methyl $\alpha$-Dmannoside (Me- $\alpha$-D-Man) and methyl $\alpha$-L-fucoside (Me- $\alpha$-LFuc), which resemble terminal glycan structures recognized by LecB showed $\mathrm{IC}_{50}$ values of $166 \pm 22$ and $0.534 \pm 0.07 \mu \mathrm{M}$, respectively. The inhibition assay on $\mathrm{LecB}_{\mathrm{PA} 14}$ showed similar trends (Table 1). As observed previously, ${ }^{33}$ LecB $_{\text {PA14 }}$ binds its ligands with higher affinity (e.g., $\mathrm{IC}_{50}$ of $1.00 \mu \mathrm{M}$ vs $2.53 \mu \mathrm{M}$ for compound 31). Since P. aeruginosa PA14 and PAO1 are representative for many clinical isolates, a broad range of $P$. aeruginosa strains can be targeted by these conjugates.

Comparing the conjugates with the unlinked lectin probes showed in all cases a comparable binding affinity. Further, all compounds showed better binding than Me- $\alpha$-D-Gal (LecA) or Me- $\alpha$-D-Man (LecB). Due to the highly optimized structure of the fucose-mannose pharmacophore, the LecB targeting compounds were comparably active on LecB as L-fucose. In conclusion, the topology of the carbohydrate binding sites in both proteins allowed the conjugation with an antibiotic cargo without influencing lectin binding.

Antibiotic Susceptibility Assay. The antibiotic activity of lectin-targeted ciprofloxacin conjugates 22-31 was tested against a panel of Gram-positive and Gram-negative bacteria (Table 2). The model organisms E. coli MG1655 (a common lab strain), E. coli DSM 1116 (an antibiotic susceptibility reference strain recommended by the DSMZ), and the Grampositive Staphylococcus carnosus DSM 20501 were tested first to assess Gram-negative specific antibiotic activity and strain specificity. Afterward, the antibiotic activity against the two $P$. aeruginosa strains PA14 and PAO1 was studied. These two important reference strains represent a broad range of clinical isolates and are well studied in the literature. ${ }^{33}$ To determine the effect of the lectins' presence on antibiotic activity, we used the lectin-deficient knockout mutants of P. aeruginosa PA14, i.e., PA14 $\Delta l e c A$ and PA14 $\Delta l e c B$. Ciprofloxacin (3) and the synthetic intermediate $\mathbf{2 0}$ were used as reference compounds 
Table 2. Antibacterial Activity of Lectin Targeted Conjugates 22-31, 20, and Ciprofloxacin (3) against a Panel of Bacterial Organisms. LecA-targeting galactosides were generally more active than the LecB-targeting conjugates. A shorter linker length on the side of the antibiotic led to increased antimicrobial activity ${ }^{a}$

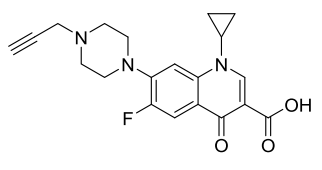

20

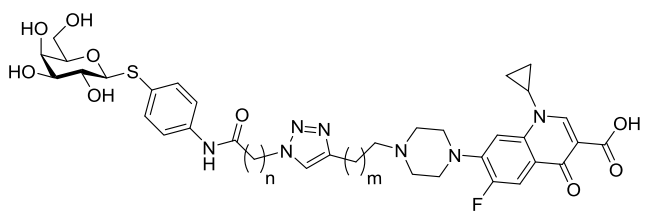

$22-29$

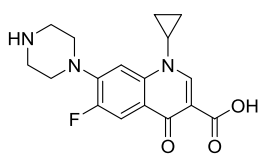

3

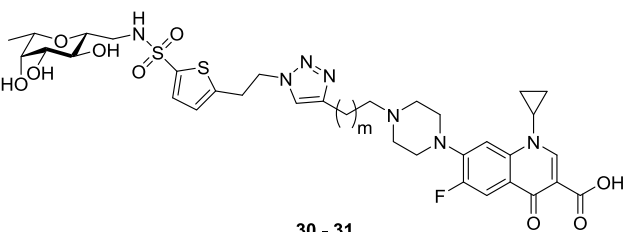

$30-31$

\begin{tabular}{ccccc}
\multicolumn{2}{c}{ target: } & LecB & & \multicolumn{2}{c}{ references } \\
\cline { 1 - 2 } \cline { 5 - 5 } \cline { 5 - 5 } $\mathbf{3 0}$ & $\mathbf{3 1}$ & & $\mathbf{2 0}$ & $\mathbf{3}$ \\
761.8 & 775.9 & & 369.4 & 331.3
\end{tabular}

\begin{tabular}{ccccr} 
& & & \multicolumn{2}{c}{ target: LecA } \\
\hline $\mathbf{2 2}$ & $\mathbf{2 3}$ & $\mathbf{2 4}$ & $\mathbf{2 5}$ & $\mathbf{2 6}$ \\
739.8 & 753.8 & 753.8 & 767.8 & 767.8
\end{tabular}

$1 / 0 \quad 1 / 1$

$2 / 0$

$2 / 1$

$3 / 0$

$3 / 1$

$\begin{array}{cc}28 & 29 \\ 781.9 & 795.9 \\ 4 / 0 & 4 / 1\end{array}$

$-/ 0$

0

\begin{tabular}{|c|c|c|c|c|c|c|c|c|c|c|c|c|}
\hline \multirow{2}{*}{$\begin{array}{l}\text { test organism } \\
\text { E. coli K12 MG1655 }\end{array}$} & \multicolumn{12}{|c|}{$\operatorname{MIC}[\mu \mathrm{g} / \mathrm{mL}]$} \\
\hline & 2 & $8-16$ & 2 & 16 & $1-2$ & 16 & $2-4$ & 16 & $8-16$ & 16 & n.d. & $<0.125$ \\
\hline E. coli DSM 1116 & $2-4$ & 16 & $2-4$ & 32 & $2-32$ & $4-32$ & $4-32$ & $4-32$ & $16-32$ & 32 & n.d. & $<0.125$ \\
\hline S. carnosus DSM 20501 & 32 & 64 & 32 & $>64$ & 16 & 64 & 8 & $\geq 64$ & $>64$ & $>64$ & n.d. & $<0.125$ \\
\hline P. aeruginosa PA14 wt & 16 & $\geq 64$ & $8-16$ & $>64$ & $8-16$ & $>64$ & 32 & $>64$ & 64 & $>64$ & $2-4$ & $0.025-0.1$ \\
\hline $\begin{array}{l}\text { P. aeruginosa PA14 wt } \\
+1 \mu \mathrm{g} / \mathrm{mL} \text { PMBN }\end{array}$ & $4-16$ & $16-64$ & $8-16$ & $32-64$ & 4 & $32-64$ & $2-8$ & $32-64$ & 64 & 64 & $0.025-0.5$ & 0.025 \\
\hline P. aeruginosa PA14 $\Delta l e c A$ & $16-32$ & $\geq 64$ & $8-16$ & $>64$ & $8-16$ & $>64$ & 32 & $>64$ & $\geq 64$ & $>64$ & $4-8$ & $0.05-0.08$ \\
\hline P. aeruginosa PA14 $\Delta l e c B$ & $16-32$ & $\geq 64$ & $8-32$ & $>64$ & $8-16$ & $>64$ & $32-64$ & $>64$ & 64 & $>64$ & 4 & $0.05-0.08$ \\
\hline P. aeruginosa $\mathrm{PAO} 1 \mathrm{wt}$ & $16-32$ & $>64$ & 16 & $>64$ & $16-32$ & $>64$ & $32-64$ & $>64$ & $\geq 64$ & $>64$ & $4-8$ & $0.025-0.08$ \\
\hline P. aeruginosa PAO1 wt & $4-8$ & $32-64$ & $4-8$ & $32-64$ & $4-8$ & $32-64$ & $8-16$ & $32-64$ & $32-64$ & $\geq 64$ & $1-2$ & $0.025-0.05$ \\
\hline
\end{tabular}
$+1 \mu \mathrm{g} / \mathrm{mL}$ PMBN

${ }^{a}$ Data is presented as minimal inhibitory concentration (MIC) range from at least three independent experiments. Molar MIC is given in Table S2. n.d. = not determined.

to study the effect of piperazine $N$-alkylation on antibiotic activity.

Ciprofloxacin is known to be particularly active against Gram-negative compared to Gram-positive organisms. Both E. coli strains showed higher susceptibility against the ciprofloxacin conjugates than the Gram-positive organism $S$. carnosus. Comparing both E. coli strains, the antibiotic susceptibility reference strain (DSM 1116) showed similar or slightly higher MIC values (Table 2).

Compared to E. coli, P. aeruginosa PA14 and PAO1 both showed lower susceptibility against all compounds tested, which was expected due to the well-known increased intrinsic antimicrobial resistance of $P$. aeruginosa. It was also observed that the clinical isolate PAO1 was similarly or slightly less susceptible than the clinical isolate PA14. Importantly, some of the lectin-targeted conjugates reached antibiotic activity down to $8 \mu \mathrm{g} / \mathrm{mL}$ against planktonic $P$. aeruginosa (Table 2).

Comparing the MIC values amongst the different conjugates and the reference compounds 20 and ciprofloxacin (3), we observed a structure-activity relationship: Conjugates containing galactosides as lectin-targeting probes showed higher antimicrobial activity than LecB-targeting compounds, which are based on a $\mathrm{C}$-glycosidic hybrid structure. It has been previously postulated that galactosides are recognized by the bacterial sugar uptake machinery, ${ }^{54,55}$ which would result in an active transportation over the Gram-negative cell wall. A comparative study by O'Shea and Moser ${ }^{68}$ on commonly used antibiotics showed that especially $P$. aeruginosa active compounds have $\operatorname{cog} \mathrm{D}$ values of $<0 . \log \mathrm{D}$ calculation (data not shown) of all conjugates $\mathbf{2 2 - 3 1}$ and $\mathbf{2 0}$ revealed positive values, which could explain the reduction in antimicrobial activity with respect to ciprofloxacin (3) showing a $\operatorname{clog} \mathrm{D}$ of $<0$.

Further, a decreased linker length between triazole and ciprofloxacin (entitled $\mathrm{m}$ in the structure drawings) amplified the antibiotic activity in all cases, independent of the carbohydrate probe or microorganism tested. This effect becomes most evident in case of E. coli K12 MG1655, where an up to 8-fold increase in MIC could be observed (e.g., 24 vs 25, Table 2). We assume that changing the distance between the tertiary amine and the electron-withdrawing triazole affects the amine's basicity, which is believed to play a role in porin diffusion. ${ }^{67}$ The parent drug ciprofloxacin reached MIC values of $0.025-0.1 \mu \mathrm{g} / \mathrm{mL}$ against $P$. aeruginosa, while the propargylated derivative 20 showed MIC values of $2-4 \mu \mathrm{g} /$ $\mathrm{mL}$ against $P$. aeruginosa PA14 and $4-8 \mu \mathrm{g} / \mathrm{mL}$ against $P$. aeruginosa $\mathrm{PAO} 1$, thereby reaching the concentration range of the most potent conjugates. As alkylation of ciprofloxacin alone already led to a significant decrease in activity, conjugation at the secondary amine in the piperazine ring is most likely responsible for the decreased antibiotic activity. ${ }^{60-62}$

Regarding total linker size, increasing length resulted in higher MIC values (e.g., 22 vs 29), which can be explained by a size exclusion effect of outer membrane porins. It is believed 
that these barrel-formed, hydrophilic channels play crucial roles for membrane permeation of hydrophilic compounds and are limited to a certain molecular weight or three-dimensional molecular structure ${ }^{67,68}$ Further, the introduction of additional methylene groups results in an increased number of rotatable bonds and increased lipophilicity, which is also described to reduce bacterial cell uptake. ${ }^{67,68}$ We compared retention times from reversed-phase HPLC analyses as a surrogate parameter for lipophilicity (Table S4 and Figure S4). Two trends were observed that correlated with the antimicrobial activity assays: (i) In general, all galactose-based conjugates showed lower retention times than the $C$-glycosides indicative for higher polarity, and (ii) the stepwise introduction of methylene groups in both linkers led to a stepwise increase in retention times indicating higher lipophilicity, which correlated with the reduced antimicrobial activity. Only the shortest galactosebased conjugates 22 and 23 ( $n=1, m=0$ or 1 , respectively) showed retention times slightly higher than expected in their series, which may be a result of an intramolecular hydrogen bonding between the amide $\mathrm{NH}$ and the central nitrogen atom of the triazole for $n=1$ altering their conformation and thus their physicochemical properties. We observed that the most anti-Pseudomonas active compound $\mathbf{2 4}$ showed the lowest retention time amongst the conjugates. Thus, we conclude that the conjugates' lipophilicity is an important parameter for antimicrobial activity. Ciprofloxacin (3) was eluted much earlier than all conjugates, reflecting its higher hydrophilicity.

Polymyxin B nonapeptide (PMBN) is a membrane-active antimicrobial compound that is used at sub-MIC concentrations to increase outer membrane permeability. Without being lethal to the microbe, this can provide information on bacterial cellular uptake of antimicrobial drugs. In our studies, all conjugates, except 24 and 30, benefit from the presence of the permeabilizer at least twofold (e.g., 26, Table 2). Interestingly, the MIC of reference compound $\mathbf{2 0}$ was increased most and reached high antimicrobial activity approximating ciprofloxacin. Thus, the drop in antibiotic activity for the conjugates can partially be explained by decreased cell wall permeability, as a consequence of derivatization of the secondary amine. As expected, unmodified ciprofloxacin benefitted only marginally by the addition of PMBN.

Gyrase-Dependent DNA Supercoiling Inhibition Assay. The antimicrobial susceptibility assays revealed a decrease in antibiotic activity after conjugation (Table 2 ). We showed that this decrease is most likely caused by a reduced bacterial cellular uptake as shown by the co-incubation experiments with membrane permeabilizer. However, the addition of PMBN did not result in MIC values comparable to ciprofloxacin, suggesting that further features are affected by conjugation of ciprofloxacin to the lectin probes. Thus, we investigated the compounds' ability to inhibit bacterial gyrase, the target of ciprofloxacin.

We compared the gyrase inhibition activity of three conjugates (22, 23, and 30), while the propargylated ciprofloxacin derivative 20 and unmodified ciprofloxacin (3) were used as controls (Figure 3). Gyrase-inhibition leads to a reduction of supercoiled DNA, which can be visualized by gel electrophoresis. Ciprofloxacin was the most active compound, reaching full inhibition of plasmid supercoiling in the nanomolar range. Compound $20\left(\mathrm{IC}_{50}=0.7 \pm 0.1 \mu \mathrm{M}\right)$ was less active than ciprofloxacin; however, it still showed an $\mathrm{IC}_{50}$ in the nanomolar range, suggesting that modification in this

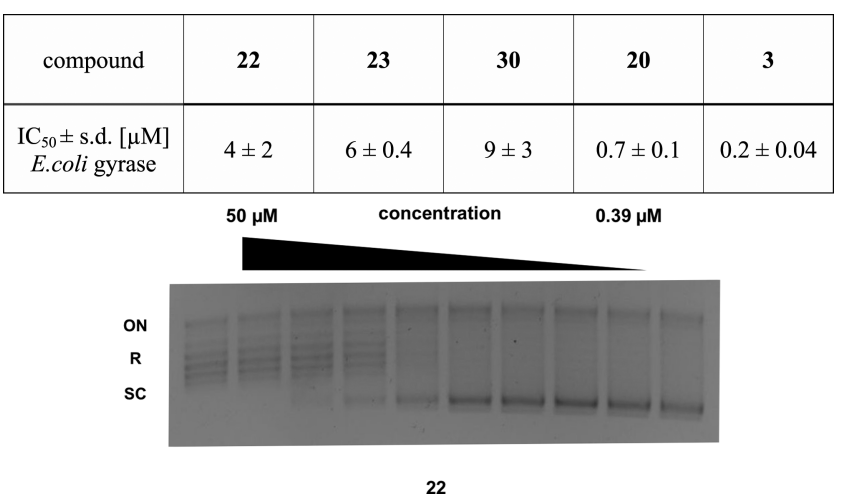

Figure 3. Effect of 20, 22, 23, 30, and ciprofloxacin (3) on gyrasecatalyzed DNA supercoiling. Propargylation (20) decreased the inhibitory concentration only by a factor of 3.5 compared to 3 . Gyrase inhibition as a putative mode of action was confirmed as all conjugates inhibit gyrase-catalyzed DNA supercoiling. Mean and standard deviations were determined from three independent experiments. A representative titration of $E$. coli gyrase with $\mathbf{2 2}$ in a supercoiling inhibition assay is shown. Controls: plasmid without gyrase and inhibitor (leftmost band) and plasmid with gyrase and without inhibitor (rightmost band). ON, open circular/nicked plasmid; R, relaxed topoisomers; SC, supercoiled topoisomers of E. coli DNA.

region of the molecule as concluded from the crystal structure analysis is indeed possible. The lectin-targeting conjugates were also potent inhibitors of gyrase supercoiling activity in the single digit micromolar range, although they were not as potent as reference compounds $\mathbf{2 0}$ and $\mathbf{3}$. This decrease in activity explains why the compounds did not reach the antibiotic activity of $N$-propargyl ciprofloxacin (20) after membrane permeabilization with PMBN.

P. aeruginosa Biofilm Accumulation Assay. Since the carbohydrate-ciprofloxacin conjugates $\mathbf{2 2 - 3 1}$ bind their respective lectins in a competitive binding assay, we investigated the ability of two representative lectin-targeting conjugates to accumulate in $P$. aeruginosa biofilms in vitro (Figure 4).

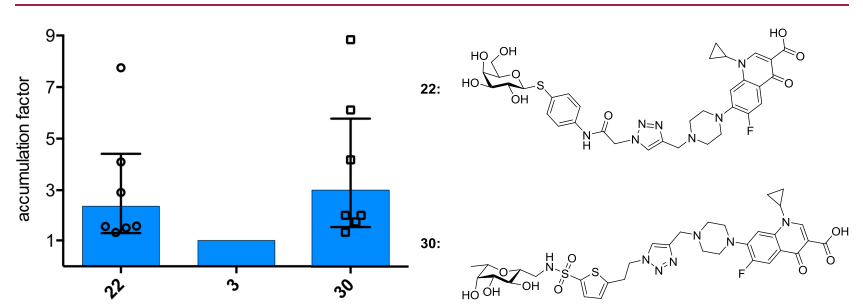

Figure 4. Accumulation of 22 (targeting LecA) and 30 (targeting $\mathrm{LecB}$ ) in $P$. aeruginosa PAO1 biofilm relative to ciprofloxacin (3). Each data point reflects the relative accumulation compared to ciprofloxacin of a single independent assay with at least three technical replicates. Bars show geometric mean and $95 \%$ confidence interval (see the Supporting Information for more detailed information, Figure S2).

For this purpose, biofilms were grown on peg lids in a 96well format that allows incubation and washing steps in a batch format. After $24 \mathrm{~h}$ of bacterial growth, P. aeruginosa PAO1 formed a visible biofilm on the pegs, which was used for compound accumulation assays. After one washing step to remove planktonic bacteria, the biofilm was immersed for 10 min into solutions containing two lectin-targeting conjugates (22 and 30) or ciprofloxacin (3) at $100 \mu \mathrm{M}$. After a 
Table 3. Early ADMET Data on Two Representative Lectin-Targeted Conjugates (22 and 30) and Ciprofloxacin (3): All Compounds Were Metabolically Stable in Human Plasma and Microsomal Fractions. Cytotoxicity was reduced compared to ciprofloxacin $^{a}$

\begin{tabular}{|c|c|c|c|c|c|c|}
\hline \multirow[b]{3}{*}{ compound } & \multicolumn{3}{|c|}{ metabolic stability } & \multirow{3}{*}{$\frac{\text { plasma protein binding }[\%]}{\text { human plasma }}$} & \multirow{2}{*}{\multicolumn{2}{|c|}{ cytotoxicity @ $100 \mu \mathrm{M}$ [\% inhibition] }} \\
\hline & \multirow{2}{*}{$\frac{t_{1 / 2}[\mathrm{~min}]}{\text { human plasma }}$} & \multicolumn{2}{|c|}{$\mathrm{CL}_{\mathrm{MIC}}[\mu \mathrm{L} / \mathrm{min} / \mathrm{mg}$ protein $]$} & & & \\
\hline & & MLM & HLM & & HEK293 & A549 \\
\hline 22 & $>150$ & 10 & 10 & $69 \pm 7$ & $8 \pm 4$ & $5 \pm 22$ \\
\hline 30 & $>150$ & 10 & 15 & $75 \pm 10$ & $11 \pm 12$ & $-9 \pm 15$ \\
\hline 3 & $>150$ & n.d. & n.d. & $33 \pm 2$ & $48 \pm 5$ & $18 \pm 11$ \\
\hline
\end{tabular}

${ }^{a}$ Data is presented as mean and standard deviation from at least two independent experiments (exception: one experiment for $\mathrm{CL}_{\mathrm{MIC}}$ data). MLM, mouse liver microsomes; HLM, human liver microsomes; n.d., not determined.

subsequent washing step to remove an unspecifically bound compound, the biofilm was disrupted and the amount of bound compound was quantified by LC-MS/MS.

Although the assay showed variation in absolute compound binding between biological replicates (Figure S2), we observed an obvious trend: the lectin targeted conjugates reached higher concentrations in the bacterial biofilm than the unmodified ciprofloxacin, independent of their lectin targeting moiety (Figure 4). These results are fundamental for the future development of further biofilm targeting antibiotic conjugates.

In Vitro Early ADMET. Metabolic stability of two representative conjugates (22 and 30) and ciprofloxacin (3) as the parent molecule was studied in vitro against human plasma, human liver microsomes, and mouse liver microsomes (Table 3). The data reveals high metabolic stability in all matrices tested: half-life in human plasma was above $150 \mathrm{~min}$ for all compounds and microsomal clearance by mouse and human liver microsomes was very low on the lectin-targeting compounds. Both conjugates showed clearance of $10 \mu \mathrm{L} / \mathrm{min} /$ mg protein by human liver microsomes, reaching the assay's lower limit. Against mouse liver microsomes, compound $\mathbf{2 2}$ also reached the assay limit of $10 \mu \mathrm{L} / \mathrm{min} / \mathrm{mg}$ protein, whereas 30 was slightly less stable $\left(\mathrm{CL}_{\mathrm{MIC}}=15 \mu \mathrm{L} / \mathrm{min} / \mathrm{mg}\right.$ protein $)$ but still classified in the most stable category of this assay $(\leq 15$ $\mu \mathrm{L} / \mathrm{min} / \mathrm{mg}$ protein). Thus, the compounds are considered metabolically stable, fitting the molecular design approach as $S$-/C-glycosides. Both conjugates showed higher plasma protein binding than ciprofloxacin $(69 \pm 7 \%$ for $22,75 \pm$ $10 \%$ for 30 vs $33 \pm 2 \%$ for 3 ).

Acute cytotoxicity was tested against a human embryonic kidney cell line (HEK 293) and adenocarcinoma human alveolar basal epithelial cells (A549). Compounds 22 and 30 showed no cytotoxicity at $100 \mu \mathrm{M}$ after $48 \mathrm{~h}$ incubation, whereas ciprofloxacin showed detectable cytotoxicity $(48 \pm 5 \%$ inhibition) against HEK 293 cells (Table 3). Furthermore, penetration over cultured human airway epithelial cells (Calu-3 HTB-55) was assessed in vitro via a Transwell system to analyze the compounds ability to permeate over mammalian cell membranes. No detectable permeation (apical to basal) was observed for compounds 22 and $\mathbf{3 0}$ after 4 h, while $10 \%$ ciprofloxacin was permeated after $4 \mathrm{~h}$ (data not shown). The low acute toxicity against human alveolar basal epithelial cells and the low lung cell permeation suggest the possibility of pulmonal application routes for patients suffering from cystic fibrosis.

\section{CONCLUSIONS AND OUTLOOK}

Biofilms present a hallmark in chronic $P$. aeruginosa infections. The ability to protect against the host immune system and antibiotic treatment renders this chemo-mechanic barrier as a strong virulence factor. Notably, it is not advisable to solely focus MIC optimization on planktonic cells during the development of new antibiotics but rather to find new therapeutic strategies. As an example, Müsken et al. showed that biofilm susceptibility of clinical $P$. aeruginosa isolates cannot be deduced from commonly studied phenotypes like MIC or minimal bactericidal concentration values. ${ }^{69}$ Delivering antibiotics specifically to the site of infection could decrease potential side effects and enhance efficacy. In this work, we developed and characterized the first $P$. aeruginosa lectintargeted antibiotic conjugates. Based on our previous work, we conjugated ciprofloxacin to LecA and LecB probes and varied the linker length.

The antibiotic conjugates showed effective lectin binding against LecA and both LecB variants from $P$. aeruginosa PAO1 and PA14, which represent a broad range of clinical isolates of $P$. aeruginosa. A structure-activity relationship regarding the antimicrobial activity of the synthesized conjugates could be established. In general, a shorter spacer between triazole and antibiotic as well as a D-galactose-based lectin probe was preferred. The observed reduction in antibiotic activity could be rationalized due to a higher molecular weight, decreasing the ability to penetrate the Gram-negative cell wall. Comparison with $\mathrm{N}$-propargylated ciprofloxacin showed, that alkylation of the secondary amine of the piperazine ring already resulted in a decreased antibiotic activity. Further, we proved the inhibition of gyrase-catalyzed DNA supercoiling as the conjugates' antimicrobial mode of action.

In the first $P$. aeruginosa biofilm accumulation assay, we observed an enrichment of lectin-targeting conjugates compared to ciprofloxacin, which could compensate for the decrease in antimicrobial activity. Since cytotoxicity of both conjugates was decreased compared to ciprofloxacin especially against kidney cells, and the biofilm accumulation was achieved, a reduction of the severe systemic side effects of ciprofloxacin is possible. Further, in vitro metabolism assays showed good metabolic stability supporting the conjugates' design as $S$ - or $C$-glycosides.

This work reports the first $P$. aeruginosa biofilm-targeted antibiotics and analyzes their properties on lectin binding, antimicrobial activity, target inhibition, and biofilm enrichment. In vitro studies revealed a reduced cytotoxicity of the conjugates compared to the parent drug ciprofloxacin. Future work will address the improvement of antimicrobial activity of the antibiotic conjugates. Our modular synthesis allows the conjugation of lectin probes to other antibiotics, leading to future generations of biofilm targeting antibiotics. 


\section{EXPERIMENTAL SECTION}

Chemical Synthesis. Thin layer chromatography (TLC) was performed on Silica Gel 60 coated aluminum sheets containing a fluorescence indicator (Merck KGaA, Darmstadt, Germany) and developed under UV light $(254 \mathrm{~nm})$ and aqueous $\mathrm{KMnO}_{4}$ solution or a molybdate solution (a $0.02 \mathrm{M}$ solution of ammonium cerium sulfate dihydrate and ammonium molybdate tetrahydrate in aqueous $10 \%$ $\mathrm{H}_{2} \mathrm{SO}_{4}$ ). Self-packed Silica Gel 60 columns (60 A, 400 mesh particle size, Fluka, for normal-phase liquid chromatography) or Chromabond Flash RS15 $\mathrm{C}_{18}$ ec columns (Macherey-Nagel, Düren, Germany, for reversed-phase liquid chromatography), and a Teledyne Isco Combiflash Rf200 system were used for preparative medium pressure liquid chromatography (MPLC). Nuclear magnetic resonance (NMR) spectroscopy was performed on a Bruker Avance III 500 UltraShield spectrometer at $500 \mathrm{MHz}\left({ }^{1} \mathrm{H}\right)$ or $126 \mathrm{MHz}\left({ }^{13} \mathrm{C}\right)$. Chemical shifts are given in parts per million (ppm) and were calibrated on residual solvent peaks as an internal standard. Multiplicities were specified as s (singlet), $\mathrm{d}$ (doublet), $\mathrm{t}$ (triplet), $\mathrm{q}$ (quartet), or $\mathrm{m}$ (multiplet). The signals were assigned with the help of ${ }^{1} \mathrm{H},{ }^{1} \mathrm{H}$ COSY, and DEPT-135-edited ${ }^{1} \mathrm{H},{ }^{13} \mathrm{C}$ HSQC experiments. Assignment numbering of the $C$-glycoside atoms and groups corresponds to the numbering in fucose. Assignment numbering of the galactoside atoms and groups corresponds to the numbering in galactose. Assignment numbering of the ciprofloxacin atoms and groups corresponds to the numbering in ciprofloxacin (cipro). ${ }^{70}$ Commercial chemicals and solvents were used without further purification. Deuterated solvents were purchased from Eurisotop (Saarbrücken, Germany). Ciprofloxacin and polymyxin B nonapeptide. $\mathrm{HCl}(\mathrm{PMBN})$ was purchased from Sigma-Aldrich (purity $\geq 98 \%$, HPLC, Merck KGaA, Darmstadt, Germany), and ciprofloxacin $\cdot \mathrm{HCl}$ was purchased from Cayman Chemical (Ann Arbor, Michigan, USA). If not stated otherwise, the purity of the final compounds was further analyzed by HPLC-UV, and all UV active compounds had a purity of at least $95 \%$. Chromatographic separation was performed on a Dionex Ultimate 3000 HPLC (Thermo Scientific, Germany) with UV detection at $254 \mathrm{~nm}$ using a RP-18 column (100/ 2 Nucleoshell RP18plus, $2.7 \mu \mathrm{m}$, from Macherey-Nagel, Germany) as a stationary phase. LCMS-grade distilled $\mathrm{MeCN}$ and double distilled $\mathrm{H}_{2} \mathrm{O}$ were used as mobile phases containing formic acid $(0.1 \% \mathrm{v} / \mathrm{v})$. In a gradient run, an initial concentration of $5 \% \mathrm{MeCN}$ in $\mathrm{H}_{2} \mathrm{O}$ was increased to $95 \%$ during $7 \mathrm{~min}$ at a flow rate $600 \mu \mathrm{L} / \mathrm{min}$. The injection volume was $4 \mu \mathrm{L}$ of $1 \mathrm{mM}$ compound in $\mathrm{H}_{2} \mathrm{O} / \mathrm{DMSO}=$ 100:1. UPLC-HRMS for key compounds were obtained using a RP18 column (EC 150/2 Nucleodur C18 Pyramid, $3 \mu \mathrm{m}$, from Macharey-Nagel, Germany) and a Q Exactive Focus Orbitrap spectrometer (Thermo Scientific, Germany). The data was analyzed using Xcalibur data acquisition and interpretation software (Thermo Scientific, Germany).

General procedure (i) for amide couplings of 6: Aniline 6 and $\mathrm{K}_{2} \mathrm{CO}_{3}$ (2 eq.) were dispersed in dry DCM $(0.1 \mathrm{M})$ and cooled $(0$ $\left.{ }^{\circ} \mathrm{C}\right)$. The corresponding $(\omega$-bromo)acylhalide was added dropwise under vigorous stirring. After stirring for $15 \mathrm{~min}$, the reaction was allowed to warm to r.t. and stirred for 1-4 h until full conversion as monitored by TLC (PE:EtOAc) or HPLC-MS. The reaction was quenched with ice-cold water. The organic phase was washed with brine, and combined organic layers were dried over anhydrous $\mathrm{Na}_{2} \mathrm{SO}_{4}$. After filtration, the solvent was evaporated in vacuo.

General procedure (ii) for $\mathrm{S}_{\mathrm{N}} 2$ reactions with $\mathrm{NaN}_{3}$ toward 7-10: The crude starting material was dissolved in dry DMF (0.1 M). A 5 eq. solution of $\mathrm{NaN}_{3}$ was added, and the reaction was stirred at r.t. until completion (monitored by HPLC-MS). Then, the reaction was diluted with an excess of water and extracted with EtOAc (3x). The combined organic layers were washed with half satd. brine and dried over anhydrous $\mathrm{Na}_{2} \mathrm{SO}_{4}$. After filtration, the solvent was evaporated in vacuo and the products were purified by MPLC (PE:EtOAc, 30$80 \%)$.

General procedure (iii) for the Zemplén deprotection of 7-10: The starting material was suspended in dry $\mathrm{MeOH}(0.1 \mathrm{M})$ and a freshly prepared solution of $\mathrm{NaOMe}$ in $\mathrm{MeOH}(1 \mathrm{M})$ was added dropwise to $10 \mathrm{~mol} \%$. The reaction was stirred for $1-2 \mathrm{~h}$ until the disappearance of the starting material, monitored by TLC (PE:EtOAc, 4:6). Then, the reaction was diluted with $\mathrm{MeOH}$ and neutralized with Amberlite IR-120 $\mathrm{H}^{+}$exchange resin. The resin was filtered off, and the solvent was evaporated in vacuo. Purification was performed by reversed-phase MPLC ( $\mathrm{MeCN}: \mathrm{H}_{2} \mathrm{O}, 10-20 \%, 0.1 \%$ formic acid). The solvent was removed by lyophilization.

General procedure (iv) for the copper-catalyzed click reaction toward conjugates 22-31: Alkyne (1.1 eq.) and azide (1 eq.) were dissolved in $1 \mathrm{~mL}$ of dry DMF (purged with argon). $\mathrm{CuSO}_{4} \cdot 7 \mathrm{H}_{2} \mathrm{O}$ $(10 \mathrm{~mol} \%)$ and sodium ascorbate $(20 \mathrm{~mol} \%)$ were added as aqueous solutions from freshly prepared stock solutions $(100 \mathrm{mM})$. The mixture was stirred at r.t. or $40{ }^{\circ} \mathrm{C}$ for $16-24 \mathrm{~h}$. Reaction progress was monitored by HPLC-MS. After full conversion, the solvents were evaporated in vacuo followed by purification via RP-MPLC ( $\mathrm{MeCN}: \mathrm{H}_{2} \mathrm{O}, 10-20 \%, 0.1 \%$ formic acid). The solvent was removed by lyophilization.

p-Nitrophenyl 2,3,4,6-Tetra-O-acetyl- $\beta$-D-thiogalactopyranoside (5). Galactose pentaacetate $(4,2.0 \mathrm{~g}, 5.1 \mathrm{mmol}, 1 \mathrm{eq}$. $)$ and $p$ nitrothiophenol ( $2.4 \mathrm{~g}, 15.3 \mathrm{mmol}, 3 \mathrm{eq}$.) were dissolved in $20 \mathrm{~mL}$ dry $\mathrm{CH}_{2} \mathrm{Cl}_{2}$ in a heat-dried flask under a $\mathrm{N}_{2}$ atmosphere. The mixture was cooled $\left(0{ }^{\circ} \mathrm{C}\right)$, and $\mathrm{BF}_{3} \cdot \mathrm{Et}_{2} \mathrm{O}(3.2 \mathrm{~mL}, 25.5 \mathrm{mmol}, 5$ eq.) was added dropwise under vigorous stirring. Afterward, the reaction was allowed to warm to r.t. and stirred overnight $(17 \mathrm{~h})$. Reaction progress was monitored by TLC (Tol:EtOAc, 9:1). After consumption of the starting material, the reaction was poured on ice water. The organic phase was isolated and washed with aq. satd. $\mathrm{NaHCO}_{3}$. The combined organic layers were washed with half satd. brine and dried over anhydrous $\mathrm{Na}_{2} \mathrm{SO}_{4}$. After filtration, the solvent was removed in vacuo. Purification by MPLC $\left(\mathrm{SiO}_{2}, \mathrm{EtOAc}\right.$ in toluene, 5$20 \%)$ gave the product as a pale yellow amorphous solid (1.3 g, 51\%). ${ }^{1} \mathrm{H}$ NMR $\left(500 \mathrm{MHz}, \mathrm{CHCl}_{3}-d\right) \delta 8.16(\mathrm{~d}, J=8.8 \mathrm{~Hz}, 2 \mathrm{H}, \mathrm{Ar}-\mathrm{H})$, $7.61(\mathrm{~d}, J=8.8 \mathrm{~Hz}, 2 \mathrm{H}, \mathrm{Ar}-\mathrm{H}), 5.47(\mathrm{~d}, J=3.2 \mathrm{~Hz}, 1 \mathrm{H}$, glyco-H-4), $5.29(\mathrm{t}, J=10.0 \mathrm{~Hz}, 1 \mathrm{H}$, glyco-H-2), $5.10(\mathrm{dd}, J=9.9,3.3 \mathrm{~Hz}, 1 \mathrm{H}$, glyco-H-3), $4.86(\mathrm{~d}, J=10.0 \mathrm{~Hz}, 1 \mathrm{H}$, glyco-H-1), 4.21 (dd, $J=11.5$, $7.2 \mathrm{~Hz}, 1 \mathrm{H}$, glyco-H-6), 4.14 (dd, $J=11.5,5.8 \mathrm{~Hz}, 1 \mathrm{H}$, glyco-H-6'), $4.04\left(\mathrm{t}, J=6.5 \mathrm{~Hz}, 1 \mathrm{H}\right.$, glyco-H-5), $2.35\left(\mathrm{~s}, 3 \mathrm{H}, \mathrm{Ac}-\mathrm{CH}_{3}\right), 2.16(\mathrm{~s}$, $\left.3 \mathrm{H}, \mathrm{Ac}-\mathrm{CH}_{3}\right), 2.09\left(\mathrm{~s}, 3 \mathrm{H}, \mathrm{Ac}-\mathrm{CH}_{3}\right), 2.08\left(\mathrm{~s}, 3 \mathrm{H}, \mathrm{Ac}-\mathrm{CH}_{3}\right), 1.99$ (s, $\left.3 \mathrm{H}, \mathrm{Ac}-\mathrm{CH}_{3}\right) ;{ }^{13} \mathrm{C} \mathrm{NMR}\left(126 \mathrm{MHz}, \mathrm{CHCl}_{3}-d\right) \delta 170.44(\mathrm{C}=$ $\mathrm{O}), 170.15(\mathrm{C}=\mathrm{O}), 170.08(\mathrm{C}=\mathrm{O}), 169.50(\mathrm{C}=\mathrm{O}), 146.96(\mathrm{Ar}-$ C), 142.52 ( $\mathrm{Ar}-\mathrm{C}), 130.52(\mathrm{Ar}-\mathrm{C}), 123.97$ (Ar-C), 84.97 (glyco-C1), 74.97 (glyco-C-5), 71.85 (glyco-C-3), 67.20 (glyco-C-4), 66.84 (glyco-C-2), 61.81 (glyco-C-6), $20.88\left(\mathrm{Ac}-\mathrm{CH}_{3}\right), 20.84\left(\mathrm{Ac}-\underline{\mathrm{CH}}_{3}\right)$, $20.79\left(\mathrm{Ac}-\mathrm{CH}_{3}\right), 20.68\left(\mathrm{Ac}-\mathrm{CH}_{3}\right)$. LR-MS: $m / z=503.16,[\mathrm{M}+$ $\mathrm{Na}]^{+}$. Spectroscopic data is in accordance with the literature. ${ }^{7}$

p-Aminophenyl 2,3,4,6-Tetra-O-acetyl- $\beta$-D-thiogalactopyranoside (6). Compound $\mathbf{6}$ was synthesized according to Casoni et al.: ${ }^{66}$ $p$-nitrophenyl 2,3,4,6-tetra- $O$-acetyl- $\beta$-D-galactothiopyranoside $(5,1.0$ $\mathrm{g}, 2.06 \mathrm{mmol}, 1$ eq.) was dissolved in $70 \mathrm{~mL}$ of dry DCM and $\mathrm{Pd} / \mathrm{C}$ (50 mg, $5 \mathrm{wt} \%$ ) was added. The reaction vessel was flushed several times with hydrogen and subsequently stirred under a hydrogen atmosphere $(1 \mathrm{bar})$ for $48 \mathrm{~h}$. The reaction was followed by TLC (PE:EtOAc, 1:1). After completion, the reaction was filtered over celite. The solvent was removed in vacuo, and the pure product was obtained as a pink amorphous solid (903 mg, 96\%), which was used without further purification in the next step. ${ }^{1} \mathrm{H}$ NMR $(500 \mathrm{MHz}$, DMSO- $\left.d_{6}\right) \delta 7.18-7.08(\mathrm{~m}, 2 \mathrm{H}, \mathrm{ArH}), 6.57-6.48(\mathrm{~m}, 2 \mathrm{H}, \mathrm{ArH})$, $5.39\left(\mathrm{~s}, 2 \mathrm{H}, \mathrm{NH}_{2}\right), 5.25(\mathrm{dd}, J=3.5,1.0 \mathrm{~Hz}, 1 \mathrm{H}$, glyco-H-4), 5.18 (dd, $J=9.7,3.5 \mathrm{~Hz}, 1 \mathrm{H}$, glyco-H-3), $4.93(\mathrm{t}, J=9.9 \mathrm{~Hz}, 1 \mathrm{H}$, glyco-H2), $4.78(\mathrm{~d}, J=10.0 \mathrm{~Hz}, 1 \mathrm{H}$, glyco-H-1), $4.21-4.13(\mathrm{~m}, 1 \mathrm{H}$, glyco-H5), 4.11-3.93 (m, 2H, glyco-H-6), $2.09\left(\mathrm{~s}, 3 \mathrm{H}, \mathrm{Ac}^{-\mathrm{CH}_{3}}\right), 2.06(\mathrm{~s}, 3 \mathrm{H}$, $\left.\mathrm{Ac}-\mathrm{CH}_{3}\right), 2.00\left(\mathrm{~s}, 3 \mathrm{H}, \mathrm{Ac}-\mathrm{CH}_{3}\right), 1.90\left(\mathrm{~s}, 3 \mathrm{H}, \mathrm{Ac}-\mathrm{CH}_{3}\right) .{ }^{13} \mathrm{C} \mathrm{NMR}$ $\left(126 \mathrm{MHz}, \mathrm{DMSO}-d_{6}\right) \delta 169.93(\mathrm{C}=\mathrm{O}), 169.84(\mathrm{C}=\mathrm{O}), 169.46$ $(\mathrm{C}=\mathrm{O}), 169.17(\mathrm{C}=\mathrm{O}), 149.42(\mathrm{ArC}), 135.15(\mathrm{ArC}), 115.20$ (ArC), 114.07 (ArC), 86.07 (glyco-C-1), 73.25 (glyco-C-5), 71.20 (glyco-C-3), 67.62 (glyco-C-4), 67.24 (glyco-C-2), 61.66 (glyco-C-6), $20.63\left(\mathrm{Ac}-\mathrm{CH}_{3}\right), 20.51\left(\mathrm{Ac}-\underline{\mathrm{CH}}_{3}\right), 20.40\left(\mathrm{Ac}-\underline{\mathrm{CH}}_{3}\right), 20.36(\mathrm{Ac}-$ $\left.\mathrm{CH}_{3}\right)$. LR-MS: $m / z=456.2,[\mathrm{M}+\mathrm{H}]^{+}$.

$p$-( $\alpha$-Azidoacetamido)phenyl 2,3,4,6-Tetra-O-acetyl- $\beta$ - $D$-thiogalactopyranoside (7). 7 was synthesized starting from 6 in two 
chemical steps in analogy to Casoni et al.: ${ }^{66}$ Aniline 6 (300 mg, 0.66 mmol, 1 eq.) and triethylamine (140 $\mu \mathrm{L}, 1.01 \mathrm{mmol}, 1.6$ eq.) were dissolved in $6 \mathrm{~mL}$ of dry DCM. The solution was cooled $\left(0{ }^{\circ} \mathrm{C}\right)$, and bromoacetylbromide ( $86 \mu \mathrm{L}, 0.99 \mathrm{mmol}, 1.5$ eq. $)$ was added dropwise under vigorous stirring. The reaction was stirred for $1 \mathrm{~h}$ followed by TLC (PE:EtOAc, 7:3). After completion, the mixture was quenched with ice water. The organic phase was washed with aq. satd. $\mathrm{NH}_{4} \mathrm{Cl}$ $(3 \mathrm{x})$, water $(2 \mathrm{x})$, and brine $(1 \mathrm{x})$ and dried over anhydrous $\mathrm{Na}_{2} \mathrm{SO}_{4}$. After filtration, the solvent was removed in vacuo to yield the crude intermediate as an oil (370 mg), which was transformed according to general procedure ii. Product 7 was obtained as a white amorphous solid (283.2 mg, 80\% over two steps). ${ }^{1} \mathrm{H}$ NMR in accordance with the literature ${ }^{66}\left(500 \mathrm{MHz}, \mathrm{CHCl}_{3}-d\right) \delta 8.04(\mathrm{~s}, 1 \mathrm{H}$, Amide-NH), 7.52 (s, $4 \mathrm{H}, \operatorname{ArH}), 5.41(\mathrm{~d}, J=3.0 \mathrm{~Hz}, 1 \mathrm{H}$, glyco-H-4), $5.20(\mathrm{t}, J=9.9 \mathrm{~Hz}$, $1 \mathrm{H}$, glyco-H-2), 5.04 (dd, $J=9.9,3.3 \mathrm{~Hz}, 1 \mathrm{H}$, glyco-H-3), 4.65 (d, $J=$ $10.0 \mathrm{~Hz}, 1 \mathrm{H}$, glyco-H-1), 4.18 (dd, $J=11.3 \mathrm{~Hz}$, overlaps with 4.16 , $1 \mathrm{H}$, glyco-H-6), $4.16\left(\mathrm{~s}, 2 \mathrm{H}, \mathrm{CH}_{2} \mathrm{~N}_{3}\right), 4.11(\mathrm{dd}, J=11.3,6.3 \mathrm{~Hz}, 1 \mathrm{H}$, glyco-H-6'), $3.92(\mathrm{t}, J=6.6 \mathrm{~Hz}, 1 \mathrm{H}$, glyco-H-5), $2.12(\mathrm{~s}, 3 \mathrm{H}, \mathrm{Ac}-$ $\left.\mathrm{CH}_{3}\right), 2.10\left(\mathrm{~s}, 3 \mathrm{H}, \mathrm{Ac}-\mathrm{CH}_{3}\right), 2.05\left(\mathrm{~s}, 3 \mathrm{H}, \mathrm{Ac}-\mathrm{CH}_{3}\right), 1.97$ (s, 3H, Ac$\left.\mathrm{CH}_{3}\right) \cdot{ }^{13} \mathrm{C}$ NMR (126 MHz, $\left.\mathrm{CHCl}_{3}-d\right) \delta 170.54(\mathrm{C}=\mathrm{O}), 170.33$ $(\mathrm{C}=\mathrm{O}), 170.20(\mathrm{C}=\mathrm{O}), 169.55(\mathrm{C}=\mathrm{O}), 164.64(\mathrm{C}=\mathrm{O}), 137.21$ (ArC), 134.29 (ArC), 128.05 ( $\mathrm{ArC}), 120.34$ (ArC), 86.79 (glyco-C1), 74.60 (glyco-C-5), 72.12 (glyco-C-3), 67.32 (glyco-C-4), 61.72 (glyco-C-2), 53.11 (glyco-C-6), $53.07 \quad\left(\mathrm{CH}_{2} \mathrm{~N}_{3}\right.$, extracted from HSQC $), 21.01\left(\mathrm{Ac}-\underline{\mathrm{CH}}_{3}\right), 20.85\left(\mathrm{Ac}-\underline{\mathrm{CH}}_{3}\right), 20.81\left(\mathrm{Ac}-\underline{\mathrm{C}} \mathrm{H}_{3}\right)$, $20.73\left(\mathrm{Ac}-\mathrm{CH}_{3}\right)$. LR-MS: $m / z=539.1,[\mathrm{M}+\mathrm{H}]^{+}$.

$p$-( $\beta$-Azidopropamido)phenyl 2,3,4,6-Tetra-O-acetyl- $\beta$ - $D$-thiogalactopyranoside (8). The title compound was synthesized starting from $6(300 \mathrm{mg}, 0.66 \mathrm{mmol}, 1$ eq.) according to general procedures $\mathrm{i}$ and ii and was obtained as a white amorphous solid over two chemical steps $(316 \mathrm{mg}, 87 \%)$. However, the elimination product could not be separated, resulting in a $<10 \%$ contamination of the corresponding Michael-acceptor side product (quantified by ${ }^{1} \mathrm{H}$ NMR). ${ }^{1} \mathrm{H}$ NMR $\left(500 \mathrm{MHz}, \mathrm{CHCl}_{3}-d\right) \delta 7.49(\mathrm{~s}, 4 \mathrm{H}, \mathrm{ArH}), 7.44(\mathrm{~s}, 1 \mathrm{H}, \mathrm{NH}), 6.44(\mathrm{~d}$, $J=16.9 \mathrm{~Hz}, 1 \mathrm{H},-\mathrm{COCH} \mathrm{CH}_{2}$, from impurity), 6.24 (dd, $J=16.8$, $10.3 \mathrm{~Hz}, 1 \mathrm{H},-\mathrm{COCHCH}-\mathrm{H}$, from impurity), $5.80(\mathrm{~d}, J=10.2 \mathrm{~Hz}$, $1 \mathrm{H},-\mathrm{COCHCH}-\mathrm{H}^{\prime}$, from impurity), $5.40(\mathrm{~d}, J=3.1 \mathrm{~Hz}, 1 \mathrm{H}$, glyco$\mathrm{H}-4), 5.19(\mathrm{t}, J=9.9 \mathrm{~Hz}, 1 \mathrm{H}$, glyco-H-2), $5.03(\mathrm{dd}, J=9.9,3.1 \mathrm{~Hz}$, $1 \mathrm{H}$, glyco-H-3), $4.63(\mathrm{~d}, J=9.9 \mathrm{~Hz}, 1 \mathrm{H}$, glyco-H-1), $4.17(\mathrm{dd}, J=$ $11.3,6.9 \mathrm{~Hz}, 1 \mathrm{H}$, glyco-H-6), 4.10 (dd, $J=11.5,6.3 \mathrm{~Hz}, 1 \mathrm{H}$, glyco-H$\left.6^{\prime}\right), 3.90(\mathrm{t}, J=6.5 \mathrm{~Hz}, 1 \mathrm{H}$, glyco-H-5), $3.72(\mathrm{t}, J=6.2 \mathrm{~Hz}, 2 \mathrm{H}$, $\left.\mathrm{CO} \underline{\mathrm{CH}}_{2}\right), 2.60\left(\mathrm{t}, J=6.2 \mathrm{~Hz}, 2 \mathrm{H}, \underline{\mathrm{CH}}_{2} \mathrm{~N}_{3}\right), 2.11\left(\mathrm{~s}, 3 \mathrm{H}, \mathrm{Ac}-\mathrm{CH}_{3}\right)$, $2.10\left(\mathrm{~s}, 3 \mathrm{H}, \mathrm{Ac}-\mathrm{CH}_{3}\right), 2.05\left(\mathrm{~s}, 3 \mathrm{H}, \mathrm{Ac}-\mathrm{CH}_{3}\right), 1.97(\mathrm{~s}, 3 \mathrm{H}, \mathrm{Ac}-$ $\left.\mathrm{CH}_{3}\right) \cdot{ }^{13} \mathrm{C}$ NMR $\left(126 \mathrm{MHz}, \mathrm{CHCl}_{3}-d\right) \delta 170.45(\mathrm{C}=\mathrm{O}), 170.25$ $(\mathrm{C}=\mathrm{O}), 170.10(\mathrm{C}=\mathrm{O}), 169.48(\mathrm{C}=\mathrm{O}), 168.22(\mathrm{C}=\mathrm{O}), 137.92$ (ArC), 134.23 (ArC), 127.27 ( $\mathrm{ArC}), 120.14$ (ArC), 86.78 (glyco-C1), 74.43 (glyco-C-5), 72.00 (glyco-C-3), 67.24 (glyco-C-4), 67.20 (glyco-C-2), 61.58 (glyco-C-6), $47.24\left(\mathrm{COC}_{2} \mathrm{CH}_{2} \mathrm{~N}_{3}\right), 36.96$ $\left(\mathrm{COCH}_{2} \mathrm{CH}_{2} \mathrm{~N}_{3}\right), 20.88\left(\mathrm{Ac}-\underline{\mathrm{C}} \mathrm{H}_{3}\right), 20.72\left(\mathrm{Ac}-\mathrm{CH}_{3}\right), 20.67$ (Ac$\left.\mathrm{CH}_{3}\right), 20.60\left(\mathrm{Ac}^{-} \mathrm{CH}_{3}\right)$. LR-MS: $m / z=553.1,[\mathrm{M}+\mathrm{H}]^{+}$.

$p$-( $\gamma$-Azidobutyramido)phenyl 2,3,4,6-Tetra-O-acetyl- $\beta$-D-thiogalactopyranoside (9). The title compound was synthesized starting from $6(300 \mathrm{mg}, 0.66 \mathrm{mmol}, 1$ eq.) according to general procedures $i$ and ii and was obtained as a white amorphous solid over two chemical steps $(296 \mathrm{mg}, 79 \%) .{ }^{1} \mathrm{H}$ NMR $\left(500 \mathrm{MHz}, \mathrm{CHCl}_{3}-d\right) \delta 7.48(\mathrm{~s}, 4 \mathrm{H}$, $\mathrm{Ar}-\mathrm{H}), 7.44(\mathrm{~s}, 1 \mathrm{H}, \mathrm{NH}), 5.40(\mathrm{~d}, J=3.4 \mathrm{~Hz}, 1 \mathrm{H}$, glyco-H-4), 5.20 $(\mathrm{t}, J=9.9 \mathrm{~Hz}, 1 \mathrm{H}$, glyco-H-2), $5.02(\mathrm{dd}, J=10.0,3.3 \mathrm{~Hz}, 1 \mathrm{H}$, glyco$\mathrm{H}-3), 4.62(\mathrm{~d}, J=9.9 \mathrm{~Hz}, 1 \mathrm{H}$, glyco-H-1), $4.17(\mathrm{dd}, J=11.3,6.9 \mathrm{~Hz}$, $1 \mathrm{H}$, glyco-H-6), 4.09 (dd, $J=11.3,6.3 \mathrm{~Hz}, 1 \mathrm{H}$, glyco-H- $\left.6^{\prime}\right), 3.90(\mathrm{t}, J$ $=6.6 \mathrm{~Hz}, 1 \mathrm{H}$, glyco-H-5), $3.41\left(\mathrm{t}, J=6.4 \mathrm{~Hz}, 2 \mathrm{H}, \mathrm{COCH}_{2}\right), 2.47(\mathrm{t}, J$ $\left.=7.1 \mathrm{~Hz}, 2 \mathrm{H}, \mathrm{CH}_{2} \mathrm{~N}_{3}\right), 2.12\left(\mathrm{~s}, 3 \mathrm{H}, \mathrm{Ac}-\mathrm{CH}_{3}\right), 2.10\left(\mathrm{~s}, 3 \mathrm{H}, \mathrm{Ac}-\mathrm{CH}_{3}\right)$, $2.04\left(\mathrm{~s}, 3 \mathrm{H}, \mathrm{Ac}-\mathrm{CH}_{3}\right), 2.00\left(\mathrm{t}, J=6.8 \mathrm{~Hz}, 2 \mathrm{H},-\underline{\mathrm{CH}}_{2}-\right), 1.97(\mathrm{~s}, 3 \mathrm{H}$, $\left.\mathrm{Ac}-\mathrm{CH}_{3}\right) .{ }^{13} \mathrm{C} \mathrm{NMR}\left(126 \mathrm{MHz}, \mathrm{CHCl}_{3}-d\right) \delta 170.57(\mathrm{C}=\mathrm{O}), 170.35$ $(\mathrm{C}=\mathrm{O}), 170.26(\mathrm{C}=\mathrm{O}), 170.21(\mathrm{C}=\mathrm{O}), 169.61(\mathrm{C}=\mathrm{O}), 138.25$ $(\mathrm{ArC}), 134.31$ (ArC), 127.14 (ArC), 120.11 (ArC), 86.95 (glyco-C1), 74.52 (glyco-C-5), 72.10 (glyco-C-3), 67.36 (glyco-C-4), 67.32 (glyco-C-2), 61.68 (glyco-C-6), $50.78\left(\mathrm{COCH}_{2}\right), 34.26\left(\mathrm{CH}_{2} \mathrm{~N}_{3}\right)$, $24.66\left(\mathrm{CH}_{2}\right), 20.99\left(\mathrm{Ac}-\mathrm{CH}_{3}\right), 20.82\left(\mathrm{Ac}-\mathrm{CH}_{3}\right), 20.77\left(\mathrm{Ac}-\mathrm{CH}_{3}\right)$, $20.71\left(\mathrm{Ac}-\mathrm{CH}_{3}\right)$. LR-MS: $m / z=567.1,[\mathrm{M}+\mathrm{H}]^{+}$. p-( $\delta$-Azidovalerylamido)phenyl 2,3,4,6-Tetra-O-acetyl- $\beta$-D-thiogalactopyranoside (10). The title compound was synthesized starting from 6 (300 mg, $0.66 \mathrm{mmol}, 1$ eq.) according to general procedures $i$ and ii and was obtained as a white amorphous solid over two chemical steps ( $327 \mathrm{mg}, 85 \%)$. 1H NMR (500 MHz, $\left.\mathrm{CHCl}_{3}-d\right) \delta$ $7.48(\mathrm{~s}, 4 \mathrm{H}, \mathrm{Ar}-\mathrm{H}), 7.24(\mathrm{~s}, 1 \mathrm{H}, \mathrm{NH}), 5.40(\mathrm{~d}, J=3.2 \mathrm{~Hz}, 1 \mathrm{H}$, glyco$\mathrm{H}-4), 5.19(\mathrm{t}, J=9.9 \mathrm{~Hz}, 1 \mathrm{H}$, glyco-H-2), $5.03(\mathrm{dd}, J=9.9,3.3 \mathrm{~Hz}$, $1 \mathrm{H}$, glyco-H-3), $4.63(\mathrm{~d}, J=10.0 \mathrm{~Hz}, 1 \mathrm{H}$, glyco-H-1), 4.17 (dd, $J=$ $11.3,6.9 \mathrm{~Hz}, 1 \mathrm{H}$, glyco-H-6), 4.10 (dd, $J=11.3,6.3 \mathrm{~Hz}, 1 \mathrm{H}$, glyco-H$\left.6^{\prime}\right), 3.90(\mathrm{t}, J=6.6 \mathrm{~Hz}, 1 \mathrm{H}$, glyco-H-5), $3.34(\mathrm{t}, J=6.7 \mathrm{~Hz}, 2 \mathrm{H}$, $\left.-\mathrm{COCH}_{2}-\right), 2.41\left(\mathrm{t}, J=7.3 \mathrm{~Hz}, 2 \mathrm{H},-\mathrm{CH}_{2} \mathrm{~N}_{3}\right), 2.11(\mathrm{~s}, 3 \mathrm{H}, \mathrm{Ac}-$ $\left.\mathrm{CH}_{3}\right), 2.10\left(\mathrm{~s}, 3 \mathrm{H}, \mathrm{Ac}-\mathrm{CH}_{3}\right), 2.05\left(\mathrm{~s}, 3 \mathrm{H}, \mathrm{Ac}-\mathrm{CH}_{3}\right), 1.97(\mathrm{~s}, 3 \mathrm{H}$, $\left.\mathrm{Ac}-\mathrm{CH}_{3}\right), 1.82\left(\mathrm{p}, J=7.4 \mathrm{~Hz}, 2 \mathrm{H},-\mathrm{CH}_{2} \mathrm{CH}_{2} \mathrm{~N}_{3}\right), 1.74-1.64(\mathrm{p}, 2 \mathrm{H}$, $\left.-\mathrm{COCH}_{2} \mathrm{CH}_{2}-\right) .{ }^{13} \mathrm{C}$ NMR $\left(126 \mathrm{MHz}, \mathrm{CHCl}_{3}-d\right) \delta 170.69(\mathrm{C}=\mathrm{O})$, $170.56(\mathrm{C}=\mathrm{O}), 170.36(\mathrm{C}=\mathrm{O}), 170.21(\mathrm{C}=\mathrm{O}), 169.59(\mathrm{C}=\mathrm{O})$, 138.34 (ArC), 134.39 (ArC), 127.03 (ArC), 120.05 (ArC), 86.99 (glyco-C-1), 74.55 (glyco-C-5), 72.13 (glyco-C-3), 67.37 (glyco-C-4), 67.33 (glyco-C-2), 61.70 (glyco-C-6), $51.31\left(\mathrm{CO}-\mathrm{CH}_{2}-\right), 37.07$ $\left(-\mathrm{CH}_{2}-\mathrm{N}_{3}\right), 28.43\left(-\mathrm{COCH}_{2} \mathrm{CH}_{2}-\right), 22.75\left(-\mathrm{CH}_{2} \mathrm{CH}_{2} \mathrm{~N}_{3}\right), 21.01$ $\left(\mathrm{Ac}-\mathrm{CH}_{3}\right), 20.85\left(\mathrm{Ac}-\underline{\mathrm{CH}}_{3}\right), 20.80\left(\mathrm{Ac}-\underline{\mathrm{CH}}_{3}\right), 20.72\left(\mathrm{Ac}-\underline{\mathrm{CH}}_{3}\right)$. LR-MS: $m / z=581.2,[\mathrm{M}+\mathrm{H}]^{+}$.

$p$-( $\alpha$-Azidoacetamido)phenyl- $\beta$-D-thiogalactopyranoside (11). The title compound was synthesized from $7(275 \mathrm{mg}, 0.51 \mathrm{mmol}$, 1 eq.) according to general procedure iii and was obtained as a white solid $(142 \mathrm{mg}, 75 \%) .{ }^{1} \mathrm{H}$ NMR $\left(500 \mathrm{MHz}, \mathrm{MeOH}-d_{4}\right) \delta 7.54(\mathrm{~s}, 4 \mathrm{H}$, $\mathrm{ArH}), 4.51\left(\mathrm{~d}, J=9.7 \mathrm{~Hz}, 1 \mathrm{H}\right.$, glyco-H-1), $4.01\left(\mathrm{~s}, 2 \mathrm{H},-\mathrm{CH}_{2} \mathrm{~N}_{3}\right), 3.89$ $(\mathrm{d}, J=3.2 \mathrm{~Hz}, 1 \mathrm{H}$, glyco-H-4), $3.76(\mathrm{dd}, J=11.5,6.8 \mathrm{~Hz}, 1 \mathrm{H}$, glycoH-6), 3.70 (dd, $J=11.5,5.2 \mathrm{~Hz}, 1 \mathrm{H}$, glyco-H-6'), 3.62-3.52 (m, $2 \mathrm{H}$, glyco-H-2 + glyco-H-5), 3.49 (dd, $J=9.2,3.3 \mathrm{~Hz}, 1 \mathrm{H}$, glyco-H-3). ${ }^{13} \mathrm{C}$ NMR $\left(126 \mathrm{MHz}, \mathrm{MeOH}-d_{4}\right) \delta 168.47(\mathrm{C}=\mathrm{O}), 138.61(\mathrm{ArC})$, 133.58 (ArC), 130.91 (ArC), 121.59 (ArC), 90.50 (glyco-C-1), 80.61 (glyco-C-5), 76.30 (glyco-C-3), 70.93 (glyco-C-2), 70.40 (glyco-C-4), 62.60 (glyco-C-6), $53.26\left(-\underline{\mathrm{CH}}_{2} \mathrm{~N}_{3}\right)$. HR-MS calcd $\left[\mathrm{C}_{14} \mathrm{H}_{17} \mathrm{~N}_{4} \mathrm{O}_{6} \mathrm{~S}\right]^{-}$: 369.0874 , found 369.0877 .

$p$-( $\beta$-Azidopropamido)phenyl- $\beta$-D-thiogalactopyranoside (12). The title compound was synthesized from $8(309 \mathrm{mg}, 0.56 \mathrm{mmol}$, 1 eq.) according to general procedure iii and was obtained as a white solid $(216 \mathrm{mg}, 54 \%) .{ }^{1} \mathrm{H}$ NMR $\left(500 \mathrm{MHz}, \mathrm{MeOH}-d_{4}\right) \delta 7.53$ (d, $J=$ $1.1 \mathrm{~Hz}, 4 \mathrm{H}, \mathrm{ArH}), 4.50(\mathrm{~d}, J=9.6 \mathrm{~Hz}, 1 \mathrm{H}$, glyco-H-1), $3.88(\mathrm{~d}, J=2.5$ $\mathrm{Hz}, 1 \mathrm{H}$, glyco-H-4), 3.76 (dd, $J=11.5,6.8 \mathrm{~Hz}, 1 \mathrm{H}$, glyco-H-6), 3.70 $\left(\mathrm{dd}, J=11.5,5.3 \mathrm{~Hz}, 1 \mathrm{H}\right.$, glyco-H- $\left.6^{\prime}\right), 3.64(\mathrm{t}, J=6.4 \mathrm{~Hz}, 2 \mathrm{H}$, $-\mathrm{COCH}_{2}-$ ), 3.60-3.52 (m, 2H, glyco-H-2 + glyco-H-5), 3.48 (dd, J $=9.2,3.3 \mathrm{~Hz}, 1 \mathrm{H}$, glyco-H-3), $2.63\left(\mathrm{t}, J=6.4 \mathrm{~Hz}, 2 \mathrm{H},-\mathrm{CH}_{2} \mathrm{~N}_{3}\right) .{ }^{13} \mathrm{C}$ NMR (126 MHz, MeOH-d $\left.d_{4}\right) \delta 171.27(\mathrm{C}=\mathrm{O}), 139.20(\mathrm{ArC})$, 133.68 (ArC), 130.38 (ArC), 121.39 (ArC), 90.59 (glyco-C-1), 80.61 (glyco-C-5), 76.33 (glyco-C-3), 70.93 (glyco-C-2), 70.43 (glyco-C-4), 62.63 (glyco-C-6), $48.43\left(-\mathrm{COCH}_{2}-\right), 37.08\left(-\mathrm{CH}_{2} \mathrm{~N}_{3}\right)$. HR-MS calcd $\left[\mathrm{C}_{15} \mathrm{H}_{19} \mathrm{~N}_{4} \mathrm{O}_{6} \mathrm{~S}\right]^{-}: 383.1031$, found 383.1036 .

$p$-( $\gamma$-Azidobutyramido)phenyl- $\beta$-D-thiogalactopyranoside (13). The title compound was synthesized from $9(296 \mathrm{mg}, 0.52 \mathrm{mmol}$, 1 eq.) according to general procedure iii and was obtained as a white solid in $81 \%$ yield. ${ }^{1} \mathrm{H}$ NMR $\left(500 \mathrm{MHz}, \mathrm{MeOH}-d_{4}\right) \delta 7.52(\mathrm{~s}, 4 \mathrm{H}, \mathrm{Ar}-$ $\mathrm{H}), 4.50(\mathrm{~d}, J=9.6 \mathrm{~Hz}, 1 \mathrm{H}$, glyco-H-1), $3.88(\mathrm{~d}, J=3.2 \mathrm{~Hz}, 1 \mathrm{H}$, glyco-H-4), $3.76(\mathrm{dd}, J=11.5,6.8 \mathrm{~Hz}, 1 \mathrm{H}$, glyco-H-6), $3.70(\mathrm{dd}, J=$ $11.5,5.3 \mathrm{~Hz}, 1 \mathrm{H}$, glyco-H-6' $), 3.61-3.52(\mathrm{~m}, 2 \mathrm{H}$, glyco-H-2 + glyco$\mathrm{H}-5), 3.48$ (dd, $J=9.2,3.3 \mathrm{~Hz}, 1 \mathrm{H}$, glyco-H-3), $3.39(\mathrm{t}, J=6.7 \mathrm{~Hz}$, $\left.2 \mathrm{H},-\mathrm{COCH}_{2}-\right), 2.47\left(\mathrm{t}, J=7.3 \mathrm{~Hz}, 2 \mathrm{H},-\mathrm{CH}_{2} \mathrm{~N}_{3}\right), 1.94(\mathrm{p}, J=7.0$ $\left.\mathrm{Hz}, 2 \mathrm{H},-\mathrm{CH}_{2}-\right) .{ }^{13} \mathrm{C}$ NMR $\left(126 \mathrm{MHz}, \mathrm{MeOH}-d_{4}\right) \delta 173.37(\mathrm{C}=$ O), 139.37 (ArC), 133.70 ( $\mathrm{ArC}), 130.21$ (ArC), 121.38 ( $\mathrm{ArC}), 90.62$ (glyco-C-1), 80.62 (glyco-C-5), 76.34 (glyco-C-3), 70.94 (glyco-C-2), 70.43 (glyco-C-4), 62.63 (glyco-C-6), $51.92\left(-\mathrm{COCH}_{2}-\right), 34.73$ $\left(-\mathrm{CH}_{2} \mathrm{~N}_{3}\right), 25.94\left(-\mathrm{CH}_{2}-\right)$. HR-MS calcd $\left[\mathrm{C}_{16} \mathrm{H}_{21} \mathrm{~N}_{4} \mathrm{O}_{6} \mathrm{~S}\right]^{-}$: 397.1187, found 397.1189.

$p$-( $\delta$-Azidovalerylamido)phenyl- $\beta$-D-thiogalactopyranoside (14). The title compound was synthesized from $10(327 \mathrm{mg}, 0.56 \mathrm{mmol})$ according to general procedure iii and was obtained as a white solid (235 mg, 84\%). ${ }^{1} \mathrm{H}$ NMR (500 MHz, MeOH- $\left.d_{4}\right) \delta 7.52$ (s, 4H, ArH), $4.49(\mathrm{~d}, J=9.6 \mathrm{~Hz}, 1 \mathrm{H}$, glyco-H-1), $3.88(\mathrm{dd}, J=3.3,0.8 \mathrm{~Hz}, 1 \mathrm{H}$, glyco-H-4), 3.76 (dd, $J=11.5,6.8 \mathrm{~Hz}, 1 \mathrm{H}$, glyco-H-6), 3.70 (dd, $J=$ $11.5,5.3 \mathrm{~Hz}, 1 \mathrm{H}$, glyco-H-6'), 3.62-3.50 (m, 2H, glyco-H-2 + glyco- 
H-5), 3.48 (dd, $J=9.2,3.3 \mathrm{~Hz}, 1 \mathrm{H}$, glyco-H-3), $3.34(\mathrm{t}, J=6.7 \mathrm{~Hz}$, $\left.2 \mathrm{H},-\mathrm{COCH}_{2}-\right), 2.40\left(\mathrm{t}, J=7.4 \mathrm{~Hz}, 2 \mathrm{H},-\mathrm{CH}_{2} \mathrm{~N}_{3}\right), 1.82-1.72(\mathrm{~m}$, $2 \mathrm{H},-\mathrm{CH}_{2} \mathrm{CH}_{2} \mathrm{~N}_{3}$ ), 1.70-1.60 (m, $\left.2 \mathrm{H},-\mathrm{COCH}_{2} \mathrm{CH}_{2}-\right) .{ }^{13} \mathrm{C} \mathrm{NMR}$ $\left(126 \mathrm{MHz}, \mathrm{MeOH}-d_{4}\right) \delta 174.06(\mathrm{C}=\mathrm{O}), 139.39(\mathrm{ArC}), 133.72$ (ArC), 130.18 (ArC), 121.37 (ArC), 90.62 (glyco-C-1), 80.62 (glycoC-5), 76.34 (glyco-C-3), 70.94 (glyco-C-2), 70.43 (glyco-C-4), 62.63 (glyco-C-6), $52.16\left(-\mathrm{CO}^{-} \mathrm{H}_{2}-\right), 37.27 \quad\left(-\underline{\mathrm{C}}_{2} \mathrm{~N}_{3}\right), 29.45$ $\left(-\mathrm{COCH}_{2} \mathrm{CH}_{2}-\right), 23.99\left(-\mathrm{CH}_{2} \mathrm{CH}_{2} \mathrm{~N}_{3}\right)$. HR-MS calcd $\left[\mathrm{C}_{17} \mathrm{H}_{23} \mathrm{~N}_{4} \mathrm{O}_{6} \mathrm{~S}\right]^{-}:$: 411.1344, found 411.1350 .

$\mathrm{N}$-Propargyl-ciprofloxacin (20). The title compound was synthesized in analogy to McPherson et al.: ${ }^{72}$ Ciprofloxacin $(500 \mathrm{mg}, 1.5$ mmol, 1 eq.) was dispersed in $10 \mathrm{~mL}$ of dry DMF together with $\mathrm{Et}_{3} \mathrm{~N}$ $(310 \mu \mathrm{L}, 2.25 \mathrm{mmol}, 1.5$ eq.) and propargyl bromide $(250 \mu \mathrm{L}, 2.25$ mmol, 1.5 eq.). The mixture was stirred at $90{ }^{\circ} \mathrm{C}$ for $24 \mathrm{~h}$, and further equivalents of $\mathrm{Et}_{3} \mathrm{~N}$ (309 $\mu \mathrm{L}, 2 \mathrm{mmol}, 2$ eq.) and propargyl bromide ( $250 \mu \mathrm{L}, 2 \mathrm{mmol}, 2 \mathrm{eq}$.) were added stepwise until the disappearance of the starting material, monitored by TLC (DCM:MeOH, 9:1). The reaction was poured on ice water. After filtration, the precipitate was redissolved and purified by MPLC (DCM:MeOH, 1-10\%) to yield the title product as a beige amorphous solid (353 mg 64\%). ${ }^{1} \mathrm{H}$ NMR $\left(500 \mathrm{MHz}, \mathrm{CHCl}_{3}-d\right) \delta 14.99$ (br s, $\left.1 \mathrm{H}, \mathrm{COOH}\right), 8.77(\mathrm{~s}, 1 \mathrm{H}, \mathrm{ArH}-$ 2), $8.02(\mathrm{~d}, J=13.0 \mathrm{~Hz}, 1 \mathrm{H}, \mathrm{ArH}-5), 7.37(\mathrm{~d}, J=6.7 \mathrm{~Hz}, 1 \mathrm{H}, \mathrm{ArH}-8)$, 3.55 (br s, $1 \mathrm{H}, c \mathrm{Pr}-\underline{\mathrm{H}}$ ), 3.43 (s, $2 \mathrm{H}, \mathrm{HCCCH}_{2}-$ ), 3.41 (br s, $4 \mathrm{H}, 2 \mathrm{x}$ piperazine- $\mathrm{CH}_{2}-$ ), 2.84 (br s, $4 \mathrm{H}, 2 \mathrm{x}$ piperazine- $\mathrm{CH}_{2}{ }^{\prime}-$ ), 2.33 (s, $1 \mathrm{H}$, alkyne-H), 1.39 (d, $\left.J=6.3 \mathrm{~Hz}, 2 \mathrm{H}, c \mathrm{Pr}-\mathrm{CH}_{2}\right), 1.20$ (br s, $2 \mathrm{H}, c \mathrm{Pr}-$ $\left.\mathrm{CH}_{2}{ }^{\prime}\right) \cdot{ }^{13} \mathrm{C}$ NMR $\left(126 \mathrm{MHz}, \mathrm{CHCl}_{3}-d\right) \delta 177.28$ (C4=O), 167.17 $(\underline{\mathrm{COOH}}), 153.82(\mathrm{~d}, J=251.4 \mathrm{~Hz}$, cipro-C-6), 147.61 (cipro-C-2), 145.86 (d, $J=10.1 \mathrm{~Hz}$, cipro-C-7), 139.21 (cipro-C-8a), 120.14 (d, $J$ $=7.6 \mathrm{~Hz}$, cipro-C-4a), 112.67 (d, $J=23.4 \mathrm{~Hz}$ cipro-C-5), 108.35 (cipro-C-3), 105.04 (d, $J=2.4 \mathrm{~Hz}$, cipro-C-8), $74.23\left(\mathrm{HCCCH}_{2}-\right.$ ), $51.52\left(\mathrm{HCCCH}_{2}-\right), 49.67$ (piperazine), 46.95 (piperazine), 35.42 (cPr- $\mathrm{CH}), 8.39\left(c \mathrm{Pr}-\mathrm{CH}_{2}\right),-\mathrm{HCCCH}_{2}-$ (not observed). HR-MS calcd $\left[\mathrm{C}_{20} \mathrm{H}_{21} \mathrm{FN}_{3} \mathrm{O}_{3}\right]^{+}:$370.1561, found 370.1552 .

$\mathrm{N}$-Butynyl-ciprofloxacin (21). Ciprofloxacin $(500 \mathrm{mg}, 1.5 \mathrm{mmol}, 1$ eq.) was dissolved in dry DMF and heated to $70{ }^{\circ} \mathrm{C}$. Over $72 \mathrm{~h}, \mathrm{Et}_{3} \mathrm{~N}$ (1512 $\mu \mathrm{L}, 10.5 \mathrm{mmol}, 7$ eq.) and 4-bromo-1-butyne (982 $\mu \mathrm{L}, 10.5$ mmol, 7 eq.) were added portionwise in 1 eq. steps until the disappearance of the starting material, monitored by TLC (DCM:MeOH, 9:1). The reaction was poured on ice-cold water. After precipitation, the precipitate was purified by MPLC (DCM:MeOH, $1-10 \%$ ) to yield the product as a beige amorphous solid (245 mg, 43\%). ${ }^{1} \mathrm{H}$ NMR (500 MHz, DMSO- $d_{6}$ ) $\delta 15.22$ (br s, $1 \mathrm{H}, \mathrm{COOH}), 8.66$ (s, $1 \mathrm{H}, \mathrm{ArH}-2), 7.89$ (d, $J=13.3 \mathrm{~Hz}, 1 \mathrm{H}, \mathrm{ArH}-5)$, $7.56(\mathrm{~d}, J=7.3 \mathrm{~Hz}, 1 \mathrm{H}, \mathrm{ArH}-8), 3.85-3.77$ (br s, $1 \mathrm{H}, c \mathrm{Pr}-\mathrm{H}), 3.32$ (br s, $4 \mathrm{H}, 2 \mathrm{x}$ piperazine- $\left.\mathrm{CH}_{2}-\right), 2.81\left(\mathrm{~s}, 1 \mathrm{H}, \underline{\mathrm{HCCCH}} \mathrm{CH}_{2}-\right), 2.64$ (br s, $4 \mathrm{H}$, piperazine- $\left.\mathrm{CH}_{2}-\right), 2.56(\mathrm{t}, J=7.2 \mathrm{~Hz}, 2 \mathrm{H}$, $\left.\mathrm{RR}^{\prime} \mathrm{NCH}_{2} \mathrm{CH}_{2} \mathrm{CCH}-\right), 2.38\left(\mathrm{t}, J=6.2 \mathrm{~Hz}, 2 \mathrm{H}, \mathrm{RR}^{\prime} \mathrm{NCH}_{2} \mathrm{CH}_{2} \mathrm{CCH}\right.$ $-), 1.31\left(\mathrm{q}, J=6.0 \mathrm{~Hz}, 2 \mathrm{H}, c \mathrm{Pr}-\mathrm{CH}_{2}-\right), 1.17$ (br s, $2 \mathrm{H}, c \mathrm{Pr}^{\left.-\mathrm{CH}_{2}{ }^{\prime}-\right)}$. ${ }^{13} \mathrm{C}$ NMR (126 MHz, DMSO- $\left.d_{6}\right) \quad \delta \quad 176.40(\mathrm{C} 4=\mathrm{O}), 166.01$ $(\underline{\mathrm{COOH}}), 153.04(\mathrm{~d}, J=249.4 \mathrm{~Hz}$, cipro-C-6), 148.05 (cipro-C-2), 145.22 (cipro-C-7), 139.20 (cipro-C-8a), 118.63 (cipro-C4a), 110.94 (d, $J=23.0 \mathrm{~Hz}$, cipro-C-5), 106.74 (cipro-C-3), 106.44 (cipro-C-8), 83.16 $\left(\mathrm{HCCCH}_{2} \mathrm{CH}_{2}-\right), 71.87\left(\mathrm{HCCCH}_{2} \mathrm{CH}_{2}-\right), 56.26$ $\left(\mathrm{HCCCH}_{2} \mathrm{CH}_{2}-\right), 51.98$ (piperazine), 49.41 (piperazine), 49.38 (piperazine), $35.88(c \mathrm{Pr}-\mathrm{CH}), 16.19\left(\mathrm{HCCCH}_{2} \mathrm{CH}_{2}-\right), 7.59$ (cPr$\left.\mathrm{CH}_{2}\right)$. HR-MS calcd $\left[\mathrm{C}_{21} \mathrm{H}_{23} \mathrm{FN}_{3} \mathrm{O}_{3}\right]^{+}: 384.1718$, found 384.1711 .

Gal-ciprofloxacin Conjugate $22(n=1, m=0)$. The title compound was synthesized from $11(20 \mathrm{mg}, 0.054 \mathrm{mmol}, 1 \mathrm{eq}$.$) and$ 20 (40 mg, $0.108 \mathrm{mmol}, 2 \mathrm{eq}$.) according to general procedure iv and was obtained as a beige amorphous solid $(22 \mathrm{mg}, 55 \%) .{ }^{1} \mathrm{H}$ NMR $\left(500 \mathrm{MHz}, \mathrm{DMSO}-d_{6}\right) \delta 15.22$ (br s, $\left.1 \mathrm{H}, \mathrm{COO} \underline{\mathrm{H}}\right), 10.51(\mathrm{~s}, 1 \mathrm{H}$, $-\mathrm{CONH}-), 8.65$ (s, $1 \mathrm{H}$, cipro-ArH-2), $8.06(\mathrm{~s}, 1 \mathrm{H}$, triazole $\underline{\mathrm{H}}), 7.88$ (d, $J=13.3 \mathrm{~Hz}, 1 \mathrm{H}$, cipro-ArH-5), 7.55 (d, $J=7.4 \mathrm{~Hz}, 1 \mathrm{H}$, cipro-ArH8), $7.52(\mathrm{~d}, J=8.6 \mathrm{~Hz}, 2 \mathrm{H}$, Phenyl-H), $7.43(\mathrm{~d}, J=8.7 \mathrm{~Hz}, 2 \mathrm{H}$, Phenyl-H), $5.32\left(\mathrm{~s}, 2 \mathrm{H},-\mathrm{HNCO}-\mathrm{CH}_{2}\right.$-triazole), $5.11(\mathrm{br} \mathrm{s}, 1 \mathrm{H}, \mathrm{OH})$, 4.85 (br s, $1 \mathrm{H}, \mathrm{OH}), 4.62$ (br s, $1 \mathrm{H}, \mathrm{OH}), 4.48(\mathrm{~d}, J=9.4 \mathrm{~Hz}, 1 \mathrm{H}$, glyco-H-1), 4.44 (br s, $1 \mathrm{H}, \mathrm{OH}), 3.81(\mathrm{~s}, 1 \mathrm{H}, c \mathrm{Pr}-\mathrm{H}), 3.70(\mathrm{~s}, 2 \mathrm{H}$, -triazole- $\mathrm{CH}_{2}-\mathrm{N}$-cipro), 3.69 (br s, $1 \mathrm{H}$, glyco-H-4), 3.53-3.45 (m, $2 \mathrm{H}$, glyco-H-6 + H-6' ), 3.43 (glyco-H-2, extracted from HSQC), 3.38
(glyco-H-5, extracted from HSQC), 3.33 (glyco-H-3, extracted from HSQC), 3.33 (2x piperazine- $\mathrm{CH}_{2}$, extracted from HSQC), 2.65 (s, $4 \mathrm{H}, 2 \mathrm{x}$ piperazine- $\left.\mathrm{CH}_{2}\right), 1.31\left(\mathrm{~d}, J=6.5 \mathrm{~Hz}, 2 \mathrm{H}, c \mathrm{Pr}-\mathrm{CH}_{2}\right), 1.17$ (br s, $\left.2 \mathrm{H}, c \mathrm{Pr}-\mathrm{CH}_{2}{ }^{\prime}\right) \cdot{ }^{13} \mathrm{C}$ NMR $\left(126 \mathrm{MHz}, \mathrm{DMSO}-d_{6}\right) \delta 176.41$ (cipro$\mathrm{C} 4=\mathrm{O}), 166.05(\mathrm{COOH}), 164.34(\mathrm{C}=\mathrm{O}), 153.06(\mathrm{~d}, J=249.3 \mathrm{~Hz}$, cipro-C-6), 148.03 (cipro-C-2), 145.23 (d, $J=10.1 \mathrm{~Hz}$, cipro-C-7), 142.84 (triazole-C), 139.24 (cipro-C-8a), 137.09 (phenyl-C), 131.00 (phenyl-C), 129.46 (phenyl-C), 125.67 (triazole- $\mathrm{CH}$ ), 119.60 (phenyl-C), 118.59 (d, $J=7.5 \mathrm{~Hz}$, cipro-C-4a), 110.98 (d, $J=23.4$ Hz, cipro-C-5), 106.75 (cipro-C-3), 106.43 (d, $J=3.9 \mathrm{~Hz}$, cipro-C-8), 88.17 (glyco-C-1), 79.22 (glyco-C-5), 74.72 (glyco-C-3), 69.26 (glyco-C-2), 68.40 (glyco-C-4), 60.63 (glyco-C-6), 52.29 (-triazole- $\mathrm{CH}_{2}$-N-cipro), 52.17 (- $\mathrm{HNCO}-\mathrm{CH}_{2}$-triazole), 51.83 (piperazine), 49.40 (piperazine), $35.92(c \mathrm{Pr}-\underline{\mathrm{CH}}), 7.61\left(c \mathrm{Pr}-\mathrm{CH}_{2}\right)$. HR-MS calcd $\left[\mathrm{C}_{34} \mathrm{H}_{39} \mathrm{FN}_{7} \mathrm{O}_{9} \mathrm{~S}\right]^{+}:$: 740.2509, found 740.2500.

Gal-ciprofloxacin Conjugate $23(n=1, m=1)$. The title compound was synthesized from $11(20 \mathrm{mg}, 0.054 \mathrm{mmol}, 1 \mathrm{eq}$.$) and$ $21(41 \mathrm{mg}, 0.108 \mathrm{mmol}, 2 \mathrm{eq}$.) according to general procedure iv and was obtained as a beige amorphous solid $(15 \mathrm{mg}, 37 \%) .{ }^{1} \mathrm{H}$ NMR $\left(500 \mathrm{MHz}, \mathrm{DMSO}-d_{6}\right) \delta 15.23$ (br s, $\left.1 \mathrm{H}, \mathrm{COO} \underline{\mathrm{H}}\right), 10.50$ (s, 1, $\mathrm{CONH}), 8.66(\mathrm{~s}, 1 \mathrm{H}$, cipro-ArH-2), $7.94(\mathrm{~s}, 1 \mathrm{H}$, triazole-H), $7.90(\mathrm{~d}$, $J=13.3 \mathrm{~Hz}, 1 \mathrm{H}$, cipro-ArH-5), $7.57(\mathrm{~d}, J=6.6 \mathrm{~Hz}, 1 \mathrm{H}$, cipro-ArH-8), $7.52(\mathrm{~d}, J=8.4 \mathrm{~Hz}, 2 \mathrm{H}$, Phenyl-H), $7.42(\mathrm{~d}, J=8.7 \mathrm{~Hz}, 2 \mathrm{H}$, Phenyl$\left.\mathrm{H}^{\prime}\right), 5.28\left(\mathrm{~s}, 2 \mathrm{H},-\mathrm{HNCOCH}_{2}-\right), 4.48(\mathrm{~d}, J=9.4 \mathrm{~Hz}, 1 \mathrm{H}$, glyco-H1), $3.82(\mathrm{~s}, 1 \mathrm{H}, c \mathrm{Pr}-\mathrm{H}), 3.69(\mathrm{~d}, J=2.8 \mathrm{~Hz}, 1 \mathrm{H}$, glyco-H-4), 3.49 (glyco-H-6 + H-6', extracted from HSQC), 3.43 (glyco-H-2, extracted from HSQC), 3.38 (glyco-H-5, extracted from HSQC), 3.35 (2x piperazine- $\mathrm{CH}_{2}$, extracted from $\left.\mathrm{HSQC}\right), 3.33$ (glyco-H-3, extracted from HSQC), $2.88\left(\mathrm{t}, J=7.5 \mathrm{~Hz}, 2 \mathrm{H},-\right.$ triazole- $\left.\mathrm{CH}_{2} \mathrm{CH}_{2} \mathrm{NRR}^{\prime}\right), 2.68$ (br s, $6 \mathrm{H}, 2 \mathrm{x}$ piperazine- $\mathrm{CH}_{2}+-$ triazole- $\left.\mathrm{CH}_{2} \mathrm{CH}_{2} \mathrm{NRR}^{\prime}\right), 1.31$ (d, $J=$ $6.0 \mathrm{~Hz}, 2 \mathrm{H}, c \mathrm{Pr}-\mathrm{CH}_{2}$ ), 1.18 (br s, $\left.2 \mathrm{H}, c \mathrm{Pr}-\mathrm{CH}_{2}{ }^{\prime}\right) .{ }^{13} \mathrm{C} \mathrm{NMR}(126$ $\left.\mathrm{MHz}, \mathrm{DMSO}-d_{6}\right) \delta 176.42$ (cipro-C4=O), $166.06(\mathrm{COOH}), 164.39$ $(\mathrm{C}=\mathrm{O}), 153.09$ (d, $J=249.8 \mathrm{~Hz}$, cipro-C-6), 148.05 (cipro-C-2), 145.27 (d, J = 9.9 Hz, cipro-C-7), 144.96 (triazole-C), 139.26 (ciproC-8a), 137.11 (phenyl-C), 131.00 (phenyl-C), 129.44 (phenyl-C), 124.00 (triazole- $\underline{\mathrm{CH}}$ ), 119.59 (phenyl-C), $118.58(\mathrm{~d}, J=8.0 \mathrm{~Hz}$, cipro-C-4a), 110.99 (d, $J=23.1 \mathrm{~Hz}$, cipro-C-5), 106.76 (cipro-C-3), 106.38 (d, $J=3.1 \mathrm{~Hz}$, cipro-C-8), 88.17 (glyco-C-1), 79.21 (glyco-C5), 74.72 (glyco-C-3), 69.25 (glyco-C-2), 68.39 (glyco-C-4), 60.63 (glyco-C-6), 57.29 (linker- $\mathrm{CH}_{2}$ ), 52.27 (piperazine), 52.18 (linker$\mathrm{CH}_{2}$ ), 49.43 (piperazine), $35.92(c \mathrm{Pr}-\underline{\mathrm{CH}}), 22.97$ (linker- $\left.\mathrm{CH}_{2}\right), 7.62$ $\left(\mathrm{cPr}-\mathrm{CH}_{2}\right)$. HR-MS calcd $\left[\mathrm{C}_{35} \mathrm{H}_{41} \mathrm{FN}_{7} \mathrm{O}_{9} \mathrm{~S}\right]^{+}:$754.2665, found 754.2658 .

Gal-ciprofloxacin Conjugate $24(n=2, m=0)$. The title compound was synthesized from $12(20 \mathrm{mg}, 0.052 \mathrm{mmol}, 1 \mathrm{eq}$.$) and$ $20(20 \mathrm{mg}, 0.054 \mathrm{mmol}, 1 \mathrm{eq}$. $)$ according to general procedure iv and was obtained as a beige amorphous solid $(26 \mathrm{mg}, 66 \%) .{ }^{1} \mathrm{H}$ NMR $\left(500 \mathrm{MHz}, \mathrm{DMSO}-d_{6}\right) \delta 15.23(\mathrm{br} \mathrm{s}, 1 \mathrm{H}, \mathrm{COOH}), 10.09(\mathrm{~s}, 1 \mathrm{H}$, $\mathrm{CONH}), 8.66(\mathrm{~s}, 1 \mathrm{H}$, cipro-ArH-2), $7.97(\mathrm{~s}, 1 \mathrm{H}$, triazole- $\mathrm{H}), 7.90(\mathrm{~d}$, $J=13.3 \mathrm{~Hz}, 1 \mathrm{H}$, cipro-ArH-5), $7.53(\mathrm{~d}, J=7.4 \mathrm{~Hz}, 1 \mathrm{H}$, cipro-ArH-8), $7.48(\mathrm{~d}, J=8.6 \mathrm{~Hz}, 2 \mathrm{H}$, phenyl-H), $7.37(\mathrm{~d}, J=8.5 \mathrm{~Hz}, 2 \mathrm{H}$, phenyl$\left.\mathrm{H}^{\prime}\right), 5.07(\mathrm{br} \mathrm{s}, 1 \mathrm{H}, \mathrm{OH}), 4.84(\mathrm{br} \mathrm{s}, 1 \mathrm{H}, \mathrm{OH}), 4.65(\mathrm{t}, J=6.6 \mathrm{~Hz}$, $\left.2 \mathrm{H},-\mathrm{NHCOCH}_{2} \mathrm{CH}_{2}-\right), 4.60($ br s, $1 \mathrm{H}, \mathrm{OH}), 4.43(\mathrm{~d}, J=9.2 \mathrm{~Hz}$, $1 \mathrm{H}$, glyco-H-1), 4.43 (br s, $1 \mathrm{H}, \mathrm{OH}), 3.90-3.79$ (br s, $1 \mathrm{H}, c \mathrm{Pr}-\mathrm{H})$, 3.67 (s, $1 \mathrm{H}$, glyco-H-4), $3.64\left(\mathrm{~s}, 2 \mathrm{H},-\right.$ triazole- $\left.\mathrm{CH}_{2}-\mathrm{NRR}^{\prime}\right), 3.47$ (glyco-H-6 + H-6', extracted from HSQC), 3.39 (glyco-H-2, extracted from HSQC), 3.35 (glyco-H-5, extracted from HSQC), 3.30 (glyco$\mathrm{H}-3$, extracted from HSQC), 3.29-3.25 (m, $4 \mathrm{H}, 2 \mathrm{x}$ piperazine- $\left.\mathrm{CH}_{2}\right)$, $2.96\left(\mathrm{t}, J=6.6 \mathrm{~Hz}, 2 \mathrm{H},-\mathrm{NHCOCH}_{2} \mathrm{CH}_{2}-\right), 2.61-2.57(\mathrm{~m}, 4 \mathrm{H}, 2 \mathrm{x}$ piperazine- $\left.\mathrm{CH}_{2}{ }^{\prime}\right), 1.34-1.25\left(\mathrm{~m}, 2 \mathrm{H}, c \mathrm{Pr}-\mathrm{CH}_{2}\right), 1.18-1.15(\mathrm{~m}, 2 \mathrm{H}$, $\left.{ }^{c} \mathrm{Pr}_{-}-\mathrm{CH}_{2}{ }^{\prime}\right) .{ }^{13} \mathrm{C}$ NMR $\left(126 \mathrm{MHz}\right.$, DMSO-d $\left.{ }_{6}\right) \delta 176.43$ (cipro-C4= O), $168.22(\underline{\mathrm{COOH}}), 166.07(\mathrm{C}=\mathrm{O}), 153.07(\mathrm{~d}, J=250.0 \mathrm{~Hz}$, cipro-C-6), 148.07 (cipro-C-2), 145.23 (d, $J=10.1 \mathrm{~Hz}$, cipro-C-7), 142.88 (triazole-C), 139.25 (cipro-C-8a), 137.65 (phenyl-C), 131.13 (phenyl-C), 128.70 (phenyl-C), 124.23 (triazole- $\mathrm{CH}$ ), 119.48 (phenyl-C), 118.61 (d, $J=7.5 \mathrm{~Hz}$, cipro-C-4a), 110.99 (d, $J=22.9$ Hz, cipro-C-5), 106.77 (cipro-C-3), 106.40 (d, $J=2.5 \mathrm{~Hz}$, cipro-C-8), 88.28 (glyco-H-1), 79.19 (glyco-H-5), 74.73 (glyco-H-3), 69.24 (glyco-H-2), 68.36 (glyco-H-4), 60.60 (glyco-H-6), 52.30 (linker$\mathrm{CH}_{2}$ ), 51.80 (piperazine), 49.39 (piperazine), 45.58 (linker- $\left.\mathrm{CH}_{2}\right)$, 
36.56 (linker- $\left.\underline{\mathrm{CH}}_{2}\right), 35.91$ ( $\left.c \mathrm{Pr}-\underline{\mathrm{CH}}\right), 7.61\left(c \mathrm{Pr}-\underline{\mathrm{CH}}_{2}\right)$. HR-MS calcd $\left[\mathrm{C}_{35} \mathrm{H}_{41} \mathrm{FN}_{7} \mathrm{O}_{9} \mathrm{~S}\right]^{+}:$754.2665, found 754.2657.

Gal-ciprofloxacin Conjugate $25(n=2, m=1)$. The title compound was synthesized from $12(30 \mathrm{mg}, 0.078 \mathrm{mmol}, 1$ eq.) and 21 (33 mg, $0.086 \mathrm{mmol}, 1.1$ eq.) according to general procedure iv as and was obtained a beige amorphous solid (35 mg, 58\%). ${ }^{1} \mathrm{H}$ NMR $\left(500 \mathrm{MHz}, \mathrm{DMSO}-d_{6}\right) \delta 15.23$ (br s, $\left.1 \mathrm{H}, \mathrm{COO} \underline{\mathrm{H}}\right), 10.07(\mathrm{~s}, 1 \mathrm{H}$, CONH), 8.66 (s, $1 \mathrm{H}$, cipro-ArH-2), $7.91(\mathrm{~d}, J=13.3 \mathrm{~Hz}, 1 \mathrm{H}$, ciproArH-5), 7.87 (s, $1 \mathrm{H}$, triazole-H), $7.55(\mathrm{~d}, J=7.3 \mathrm{~Hz}, 1 \mathrm{H}$, cipro-ArH8), $7.49(\mathrm{~d}, J=8.7 \mathrm{~Hz}, 2 \mathrm{H}$, phenyl- $\mathrm{H}), 7.38(\mathrm{~d}, J=8.8 \mathrm{~Hz}, 2 \mathrm{H}$, phenyl-H), 5.06 (br s, $1 \mathrm{H}, \mathrm{OH}), 4.83(\mathrm{br} \mathrm{s}, 1 \mathrm{H}, \mathrm{OH}), 4.61(\mathrm{t}, J=6.7$ $\left.\mathrm{Hz}, 2 \mathrm{H},-\mathrm{NHCOCH}_{2} \mathrm{CH}_{2}-+\mathrm{OH}\right), 4.43(\mathrm{~d}, J=9.3 \mathrm{~Hz}, 1 \mathrm{H}$, glyco$\mathrm{H}-1), 4.42(\mathrm{~s}, 1 \mathrm{H}, \mathrm{OH}), 3.83(\mathrm{~s}, 1 \mathrm{H}, \mathrm{OH}), 3.68$ (s, 1H, glyco-H-4), 3.48 (ddd, $J=10.8,6.5,5.5 \mathrm{~Hz}, 2 \mathrm{H}), 3.40(\mathrm{t}, J=6.3 \mathrm{~Hz}, 2 \mathrm{H}$, glyco-H2), $2.95\left(\mathrm{t}, J=6.6 \mathrm{~Hz}, 2 \mathrm{H},-\mathrm{NHCOCH}_{2} \mathrm{CH}_{2}-\right), 2.82(\mathrm{t}, J=7.5 \mathrm{~Hz}$, $2 \mathrm{H}$, -triazole- $\mathrm{CH}_{2} \mathrm{CH}_{2} \mathrm{NRR}^{\prime}$ ), 2.65 (br s, $6 \mathrm{H}, 2 \mathrm{x}$ piperazine- $\mathrm{CH}_{2}+$ -triazole- $\left.\mathrm{CH}_{2} \mathrm{CH}_{2} \mathrm{NRR}^{\prime}\right), 1.31\left(\mathrm{q}, J=7.1 \mathrm{~Hz}, 2 \mathrm{H}, c \mathrm{Pr}-\mathrm{CH}_{2}\right), 1.20-$ $1.16\left(\mathrm{~m}, 2 \mathrm{H}, c \mathrm{Pr}-\mathrm{CH}_{2}\right) .{ }^{13} \mathrm{C}$ NMR $\left(126 \mathrm{MHz}, \mathrm{DMSO}-d_{6}\right) \delta 176.37$ (cipro- $\underline{\mathrm{C}} 4=\mathrm{O}), 168.15(\underline{\mathrm{C}}=\mathrm{O}), 165.98(\underline{\mathrm{COOH}}), 153.02(\mathrm{~d}, J=$ $248.9 \mathrm{~Hz}$, cipro-C-6), 148.02 (cipro-C-2), 145.16 (d, $J=10.5 \mathrm{~Hz}$, cipro-C-7), 144.88 (cipro-C-7), 139.21 (cipro-C-8a), 137.65 (phenylC), 131.05 (phenyl-C), 128.66 (phenyl-C), 122.58 (triazole- $\mathrm{CH}$ ), 119.38 (phenyl-C), 118.55 (d, $J=7.4 \mathrm{~Hz}$, cipro-C-4a), $110.96(\mathrm{~d}, J=$ $23.1 \mathrm{~Hz}$, cipro-C-5), 106.73 (cipro-C-3), 106.32 (d, J = 3.8 Hz, ciproC-8), 88.26 (glyco-C-1), 79.17 (glyco-C-5), 74.69 (glyco-C-3), 69.19 (glyco-C-2), 68.33 (glyco-C-4), 60.57 (glyco-C-6), 57.18 (linker$\mathrm{CH}_{2}$ ), 52.16 (piperazine), 49.35 (piperazine), 45.35 (linker- $\mathrm{CH}_{2}$ ), 36.48 (linker- $\left.\mathrm{CH}_{2}\right), 35.88(\mathrm{cPr}-\mathrm{CH}), 22.87$ (linker- $\left.\mathrm{CH}_{2}\right), 7.58(c \mathrm{Pr}-$ $\left.\mathrm{CH}_{2}\right)$. HR-MS calcd $\left[\mathrm{C}_{36} \mathrm{H}_{43} \mathrm{FN}_{7} \mathrm{O}_{9} \mathrm{~S}\right]^{+}:$768.2822, found 768.2822.

Gal-ciprofloxacin Conjugate $26(n=3, m=0)$. The title compound was synthesized from 13 (30 mg, $0.075 \mathrm{mmol}, 1$ eq.) and $20(31 \mathrm{mg}, 0.083 \mathrm{mmol}, 1.1 \mathrm{eq}$.) according to general procedure iv and was obtained as a beige amorphous solid (30 mg, 52\%). ${ }^{1} \mathrm{H}$ NMR $\left(500 \mathrm{MHz}, \mathrm{DMSO}-d_{6}\right) \delta 15.21$ (br s, $\left.1 \mathrm{H}, \mathrm{COO} \underline{\mathrm{H}}\right), 9.96(\mathrm{~s}, 1 \mathrm{H}$, $\mathrm{CONH}$ ), 8.65 (s, $1 \mathrm{H}$, cipro-ArH-2), $8.06(\mathrm{~s}, 1 \mathrm{H}$, triazole-H), 7.89 (d, $J=13.3 \mathrm{~Hz}, 1 \mathrm{H}$, cipro-ArH-5), $7.54(\mathrm{~d}, J=7.3 \mathrm{~Hz}, 1 \mathrm{H}$, cipro-ArH-8), $7.51(\mathrm{~d}, J=8.6 \mathrm{~Hz}, 2 \mathrm{H}$, phenyl-H), 7.39 (d, $J=8.8 \mathrm{~Hz}, 2 \mathrm{H}$, phenylH), 5.06 (br s, $1 \mathrm{H}, \mathrm{OH}), 4.84$ (br s, $1 \mathrm{H}, \mathrm{OH}), 4.60$ (br s, $1 \mathrm{H}, \mathrm{OH})$, $4.44(\mathrm{~d}, J=9.4 \mathrm{~Hz}, 1 \mathrm{H}$, glyco-H-1), $4.42(\mathrm{OH}$, extracted from COSY $)$ $4.41\left(\mathrm{t}, J=6.9 \mathrm{~Hz}, 1 \mathrm{H},-\mathrm{NHCOCH}_{2} \mathrm{CH}_{2} \mathrm{CH}_{2}-\right), 3.81(\mathrm{~s}, 1 \mathrm{H}, c \mathrm{Pr}-$ $\mathrm{H}), 3.68\left(\mathrm{~s}, 1 \mathrm{H}\right.$, glyco-H-4), $3.66\left(\mathrm{~s}, 2 \mathrm{H},-\right.$ triazol $\left.-\mathrm{CH}_{2}-\mathrm{NRR}^{\prime}\right), 3.56-$ $3.44(\mathrm{~m}, 2 \mathrm{H}$, glyco-H-6 + H-6'), $3.41(\mathrm{t}, J=6.3 \mathrm{~Hz}, 1 \mathrm{H}$, glyco-H-5), 3.37 (glyco-H-2, extracted from HSQC), 3.32 (glyco-H-3, extracted from HSQC), 3.32 (2x piperazine- $\mathrm{CH}_{2}$, extracted from HSQC) 2.64 (br s, 4H, 2x piperazine- $\left.\mathrm{CH}_{2}\right), 2.33(\mathrm{t}, J=7.2 \mathrm{~Hz}, 2 \mathrm{H}$, $\left.-\mathrm{NHCOC \textrm {CH } _ { 2 }} \mathrm{CH}_{2} \mathrm{CH}_{2}-\right), 2.13(\mathrm{tt}, J=7.1 \mathrm{~Hz}, 2 \mathrm{H}$, $\left.-\mathrm{NHCOCH}_{2} \mathrm{CH}_{2} \mathrm{CH}_{2}-\right), 1.33-1.27\left(\mathrm{~m}, 2 \mathrm{H}, c \mathrm{Pr}^{-} \mathrm{CH}_{2}\right), 1.23-1.14$ (br s, $\left.2 \mathrm{H}, c \mathrm{Pr}-\mathrm{CH}_{2}{ }^{\prime}\right) .{ }^{13} \mathrm{C}$ NMR $\left(126 \mathrm{MHz}, \mathrm{DMSO}-d_{6}\right) \delta 176.36$ (cipro-C4=O), $170.11(\mathrm{C}=\mathrm{O}), 165.96(\mathrm{COOH}), 153.01(\mathrm{~d}, J=$ $249.7 \mathrm{~Hz}$, cipro-C-6), 148.00 (cipro-C-2), 145.17 (d, $J=10.1 \mathrm{~Hz}$, cipro-C-7), 143.11 (triazole-C), 139.19 (cipro-C-8a), 137.97 (phenylC), 131.15 (phenyl-C), 128.26 (phenyl-C), 123.81 (triazole- $\mathrm{CH}$ ), 119.34 (phenyl-C), 118.56 (d, $J=7.5 \mathrm{~Hz}$, cipro-C-4a), 110.94 (d, $J=$ $23.1 \mathrm{~Hz}$, cipro-C-5), 106.72 (cipro-C-3), 106.36 (d, $J=3.7 \mathrm{~Hz}$, ciproC-8), 88.34 (glyco-C-1), 79.17 (glyco-C-5), 74.70 (glyco-C-3), 69.20 (glyco-C-2), 68.34 (glyco-C-4), 60.58 (glyco-C-6), 52.41 (linker$\mathrm{CH}_{2}$ ), 51.87 (piperazine), 49.39 (piperazine), 48.84 (linker- $\mathrm{CH}_{2}$ ), $35.85(c \mathrm{Pr}-\mathrm{CH}), 32.91$ (linker- $\left.\mathrm{CH}_{2}\right), 25.51$ (linker- $\left.\mathrm{CH}_{2}\right), 7.57(c \mathrm{Pr}-$ $\mathrm{CH}_{2}$ ). HR-MS calcd $\left[\mathrm{C}_{36} \mathrm{H}_{43} \mathrm{FN}_{7} \mathrm{O}_{9} \mathrm{~S}\right]^{+}:$768.2822, found 768.2815.

Gal-ciprofloxacin Conjugate $27(n=3, m=1)$. The title compound was synthesized from 13 (30 mg, $0.075 \mathrm{mmol}, 1$ eq.) and $21(32 \mathrm{mg}, 0.083 \mathrm{mmol}, 1.1 \mathrm{eq}$.) according to general procedure iv and was obtained as a beige amorphous solid ( $31 \mathrm{mg}, 53 \%) .{ }^{1} \mathrm{H}$ NMR $\left(500 \mathrm{MHz}, \mathrm{DMSO}-d_{6}\right) \delta 15.22$ (br s, $\left.1 \mathrm{H}, \mathrm{COO} \underline{\mathrm{H}}\right), 9.94(\mathrm{~s}, 1 \mathrm{H}$, $\mathrm{CONH}), 8.66(\mathrm{~s}, 1 \mathrm{H}$, cipro-ArH-2), $7.93(\mathrm{~s}, 1 \mathrm{H}$, triazole-H), $7.90(\mathrm{~d}$, $J=13.3 \mathrm{~Hz}, 1 \mathrm{H}$, cipro-ArH-5), $7.56(\mathrm{~d}, J=7.2 \mathrm{~Hz}, 1 \mathrm{H}$, cipro-ArH-8), $7.51(\mathrm{~d}, J=8.6 \mathrm{~Hz}, 2 \mathrm{H}$, phenyl- $\mathrm{H}), 7.38(\mathrm{~d}, J=8.8 \mathrm{~Hz}, 2 \mathrm{H}$, phenylH), 5.06 (br s, $1 \mathrm{H}, \mathrm{OH}), 4.83$ (br s, $1 \mathrm{H}, \mathrm{OH}), 4.59$ (br s, $1 \mathrm{H}, \mathrm{OH})$, $4.44(\mathrm{~d}, J=9.4 \mathrm{~Hz}, 1 \mathrm{H}$, glyco-H-1), $4.42($ br s, $1 \mathrm{H}, \mathrm{OH}), 4.38(\mathrm{t}, J=$
$6.8 \mathrm{~Hz}, 2 \mathrm{H},-\mathrm{NHCOC \textrm {CH } _ { 2 }} \mathrm{CH}_{2} \mathrm{CH}_{2}-$ ), 3.82 (br s, $\left.1 \mathrm{H}, \mathrm{cPr}-\mathrm{H}\right), 3.68$ (s, $1 \mathrm{H}$, glyco-H-4), 3.53-3.44 (m, 2H, glyco-H-6 + H-6'), $3.41(\mathrm{t}, J=6.3$ $\mathrm{Hz}, 1 \mathrm{H}$, glyco-H-5), 3.37 (glyco-H-2 ,extracted from HSQC), 3.34 (2x piperazine- $\mathrm{CH}_{2}$, extracted from HSQC), 3.32 (glyco-H-3) 2.84 (t, $J=7.6 \mathrm{~Hz}, 2 \mathrm{H},-$ triazole $\left.-\mathrm{CH}_{2} \mathrm{CH}_{2} \mathrm{NRR}^{\prime}\right), 2.67$ (br s, $6 \mathrm{H}, 2 \mathrm{x}$ piperazine- $\mathrm{CH}_{2}+$-triazole- $\left.\mathrm{CH}_{2} \mathrm{CH}_{2} \mathrm{NRR}^{\prime}\right), 2.31(\mathrm{t}, J=7.3 \mathrm{~Hz}, 2 \mathrm{H}$, $\left.-\mathrm{NHCOCH}_{2} \mathrm{CH}_{2} \mathrm{CH}_{2}-\right), 2.11(\mathrm{tt}, J=8.1,7.5 \mathrm{~Hz}, 2 \mathrm{H}$, $\left.-\mathrm{NHCOCH}_{2} \mathrm{CH}_{2} \mathrm{CH}_{2}-\right)$, 1.36-1.28 (m, 2H, $\left.c \mathrm{Pr}^{-} \mathrm{CH}_{2}\right), 1.21-1.13$ $\left(\mathrm{m}, 2 \mathrm{H}, c \mathrm{Pr}-\mathrm{CH}_{2}\right) \cdot{ }^{13} \mathrm{C}$ NMR $\left(126 \mathrm{MHz}\right.$, DMSO- $\left.d_{6}\right) \delta 176.37$ (cipro$\mathrm{C} 4=\mathrm{O}), 170.11(\mathrm{CO}), 165.97(\underline{\mathrm{COOH}}), 153.03(\mathrm{~d}, J=249.5 \mathrm{~Hz}$, cipro-C-6), 148.01 (cipro-C-2), 145.19 (d, $J=9.9 \mathrm{~Hz}$, cipro-C-7), 145.05 (triazole-C), 139.20 (cipro-C-8a), 137.95 (phenyl-C), 131.12 (phenyl-C), 128.27 (phenyl-C), 122.21 (triazole- $\mathrm{CH}$ ), 119.33 (phenyl-C), 118.56 (d, $J=8.0 \mathrm{~Hz}$, cipro-C-4a), 110.94 (d, $J=23.1$ Hz, cipro-C-5), 106.73 (cipro-C-3), 106.35 (d, $J=3.2 \mathrm{~Hz}$, cipro-C-8), 88.33 (glyco-C-1), 79.17 (glyco-C-5), 74.70 (glyco-C-3), 69.20 (glyco-C-2), 68.34 (glyco-C-4), 60.58 (glyco-C-6), 57.21 (linker$\mathrm{CH}_{2}$ ), 52.19 (piperazine), 49.40 (piperazine), 48.74 (linker- $\mathrm{CH}_{2}$ ), 35.87 (cPr- $\mathrm{CH}), 32.90$ (linker- $\left.\mathrm{CH}_{2}\right), 25.53$ (linker- $\left.\mathrm{CH}_{2}\right), 22.98$ $\left(\right.$ linker- $\left.\mathrm{CH}_{2}\right), 7.58 \quad\left(c \mathrm{Pr}-\mathrm{CH}_{2}\right)$. HR-MS calcd $\left[\mathrm{C}_{37} \mathrm{H}_{45} \mathrm{FN}_{7} \mathrm{O}_{9} \mathrm{~S}\right]^{+}$: 782.2987, found 782.2965 .

Gal-ciprofloxacin Conjugate $28(n=4, m=0)$. The title compound was synthesized from $14(30 \mathrm{mg}, 0.073 \mathrm{mmol}, 1 \mathrm{eq}$.$) and$ $20(30 \mathrm{mg}, 0.08 \mathrm{mmol}, 1.1 \mathrm{eq}$.) according to general procedure iv and was obtained as a beige amorphous solid $(25 \mathrm{mg}, 43 \%) .{ }^{1} \mathrm{H}$ NMR $\left(500 \mathrm{MHz}, \mathrm{DMSO}-d_{6}\right) \delta 15.21$ (br s, $\left.1 \mathrm{H}, \mathrm{COO} \underline{\mathrm{H}}\right), 9.93(\mathrm{~s}, 1 \mathrm{H}$, CONH), 8.65 (s, 1H, cipro-ArH-2), $8.05(\mathrm{~s}, 1 \mathrm{H}$, triazole- $\mathrm{H}), 7.89$ (d, $J=13.3 \mathrm{~Hz}, 1 \mathrm{H}$, cipro-ArH-5), 7.54 (d, $J=8.1 \mathrm{~Hz}, 1 \mathrm{H}$, cipro-ArH-5), $7.51(\mathrm{~d}, J=8.5 \mathrm{~Hz}, 2 \mathrm{H}$, phenyl- $\mathrm{H}), 7.38(\mathrm{~d}, J=8.4 \mathrm{~Hz}, 2 \mathrm{H}$, phenylH), $5.06($ br s, $1 \mathrm{H}, \mathrm{OH}), 4.84($ br s, $1 \mathrm{H}, \mathrm{OH}), 4.59($ br s, $1 \mathrm{H}, \mathrm{OH})$, $4.43(\mathrm{~d}, J=9.4 \mathrm{~Hz}, 2$, glyco-H-1 $+\mathrm{OH}), 4.37(\mathrm{t}, J=6.9 \mathrm{~Hz}, 2 \mathrm{H}$, $-\mathrm{NHCOCH}_{2} \mathrm{CH}_{2} \mathrm{CH}_{2} \mathrm{CH}_{2}-$ ), 3.81 (s, $\left.1 \mathrm{H}, c \mathrm{Pr}-\mathrm{H}\right), 3.68$ (br s, $1 \mathrm{H}$, glyco-H-4), 3.65 (s, $2 \mathrm{H},-$ triazole- $\left.\mathrm{CH}_{2} \mathrm{CH}_{2} \mathrm{NRR}^{\prime}\right), 3.56-3.44$ (m, $2 \mathrm{H}$, glyco-H-6 + H-6'), $3.41(\mathrm{~d}, J=6.0 \mathrm{~Hz}, 19 \mathrm{H}$ ), 3.40 (glyco-H-5, extracted from HSQC), 3.37 (glyco-H-2, extracted from HSQC), 3.32 (2x piperazine- $\mathrm{CH}_{2}$, extracted from $\mathrm{HSQC}$ ), 2.63 (br s, $4 \mathrm{H}, 2 \mathrm{x}$ piperazine- $\left.\mathrm{CH}_{2}{ }^{\prime}\right), 2.34(\mathrm{t}, J=7.4 \mathrm{~Hz}, 2 \mathrm{H}$, $\left.-\mathrm{NHCOCH}_{2} \mathrm{CH}_{2} \mathrm{CH}_{2} \underline{\mathrm{CH}}_{2}-\right), 1.86(\mathrm{tt}, J=7.1 \mathrm{~Hz}, 2 \mathrm{H}$, $\left.-\mathrm{NHCOCH}_{2} \mathrm{CH}_{2} \mathrm{CH}_{2} \mathrm{CH}_{2}-\right), 1.55(\mathrm{tt}, J=7.5 \mathrm{~Hz}, 2 \mathrm{H}$, $\left.-\mathrm{NHCOCH}_{2} \mathrm{CH}_{2} \mathrm{CH}_{2} \mathrm{CH}_{2}-\right), 1.39-1.26\left(\mathrm{~m}, 2 \mathrm{H}, c \mathrm{Pr}-\mathrm{CH}_{2}\right), 1.22-$ $1.12\left(\mathrm{~m}, 2 \mathrm{H}, c \mathrm{Pr}-\mathrm{CH}_{2}\right) \cdot{ }^{13} \mathrm{C}$ NMR $\left(126 \mathrm{MHz}, \mathrm{DMSO}-d_{6}\right) \delta 176.36$ (cipro-C4=O), $170.82(\mathrm{C}=\mathrm{O}), 165.96(\underline{\mathrm{COOH}}), 153.01(\mathrm{~d}, J=$ $249.9 \mathrm{~Hz}$, cipro-C-6), 148.01 (cipro-C-2), 145.17 (d, $J=9.9 \mathrm{~Hz}$, cipro-C-7), 143.02 (triazole-C), 139.19 (cipro-C-8a), 138.03 (phenylC), 131.15 (phenyl-C), 128.20 (phenyl-C), 123.77 (triazole- $\underline{\mathrm{CH}}$ ), 119.31 (phenyl-C), 118.56 (d, $J=7.8 \mathrm{~Hz}$, cipro-C-4a), 110.94 (d, $J=$ $23.2 \mathrm{~Hz}$, cipro-C-5), 106.72 (cipro-C-3), 106.37 (d, $J=3.0 \mathrm{~Hz}$, ciproC-8), 88.35 (glyco-C-1), 79.17 (glyco-C-5), 74.69 (glyco-C-3), 69.20 (glyco-C-2), 68.33 (glyco-C-4), 60.57 (glyco-C-6), 52.40 (linker$\mathrm{CH}_{2}$ ), 51.86 (piperazine), 49.39 (piperazine), 49.03 (linker- $\mathrm{CH}_{2}$ ), 35.85 (cPr- $\mathrm{CH}), 35.59$ (linker- $\left.\mathrm{CH}_{2}\right), 29.34$ (linker- $\left.\mathrm{CH}_{2}\right), 22.01$ (linker- $\left.\mathrm{CH}_{2}\right), 7.57 \quad\left(c \mathrm{Pr}-\underline{\mathrm{C}} \mathrm{H}_{2}\right)$. HR-MS calcd $\left[\mathrm{C}_{37} \mathrm{H}_{45} \mathrm{FN}_{7} \mathrm{O}_{9} \mathrm{~S}\right]^{+}$: 782.2987, found 782.2972 .

Gal-ciprofloxacin Conjugate $29(n=4, m=1)$. The title compound was synthesized from 14 (30 mg, $0.073 \mathrm{mmol}, 1 \mathrm{eq}$.) and 21 (56 mg, $0.146 \mathrm{mmol}, 2 \mathrm{eq}$.) according to general procedure iv and was obtained as a beige amorphous solid (28 mg, 48\%). ${ }^{1} \mathrm{H}$ NMR $\left(500 \mathrm{MHz}, \mathrm{DMSO}-d_{6}\right) \delta 15.23(\mathrm{br} \mathrm{s}, 1 \mathrm{H}, \mathrm{COOH}), 9.93(\mathrm{~s}, 1 \mathrm{H}$, $\mathrm{CONH}), 8.66(\mathrm{~s}, 1 \mathrm{H}$, cipro-ArH-2), 7.93-7.86 (m, $2 \mathrm{H}$, triazole- $\mathrm{H}+$ cipro-ArH-5), 7.55 (d, $J=7.2 \mathrm{~Hz}, 1 \mathrm{H}$, cipro-ArH-8), 7.50 (d, $J=8.6$ $\mathrm{Hz}, 2 \mathrm{H}$, phenyl-H), 7.37 (d, $J=8.6 \mathrm{~Hz}, 2 \mathrm{H}$, phenyl- $\mathrm{H}^{\prime}$ ), 5.07 (br s, $1 \mathrm{H}, \mathrm{OH}), 4.84(\mathrm{br} \mathrm{s}, 1 \mathrm{H}, \mathrm{OH}), 4.62(\mathrm{br} \mathrm{s}, 1 \mathrm{H}, \mathrm{OH}), 4.43(\mathrm{~d}, J=9.2$ $\mathrm{Hz}, 2 \mathrm{H}$, glyco-H-1 $+\mathrm{OH}), 4.34(\mathrm{t}, J=6.9 \mathrm{~Hz}, 2 \mathrm{H}$, $-\mathrm{NHCOCH}_{2} \mathrm{CH}_{2} \mathrm{CH}_{2} \mathrm{CH}_{2}-$ ), 3.81 (br s, $\left.1 \mathrm{H},\right), 3.68(\mathrm{~s}, 1 \mathrm{H}$, glyco$\mathrm{H}-4), 3.49$ (glyco-H-6 + H-6', extracted from HSQC), 3.41 (glyco-H5 , extracted from HSQC), 3.37 (glyco-H-2, extracted from HSQC), 3.34 (2x piperazine- $\mathrm{CH}_{2}$, extracted from HSQC), 3.32 (glyco-H-3, extracted from HSQC), $2.84(\mathrm{t}, J=7.5 \mathrm{~Hz}, 2 \mathrm{H},-$-triazole$\mathrm{CH}_{2} \mathrm{CH}_{2} \mathrm{NRR}^{\prime}$ ), 2.67 (br s, $6 \mathrm{H}, 2 \mathrm{x}$ piperazine- $\mathrm{CH}_{2}+-$ triazole- 
$\left.\mathrm{CH}_{2} \underline{\mathrm{CH}}_{2} \mathrm{NRR}^{\prime}\right), 2.33(\mathrm{t}, \quad J=7.3 \mathrm{~Hz}, 2 \mathrm{H}$, $\left.-\mathrm{NHCOCH}_{2} \mathrm{CH}_{2} \mathrm{CH}_{2} \mathrm{CH}_{2}-\right), 1.83(\mathrm{tt}, J=6.9 \mathrm{~Hz}, 2 \mathrm{H}$, $\left.-\mathrm{NHCOCH}_{2} \mathrm{CH}_{2} \mathrm{CH}_{2} \mathrm{CH}_{2}-\right), 1.54(\mathrm{tt}, J=7.4 \mathrm{~Hz}, 2 \mathrm{H}$, $-\mathrm{NHCOCH}_{2} \mathrm{CH}_{2} \mathrm{CH}_{2} \mathrm{CH}_{2}-$ ), 1.36-1.24 (m, $\left.2 \mathrm{H}, c \mathrm{Pr}-\mathrm{CH}_{2}\right), 1.25-$

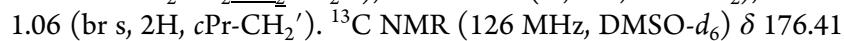
(cipro-C4=O), $170.89(\mathrm{C}=\mathrm{O}), 166.04(\underline{\mathrm{COOH}}), 153.07(\mathrm{~d}, J=$ $249.6 \mathrm{~Hz}$, cipro-C-6), 148.04 (cipro-C-2), 145.23 (d, $J=9.9 \mathrm{~Hz}$, cipro-C-7), 144.99 (triazole-C), 139.24 (cipro-C-8a), 138.05 (phenylC), 131.19 (phenyl-C), 128.23 (phenyl-C), 122.23 (triazole- $\mathrm{CH}$ ), 119.35 (phenyl-C), 118.58 (d, $J=7.5 \mathrm{~Hz}$, cipro-C-4a), 110.98 (d, $J=$ $23.2 \mathrm{~Hz}$, cipro-C-5), 106.75 (cipro-C-3), 106.36 (d, $J=3.0 \mathrm{~Hz}$, ciproC-8), 88.37 (glyco-C-1), 79.19 (glyco-C-5), 74.72 (glyco-C-3), 69.24 (glyco-C-2), 68.38 (glyco-C-4), 60.62 (glyco-C-6), 57.25 (linker$\mathrm{CH}_{2}$ ), 52.21 (piperazine), 49.41 (piperazine), 49.00 (linker- $\mathrm{CH}_{2}$ ), 35.90 (cPr- $\mathrm{CH}), 35.66$ (linker- $\left.\mathrm{CH}_{2}\right), 29.40$ (linker- $\left.\mathrm{CH}_{2}\right), 22.99$ (linker- $\left.\mathrm{CH}_{2}\right), 22.07 \quad\left(\right.$ linker- $\left.\mathrm{CH}_{2}\right), 7.61 \quad\left(c \mathrm{Pr}-\mathrm{CH}_{2}\right)$. HR-MS calcd $\left[\mathrm{C}_{37} \mathrm{H}_{45} \mathrm{FN}_{7} \mathrm{O}_{9} \mathrm{~S}\right]^{+}$: 796.3135, found 796.3128 .

5-(2'-Bromoethyl)thiophene-2-sulfonyl Chloride (16). 16 was synthesized in two chemical steps: thiopheneethanol $15(1.0 \mathrm{~mL}, 9.0$ mmol, 1 eq.) was dissolved in $40 \mathrm{~mL}$ of dry $\mathrm{CH}_{2} \mathrm{Cl}_{2}$. The solution was cooled $\left(0{ }^{\circ} \mathrm{C}\right)$, and a solution of $\mathrm{PBr}_{3}(846 \mu \mathrm{L}, 9.0 \mathrm{mmol}, 1$ eq. $)$ in dry $\mathrm{CH}_{2} \mathrm{Cl}_{2}$ was added dropwise under vigorous stirring; the reaction was stirred for $1 \mathrm{~h}$ until full transformation, monitored by TLC (PE:EtOAc, 95:5). The reaction was quenched with ice water. The organic phase was washed with water $(2 \mathrm{x})$, aq. half satd. $\mathrm{Na}_{2} \mathrm{CO}_{3}$ $(2 \mathrm{x})$, and brine and dried over anhydrous $\mathrm{Na}_{2} \mathrm{SO}_{4}$. The organic phase was reduced in vacuo and filtered over silica. After evaporation of the solvent in vacuo crude 2-(2'-bromoethyl)thiophene was obtained as a yellow oil (490 mg, 28\%). ${ }^{1} \mathrm{H}$ NMR $\left(500 \mathrm{MHz}, \mathrm{CHCl}_{3}-d\right) \delta 7.20(\mathrm{dd}$, $J=5.1,1.2 \mathrm{~Hz}, 1 \mathrm{H}, \mathrm{ArH}-5), 6.97$ (dd, $J=5.1,3.5 \mathrm{~Hz}, 1 \mathrm{H}, \mathrm{ArH}-4)$, $6.90(\mathrm{dd}, J=3.4,1.0 \mathrm{~Hz}, 1 \mathrm{H}, \mathrm{ArH}-3), 3.58(\mathrm{t}, J=7.4 \mathrm{~Hz}, 2 \mathrm{H}$, $\left.-\mathrm{CH}_{2} \mathrm{CH}_{2} \mathrm{Br}\right), 3.38\left(\mathrm{t}, J=7.5 \mathrm{~Hz}, 2 \mathrm{H},-\underline{\mathrm{CH}}_{2} \mathrm{CH}_{2} \mathrm{Br}\right)$. 2- $\left(2^{\prime}-\right.$ Bromoethyl)thiophene ( $255 \mathrm{mg}, 1.33 \mathrm{mmol}, 1$ eq.) was dissolved in $10 \mathrm{~mL}$ of dry $\mathrm{CH}_{2} \mathrm{Cl}_{2}$, and the mixture was cooled $\left(0{ }^{\circ} \mathrm{C}\right) . \mathrm{HSO}_{3} \mathrm{Cl}$ (266 $\mu \mathrm{L}, 4 \mathrm{mmol}$, 3 eq.) was dissolved in $5 \mathrm{~mL}$ of dry $\mathrm{CH}_{2} \mathrm{Cl}_{2}$ and added dropwise to the starting material under vigorous stirring. The reaction was stirred $1 \mathrm{~h}$ until full transformation, monitored by TLC (PE:EtOAc, 95:5). The reaction was quenched with ice water. The aqueous phase was extracted with $\mathrm{CH}_{2} \mathrm{Cl}_{2}(3 \mathrm{x})$. The combined organic phases were washed with half satd. brine $(\mathrm{x})$ and brine $(1 \mathrm{x})$ and dried over anhydrous $\mathrm{Na}_{2} \mathrm{SO}_{4}$. The solvent was evaporated in vacuo to obtain the crude product as a dark yellow oil $(261 \mathrm{mg})$.

$\beta$-L-Fucopyranosyl-1-methylamine (17). $\beta$-L-Fucopyranosyl-1-nitromethane was synthesized according to Phiasivongsa et al. ${ }^{73}$ with subsequent reduction to the amine as previously described in Sommer et al. ${ }^{42}$ NMR in agreement with literature data. ${ }^{42}$

$N$ - $\beta$-L-Fucopyranosylmethyl-2-(5-(2'-azidoethyl)thiophene)sulfonamide (19). $\beta$-L-Fucopyranosyl-1-methylamine $(17,128 \mathrm{mg}$, $0.60 \mathrm{mmol}, 1$ eq.) and $\mathrm{K}_{2} \mathrm{CO}_{3}(166 \mathrm{mg}, 1.2 \mathrm{mmol}, 2$ eq. $)$ were dispersed in $6 \mathrm{~mL}$ of dry DMF and cooled to $0{ }^{\circ} \mathrm{C}$. Crude 2chlorosulfonyl-5-(2'-bromoethyl)thiophene $(261 \mathrm{mg}, 0.90 \mathrm{mmol})$ was dissolved in $6 \mathrm{~mL}$ of dry DMF and added dropwise to the starting material under vigorous stirring. The reaction was stirred for $3 \mathrm{~h}$ until full conversion, as monitored by TLC (MeOH:EtOAc:aq. $\mathrm{NH}_{4} \mathrm{OH}$ $25 \%, 4: 4: 2)$. After quenching with water, the aqueous phase was extracted with EtOAc (4x). The combined organic layers were washed with half satd. brine $(3 \mathrm{x})$ and brine $(1 \mathrm{x})$ and dried over anhydrous $\mathrm{Na}_{2} \mathrm{SO}_{4}$. After filtration, the solvent was evaporated in vacuo and the crude material $\left(191 \mathrm{mg}\right.$ ) was dissolved in $10 \mathrm{~mL}$ of dry DMF. $\mathrm{NaN}_{3}$ (143 mg, $2.2 \mathrm{mmol}$ ) was added, and the mixture was stirred for $3 \mathrm{~h}$. After full transformation (monitored by HPLC-MS), the reaction was diluted with water and extracted with EtOAc $(3 \mathrm{x})$. The combined organic layers were washed with half satd. brine $(3 \mathrm{x})$ and satd. brine (1x) and dried over anhydrous $\mathrm{Na}_{2} \mathrm{SO}_{4}$. After filtration, the solvent was evaporated in vacuo, and the product was purified by MPLC (DCM:MeOH, 1-11\%) to yield the target compound as a white amorphous solid $(141 \mathrm{mg}, 60 \%$ after three chemical steps, $8 \%$ impurity of the corresponding alkyl chloride, determined by ${ }^{1} \mathrm{H}$ NMR). ${ }^{1} \mathrm{H}$ NMR $\left(500 \mathrm{MHz}, \mathrm{MeOH}-d_{4}\right) \delta 7.46(\mathrm{~d}, J=3.8 \mathrm{~Hz}, 1 \mathrm{H}$, Ar- $\mathrm{H}), 6.97(\mathrm{~d}, J=3.7 \mathrm{~Hz}, 1 \mathrm{H}, \operatorname{Ar}-\mathrm{H}), 3.65-3.57(\mathrm{~m}, 3 \mathrm{H}$,
$\left.-\underline{\mathrm{CH}}_{2} \mathrm{CH}_{2} \mathrm{~N}_{3}+\mathrm{H}-4\right), 3.50(\mathrm{q}, J=7.0 \mathrm{~Hz}, 1 \mathrm{H}, \mathrm{H}-5), 3.45-3.34(\mathrm{~m}$, $\left.3 \mathrm{H},-\mathrm{CH}_{2} \mathrm{~N}-+\mathrm{H}-2\right), 3.17(\mathrm{td}, J=9.1,8.6,2.4 \mathrm{~Hz}, 1 \mathrm{H}, \mathrm{H}-1), 3.12(\mathrm{t}$, $\left.J=6.6 \mathrm{~Hz}, 2 \mathrm{H},-\mathrm{CH}_{2} \mathrm{CH}_{2} \mathrm{~N}_{3}\right), 3.06(\mathrm{dd}, J=12.9,7.2 \mathrm{~Hz}, 1 \mathrm{H}$, $-\mathrm{CH}_{2}{ }^{\prime} \mathrm{N}-$ ), 1.20 (d, $\left.J=6.5 \mathrm{~Hz}, 3 \mathrm{H}, \mathrm{H}-6\right) .{ }^{13} \mathrm{C}$ NMR (126 MHz, $\mathrm{MeOH}-d_{4}$ ) $\delta 149.48$ (Ar-C), 141.03 (Ar-C), 132.98 (Ar-C), 127.32 (Ar-C), 79.55 (glyco-C-2), 76.37 (glyco-C-3), 75.57 (glyco-C-5), 73.61 (glyco-C-4), 69.74 (glyco-C-1), 53.08 (glyco-C-2), 45.75 (linker- $\mathrm{CH}_{2}$ ), 30.71 (linker- $\mathrm{CH}_{2}$ ), 17.07 (glyco-C-6). HR-MS calcd $\left[\mathrm{C}_{13} \mathrm{H}_{19} \mathrm{~N}_{4} \mathrm{O}_{6} \mathrm{~S}_{2}\right]^{-}$: 391.0751, found 391.0759.

Hybrid-Ciprofloxacin Conjugate $30(m=0)$. The title compound was synthesized from 19 (35 mg, $0.09 \mathrm{mmol}, 1$ eq.) and $20(35 \mathrm{mg}$, $0.095 \mathrm{mmol}, 1.1$ eq.) according to general procedure iv and was obtained as a beige amorphous solid (30 mg, 44\%). ${ }^{1} \mathrm{H}$ NMR (500 $\left.\mathrm{MHz}, \mathrm{DMSO}-d_{6}\right) \delta 15.23$ (br s, $\left.1 \mathrm{H},-\mathrm{COOH}\right), 8.66$ (s, $1 \mathrm{H}$, cipro-H2), $7.98(\mathrm{~s}, 1 \mathrm{H}$, triazole- $\mathrm{H}), 7.90(\mathrm{~d}, J=13.3 \mathrm{~Hz}, 1 \mathrm{H}$, cipro- $\mathrm{H}-5), 7.66$ $\left(\mathrm{t}, J=5.9 \mathrm{~Hz}, 1 \mathrm{H},-\mathrm{NHSO}_{2}-\right), 7.55(\mathrm{~d}, J=7.4 \mathrm{~Hz}, 1 \mathrm{H}$, cipro-H-8), $7.37(\mathrm{~d}, J=3.7 \mathrm{~Hz}, 1 \mathrm{H}$, thienyl-H), 6.89 (d, $J=3.8 \mathrm{~Hz}, 1 \mathrm{H}$, thienyl$\mathrm{H}), 4.80(\mathrm{br} \mathrm{s}, 1 \mathrm{H}, \mathrm{OH}), 4.65\left(\mathrm{t}, J=6.7 \mathrm{~Hz}, 1 \mathrm{H}\right.$, thiophene- $\mathrm{CH}_{2} \mathrm{CH}_{2}-$ triazole), 4.59 (br s, $1 \mathrm{H}, \mathrm{OH}), 4.28(\mathrm{~d}, J=5.5 \mathrm{~Hz}, 1 \mathrm{H}, \mathrm{OH}), 3.86-$ $3.77(\mathrm{~m}, 1 \mathrm{H}, c \mathrm{Pr}-\mathrm{H}), 3.63\left(\mathrm{~s}, 2 \mathrm{H}\right.$, triazole- $\left.\mathrm{CH}_{2}-\mathrm{NRR}^{\prime}\right), 3.47(\mathrm{t}, J=6.7$ $\mathrm{Hz}, 2 \mathrm{H}$, thiophene- $\mathrm{CH}_{2} \mathrm{CH}_{2}$-triazole), 3.39 (s, $1 \mathrm{H}$, glyco-H-4), 3.37, 3.25-3.18 (m, $2 \mathrm{H},-\mathrm{CH}_{2} \mathrm{NHSO}_{2}-+$ glyco-H-3), $3.14(\mathrm{t}, J=9.3 \mathrm{~Hz}$, $1 \mathrm{H}$, glyco-H-2), 3.01 (td, $J=8.8,2.3 \mathrm{~Hz}, 1 \mathrm{H}$, glyco-H-1), 2.73 (ddd, $J$ $\left.=13.4,8.4,5.6 \mathrm{~Hz}, 1 \mathrm{H},-\mathrm{CH}_{2} \mathrm{NHSO}_{2}-\right), 2.59(2.63-2.56 \mathrm{~m}, 4 \mathrm{H}, 2 \mathrm{x}$ piperazine- $\left.\mathrm{CH}_{2}\right), 1.39-1.30\left(\mathrm{~m}, 2 \mathrm{H}, c \mathrm{Pr}-\mathrm{CH}_{2}\right), 1.20-1.14(\mathrm{~m}, 4 \mathrm{H}$, cPr- $\left.\mathrm{CH}_{2}\right), 1.07$ (d, $J=6.4 \mathrm{~Hz}, 3 \mathrm{H}$, glyco-H-6). ${ }^{13} \mathrm{C}$ NMR $(126 \mathrm{MHz}$, DMSO- $\left.d_{6}\right) \delta 176.38($ cipro-C4=O), $165.98(\mathrm{COOH}), 153.02(\mathrm{~d}, J=$ $249.2 \mathrm{~Hz}$, cipro-C-6), 147.98 (cipro-C-2), 146.07 (Ar-C), 145.23 (d, J $=10.1 \mathrm{~Hz}$, cipro-C-7), 143.18 (triazole-C), 139.65 (Ar-C), 139.23 (cipro-C-8a), 131.14 (Ar-C), 126.59 (Ar-C), 124.22 (triazole- $\underline{\mathrm{CH}}$ ), 118.56 (d, $J=7.4 \mathrm{~Hz}$, cipro-C-4a), 110.95 (d, $J=22.9 \mathrm{~Hz}$, cipro-C-5), 106.72 (cipro-C-3), 106.34 (d, $J=2.6 \mathrm{~Hz}$, cipro-C-8), 78.24 (glycoC-2), 74.64 (glyco-C-3), 73.64 (glyco-C-5), 71.56 (glyco-C-4), 68.30 (glyco-C-1), 52.41 (linker- $\mathrm{CH}_{2}$ ), 51.88 (piperazine), 50.01 (linker$\left.\mathrm{CH}_{2}\right), 49.40$ (piperazine), $44.74\left(\right.$ glyco- $\left.\mathrm{CH}_{2}\right), 35.90(\mathrm{cPr}-\underline{\mathrm{CH}}), 29.97$ (linker- $\left.\mathrm{CH}_{2}\right), 16.93$ (glyco-C-6), $7.57\left(c \mathrm{Pr}-\mathrm{C}_{2}\right)$. HR-MS calcd $\left[\mathrm{C}_{33} \mathrm{H}_{41} \mathrm{FN}_{7} \mathrm{O}_{9} \mathrm{~S}_{2}\right]^{+}:$762.2386, found 762.2382 .

Hybrid-Ciprofloxacin Conjugate $31(m=1)$. The title compound was synthesized from 19 (56 mg, $0.14 \mathrm{mmol}, 1$ eq.) and 21 (59 mg, $0.15 \mathrm{mmol}, 1.1 \mathrm{eq}$.) according to general procedure iv and was obtained as a beige amorphous solid $(57 \mathrm{mg}, 52 \%) .{ }^{1} \mathrm{H}$ NMR (500 $\left.\mathrm{MHz}, \mathrm{DMSO}-d_{6}\right) \delta 15.23(\mathrm{~s}, 1 \mathrm{H}, \mathrm{COO} \underline{\mathrm{H}}), 8.67$ (s, $1 \mathrm{H}$, cipro-ArH-2), 7.93-7.89 (m, $2 \mathrm{H}$, triazole- $\mathrm{H}+$ cipro-ArH-5), $7.68(\mathrm{t}, J=5.9 \mathrm{~Hz}, 1 \mathrm{H}$, $-\mathrm{NHSO}_{2}-$ ), $7.58(\mathrm{~d}, J=7.4 \mathrm{~Hz}, 1 \mathrm{H}$, cipro-ArH-8), $7.38(\mathrm{~d}, J=3.7$ $\mathrm{Hz}, 1 \mathrm{H}$, thienyl-H), 6.89 (d, $J=3.8 \mathrm{~Hz}, 1 \mathrm{H}$, thienyl-H), 4.82 (br s, $1 \mathrm{H}, \mathrm{OH}), 4.62\left(\mathrm{t}, J=6.9 \mathrm{~Hz}, 2 \mathrm{H}\right.$, thiophene- $\mathrm{CH}_{2} \mathrm{CH}_{2}$-triazole + $\mathrm{OH}), 4.29(\mathrm{~s}, 1 \mathrm{H}, \mathrm{OH}), 3.84(\mathrm{~s}, 1 \mathrm{H}, c \mathrm{Pr}-\mathrm{H}), 3.44(\mathrm{t}, J=6.9 \mathrm{~Hz}, 2 \mathrm{H}$, thiophene- $\mathrm{CH}_{2} \mathrm{CH}_{2}$-triazole), $3.40(\mathrm{~s}, 1 \mathrm{H}$, glyco-H-4), $3.37(1 \mathrm{H}$, glyco- $\mathrm{H}-5$, extracted from HSQC), $3.35\left(4 \mathrm{H}, 2 \mathrm{x}\right.$ piperazine- $\left.\mathrm{CH}_{2}\right)$, $3.28-3.20\left(\mathrm{~m}, 2 \mathrm{H},-\mathrm{C}_{2} \mathrm{NSO}_{2}-+\right.$ glyco-H-3), $3.15(\mathrm{t}, J=9.3 \mathrm{~Hz}$, $1 \mathrm{H}$, glyco-H-2), $3.02(\mathrm{td}, J=8.8,2.3 \mathrm{~Hz}, 1 \mathrm{H}$, glyco-H- 1$), 2.85(\mathrm{t}, J=$ $7.5 \mathrm{~Hz}, 2 \mathrm{H},-$ triazole- $\mathrm{CH}_{2} \mathrm{CH}_{2} \mathrm{NRR}^{\prime}$ ), 2.74 (ddd, $J=13.6,8.4,5.7$ $\mathrm{Hz}, 1 \mathrm{H},-\mathrm{CH}_{2}{ }^{\prime} \mathrm{NSO}_{2}-$ ), 2.68 (br s, $6 \mathrm{H}, 2 \mathrm{x}$ piperazine- $\mathrm{CH}_{2}+$ -triazole- $\left.\mathrm{CH}_{2} \mathrm{CH}_{2} \mathrm{NRR}^{\prime}\right), 1.91$ (s, 0H), $1.35-1.29(\mathrm{~m}, 2 \mathrm{H}, c \mathrm{Pr}-$ $\left.\mathrm{CH}_{2}\right), 1.22-1.16\left(\mathrm{~m}, 2 \mathrm{H}, \mathrm{cPr}-\mathrm{CH}_{2}\right), 1.08(\mathrm{~d}, J=6.4 \mathrm{~Hz}, 3 \mathrm{H}$, glyco-H6). ${ }^{13} \mathrm{C}$ NMR (126 MHz, DMSO- $\left.d_{6}\right) \delta 176.37$ (cipro-C4=O), $165.97(\underline{\mathrm{COOH}}), 153.03$ (d, $J=250.0 \mathrm{~Hz}$, cipro-C-6), 148.02 (ciproC-2), 146.17 (Ar-C), 145.17 (d, $J=10.4 \mathrm{~Hz}$, cipro-C-7), triazole-C not found, 139.66 (Ar-C), 139.21 (cipro-C-8a), 131.18 (Ar-C), 126.45 (Ar-C), 122.47 (triazole-CH), 118.57 (d, $J=7.4 \mathrm{~Hz}$, cipro-C4a), 110.95 (d, $J=23.1 \mathrm{~Hz}$, cipro-C-5), 106.73 (cipro-C-3), 106.37 (d, $J=2.5 \mathrm{~Hz}$, cipro-C-8), 78.24 (glyco-C-2), 74.65 (glyco-C-3), 73.63 (glyco-C-5), 71.57 (glyco-C-4), 68.31 (glyco-C-1), 57.16 (linker- $\mathrm{CH}_{2}$ ), 52.15 (piperazine), 49.88 (linker- $\mathrm{CH}_{2}$ ), 49.32 (piperazine), 44.74 (glyco- $\left.\underline{\mathrm{CH}}_{2}\right), 35.89$ (cPr- $\left.\mathrm{CH}\right), 29.99$ (linker- $\left.\mathrm{CH}_{2}\right)$, 22.87 (linker- $\left.\mathrm{CH}_{2}\right), 16.93$ (glyco-C-6), $7.59\left(c \mathrm{Pr}-\mathrm{CH}_{2}\right)$. HR-MS calcd $\left[\mathrm{C}_{34} \mathrm{H}_{43} \mathrm{FN}_{7} \mathrm{O}_{9} \mathrm{~S}_{2}\right]^{+}:$: 776.2542, found 776.2538 .

Competitive Binding Assays. LecA (According to Joachim et al. ${ }^{58}$ ). A serial dilution of the test compounds was prepared in TBS/ 
$\mathrm{Ca}\left(8.0 \mathrm{~g} / \mathrm{L} \mathrm{NaCl}, 2.4 \mathrm{~g} / \mathrm{L}\right.$ Tris, $0.19 \mathrm{~g} / \mathrm{L} \mathrm{KCl}, 0.15 \mathrm{~g} / \mathrm{L} \mathrm{CaCl}_{2}$. $2 \mathrm{H}_{2} \mathrm{O}$ ), with $30 \% \mathrm{DMSO}$ as a co-solvent. A concentrated solution of LecA was diluted in TBS/Ca together with the fluorescent reporter ligand ( $N$-(fluorescein-5-yl)- $N^{\prime}-(\beta$-D-(m-aminophenyl)galactopyranosyl)thiocarbamide) to yield concentrations of $40 \mu \mathrm{M}$ and $20 \mathrm{nM}$, respectively. A $10 \mu \mathrm{L}$ solution of this mix was added to 10 $\mu \mathrm{L}$ serial dilutions of the test compounds in a black 384-well microtiter plates (Greiner Bio-One, Germany, cat. no. 781900) in triplicate. After centrifugation $(2680 \mathrm{rcf}, 1 \mathrm{~min}, \mathrm{r.t}$ ), the reactions were incubated for $30-60 \mathrm{~min}$ at r.t. in a humidity chamber. Fluorescence (excitation $485 \mathrm{~nm}$, emission $535 \mathrm{~nm}$ ) was measured in parallel and perpendicular to the excitation plane on a PheraStar FS plate reader (BMG Labtech $\mathrm{GmbH}$, Germany). The measured intensities were reduced by the values of only LecA in TBS/Ca, and fluorescence polarization was calculated. The data were analyzed with the MARS Data Analysis Software (BMG Labtech GmbH, Germany) and fitted according to the four-parameter variable slope model. Bottom and top plateaus were fixed according to the control compounds in each assay ( $p$-nitrophenyl)- $\beta$-D-galactoside), and the data was reanalyzed with these values fixed. A minimum of three independent measurements on three plates was performed for each inhibitor.

LeCB (LecB $B_{P A O 1}$ According to Hauck et al. ${ }^{41}$ and LecB $B_{P A 14}$ According to Sommer et al. ${ }^{33}$ ). A serial dilution of the test compounds was prepared in TBS/Ca, with $10 \% \mathrm{DMSO}$ as a cosolvent. A concentrated solution of LecB PAO1 or PA14 was diluted in TBS/Ca together with the fluorescent reporter ligand $(\mathrm{N}$ (fluorescein-5-yl)- $N^{\prime}$-( $\alpha$-L-fucopyranosyl ethylene)thiocarbamide) to yield concentrations of $300 \mathrm{nM}$ and $20 \mathrm{nM}$, respectively. A $10 \mu \mathrm{L}$ solution of this mix was added to $10 \mu \mathrm{L}$ serial dilutions of the test compounds in a black 384-well microtiter plates (Greiner Bio-One, Germany, cat. no. 781900 ) in triplicate. After centrifugation (2680 rcf, $1 \mathrm{~min}$, r.t.), the reactions were incubated for $4-8 \mathrm{~h}$ at r.t. in a humidity chamber. Fluorescence was measured and analyzed as for LecA. Bottom and top plateaus were fixed according to the control compound in each assay ( $\mathrm{L}$-fucose), and the data were reanalyzed with these values fixed. A minimum of three independent measurements on three plates was performed for each inhibitor.

Gyrase Supercoiling Inhibition. The assay was performed with the E. coli gyrase supercoiling kit (Inspiralis, Norwich, UK) according to the manufacturer's instructions. All pipetting steps before the reaction was started were performed on ice. A serial dilution of the test compounds was prepared in 5\% DMSO in water. A mix of relaxed pBR322 DNA (5.5 $\mu \mathrm{g}), 66 \mu \mathrm{L}$ assay buffer $(5 \mathrm{x})$, and $192.5 \mu \mathrm{L}$ water was prepared. $3 \mu \mathrm{L}$ of the dilution series (or $3 \mu \mathrm{L} 5 \% \mathrm{DMSO}$ in water for control reactions) was added. $10 \mathrm{U}$ gyrase $(2 \mu \mathrm{L}, 5 \mathrm{U} / \mu \mathrm{L})$ was diluted in $28 \mu \mathrm{L}$ dilution buffer. $3 \mu \mathrm{L}$ of the gyrase $(1 \mathrm{U})$ solution was added to the reaction mixtures. For the negative control, $3 \mu \mathrm{L}$ of dilution buffer was added instead of the enzyme. The reaction was incubated for $30 \mathrm{~min}$ at $37^{\circ} \mathrm{C}$. The reactions were stopped by the addition of $30 \mu \mathrm{L}$ of STE-buffer $(40 \%(\mathrm{~m} / \mathrm{v})$ sucrose, $100 \mathrm{mM}$ Tris. $\mathrm{HCl}, \mathrm{pH} 8,10 \mathrm{mM}$ EDTA, $\mathrm{pH} 8,0.5 \mathrm{mg} / \mathrm{mL}$ bromophenol blue) and $30 \mu \mathrm{L}$ of $\mathrm{CHCl}_{3}$ /isoamyl alcohol (24:1) and vortexing. After centrifugation $\left(17,600 \mathrm{rcf}, 1 \mathrm{~min}, 4^{\circ} \mathrm{C}\right), 50 \mu \mathrm{L}$ of the aqueous layer was loaded on an agarose gel (1\%, Tris-EDTA-acetate buffer). The gel was run for $3 \mathrm{~h}$ at $85 \mathrm{~V}$, and DNA was visualized afterward by staining with ethidium bromide. Agarose gels were digitalized using the E-box VX2 gel documentation instrument (Vilber, Eberhardzell, Germany). The fluorescence intensity of each supercoiled band was quantified using ImageJ (Version 1.52a, National Institute of Health, USA). The data were analyzed using GraphPad Prism (Version $6.0 \mathrm{~h}$, GraphPad Software, USA) and fitted against inhibitor concentration according to the four-parameter variable slope model to determine $\mathrm{IC}_{50}$ values. Bottom plateaus were fixed to 0 . A minimum of three different experiments was performed for each inhibitor.

Bacterial Strain List. All microorganisms were obtained from the German Collection of Microorganisms and Cell Cultures (DSMZ) and the American Type Culture Collection (ATCC) or were part of our internal strain collection. The following strains were used: Escherichia coli DSM 1116 (source: Rolf Müller, HIPS), Escherichia coli K12 MG1655 (source: Winfried Boos, Universität Konstanz), Staphylococcus carnosus DSM 20501 (source: Rolf Müller, HIPS), Pseudomonas aeruginosa PA14 wt (DSM 19882), Pseudomonas aeruginosa PAO1 wt (DSM 19880), Pseudomonas aeruginosa PA14 $\Delta$ lecA (Wagner et al., in preparation), and Pseudomonas aeruginosa PA14 $\Delta$ lecB (Wagner et al., in preparation).

Antibiotic Susceptibility (MIC Assay). The antibiotic activity of the synthesized conjugates was determined by broth microdilution assay based on the EUCAST guidelines, according to Wiegand, Hilpert, and Hancock. ${ }^{74}$ Serial dilutions in sterile Müller-Hinton broth II (Fluka analytical, cat. no. 90922: $17.5 \mathrm{~g} / \mathrm{L}$ casein acid hydrolysate, $3 \mathrm{~g} / \mathrm{L}$ beef extract, $1.5 \mathrm{~g} / \mathrm{L}$ starch, supplemented with $20-25 \mathrm{mg} / \mathrm{L} \mathrm{Ca}^{2+}$ and $10-15 \mathrm{mg} / \mathrm{L} \mathrm{Mg}^{2+}, \mathrm{pH} 7.3$ ) of the conjugates $21-31$ and 20 were prepared from $100 \mathrm{mM}$ DMSO stocks (for ciprofloxacin (3), a 10 $\mathrm{mM}$ aq. stock of ciprofloxacin. $\mathrm{HCl}$ was used), in sterile 96 -well plates, yielding a concentration range from 128 to $0.125 \mu \mathrm{g} / \mathrm{mL}$ (12.80.0125 for ciprofloxacin). Bacterial strains were streaked on LB-agar plates ( $1 \%$ agar) from glycerol stocks and incubated at $37{ }^{\circ} \mathrm{C}$ overnight. Colonies were picked from plate and dispersed in fresh Müller-Hinton broth II (MHB II) to yield an $\mathrm{OD}_{600}$ of $0.08-0.13$. This dispersion was diluted 1:100 in fresh MHB II, which was then used for the assay to achieve a final inoculum of $5 \times 10^{5} \mathrm{CFU} / \mathrm{mL}$. If indicated, PMBN was added to this inoculum at $2 \mu \mathrm{g} / \mathrm{mL}$. A $50 \mu \mathrm{L}$ inoculum was mixed with $50 \mu \mathrm{L}$ of the serial dilution in the corresponding well of the 96-well plate. The plates were incubated at $37{ }^{\circ} \mathrm{C}$ for $18-20 \mathrm{~h}$ in a humid incubator. Growth inhibition was assessed by visual inspection, and the given MIC values are the lowest concentration of the antibiotic at which there was no visible growth.

Biofilm Accumulation Assay. Bacterial precultures of $P$. aeruginosa PAO1 were prepared in $10 \mathrm{~mL}$ of $\mathrm{LB}$ and grown at $37{ }^{\circ} \mathrm{C}$ and 180 rpm overnight. The bacterial precultures were diluted in fresh LB to $50 \mathrm{~mL}$ and centrifuged ( $5925 \mathrm{rcf}, 10 \mathrm{~min}$, r.t.). The supernatant was discarded, and the pellet was resuspended and washed in $50 \mathrm{~mL}$ of fresh LB and centrifuged again (5925 rcf, $10 \mathrm{~min}$, r.t.). The supernatant was discarded and the pellet was again resuspended in fresh $\mathrm{LB}$ to yield an $\mathrm{OD}_{600}$ of 0.1 . Then, $150 \mu \mathrm{L}$ of this inoculum were transferred to each well of a 96-well MBEC assay plate (SKU: 19113, Category: Well Base, Innovotech Inc., Canada). The outer wells were filled with $150 \mu \mathrm{L}$ of sterile $\mathrm{LB}$ as a control. Plates were incubated at $37{ }^{\circ} \mathrm{C}, 125 \mathrm{rpm}$, and $75 \%$ humidity for $24 \mathrm{~h}$. Compound solutions $(170 \mu \mathrm{L}, 200 \mu \mathrm{M}, 1 \% \mathrm{DMSO})$ in phosphate-buffered saline $\mathrm{pH} 7.4$, supplemented with $100 \mu \mathrm{M} \mathrm{CaCl}_{2}$ (PBS/Ca) were dispensed in a 96well plate (cat. no. 167008, Nunc MicroWell 96-Well Microplates, Thermo Scientific) in quintuplicate on plates. Each peg of the biofilm covered peg lid was washed in $200 \mu \mathrm{L}$ of PBS/Ca in a 96-well plate (Nunc) for $1 \mathrm{~min}$ at r.t. and then incubated with the compound solution for 5 or $10 \mathrm{~min}$ at $37^{\circ} \mathrm{C}, 80 \mathrm{rpm}$ under humid conditions. After the incubation step, the pegs were again washed with $200 \mu \mathrm{L}$ of $\mathrm{PBS} / \mathrm{Ca}$ in a 96-well format for $30 \mathrm{~s}$ at r.t. and transferred to a last 96well plate (Nunc) filled with $170 \mu \mathrm{L}$ PBS/Ca per well. The plate was sealed with parafilm and sonicated for 15 min using an ultrasound bath. A $100 \mu \mathrm{L}$ sample of each well was transferred to a vial and treated with $100 \mu \mathrm{L}$ of $\mathrm{MeCN}$ (spiked with $1.5 \mu \mathrm{M}$ diphenhydramine. $\mathrm{HCl}$ as an internal standard). After centrifugation (17,600 rcf, $10 \mathrm{~min}$, $4{ }^{\circ} \mathrm{C}$ ), the compound concentration in the supernatant was determined by LC-MS/MS. Fresh calibration curves for each compound were prepared in the same matrix for each experiment. In each assay, the accumulation factor relative to ciprofloxacin was determined. Statistical analysis (unpaired $t$-test) was performed using the GraphPad-Prism QuickCalcs online tool (https://www.graphpad. com/quickcalcs/contMenu/).

LC-MS/MS. LC-MS/MS analysis was performed on an Ultimate 3000 system (degasser, pump, autosampler, column compartment) equipped with a Nucleodur C18 Pyramid column $(150 \times 2 \mathrm{~mm}, 3$ $\mu \mathrm{m}$, Macherey-Nagel, Düren, Germany) coupled to a TSQ Quantum Access MAX (Thermo Fisher Scientific, Waltham MA) with the following gradient conditions: A, water ( $0.1 \%$ formic acid); B, acetonitrile ( $0.1 \%$ formic acid); flow $0.600 \mathrm{~mL} / \mathrm{min}$; $90 \%$ A for 1.0 $\mathrm{min}$; $90-5 \% \mathrm{~A}$ in $0.7 \mathrm{~min}$; $5 \% \mathrm{~A}$ for $1.8 \mathrm{~min}$; equilibration at $90 \% \mathrm{~A}$ 
for $1.0 \mathrm{~min}$. MS was operated in positive SRM mode with the following mass transitions:

Diphenhydramin (IS): $256.04-164.90 ; 256.04-166.90$

Ciprofloxacin (3): 332.063-230.908; 332.063-244.968; spray voltage: $4001 \mathrm{~V}$, vaporizer temperature: $420{ }^{\circ} \mathrm{C}$, sheath gas pressure: $50 \mathrm{psi}$, ion sweep pressure: $2.5 \mathrm{psi}$, aux gas pressure: $30 \mathrm{psi}$, capillary temperature: $260{ }^{\circ} \mathrm{C}$, tube lens offset: $97 \mathrm{~V}$, skimmer offset: $0 \mathrm{~V}$, collision pressure: $1.5 \mathrm{mT}$ Tor, collision energy: $36 \mathrm{eV}$ (230.908), 23 $\mathrm{eV}$ (244.968).

(21): $740.140-559.933 ; 740.140-577.966$; spray voltage: $3000 \mathrm{~V}$, vaporizer temperature: $470{ }^{\circ} \mathrm{C}$, sheath gas pressure: $60 \mathrm{psi}$, ion sweep pressure: $0 \mathrm{psi}$, aux gas pressure: $55 \mathrm{psi}$, capillary temperature: $296^{\circ} \mathrm{C}$, tube lens offset: $99 \mathrm{~V}$, skimmer offset: $0 \mathrm{~V}$, collision pressure: 1.5 mTorr, collision energy: $36 \mathrm{eV}$ (559.933), $27 \mathrm{eV}$ (577.966).

(29): 762.124-726.026; 762.124-744.061; spray voltage: $4500 \mathrm{~V}$, vaporizer temperature: $223^{\circ} \mathrm{C}$, sheath gas pressure: $60 \mathrm{psi}$, ion sweep pressure: $0 \mathrm{psi}$, aux gas pressure: $55 \mathrm{psi}$, capillary temperature: $284^{\circ} \mathrm{C}$, tube lens offset: $99 \mathrm{~V}$, skimmer offset: $0 \mathrm{~V}$, collision pressure: 1.5 mTorr, collision energy: $33 \mathrm{eV}$ (726.026), $29 \mathrm{eV}$ (744.061).

Cytotoxicity (MTT Assay, According to Haupenthal et al. ${ }^{75}$ ). HEK293 or A549 cells $\left(2 \times 10^{5}\right.$ cells per well $)$ were seeded in 24-well, flat-bottom plates. Culturing of cells, incubations, and OD measurements were performed as described with small modifications. Twentyfour hours after seeding the cells, the incubation was started by the addition of compounds in a final DMSO concentration of $1 \%$. The living cell mass was determined after $48 \mathrm{~h}$ in a PHERAstar microplate reader (BMG Labtech, Ortenberg, Germany). Two independent measurements were performed for each compound.

Microsomal Stability. Microsomal stability was performed as previously described in Sommer et al. ${ }^{44}$

Plasma Protein Binding. Plasma protein binding was measured with a rapid equilibrium dialysis assay plate (Thermo Fisher Scientific, Waltham MA). On one side of the membrane, $150 \mu \mathrm{L}$ of human plasma (seralab-BioIVT, West Sussex United Kingdom) and $150 \mu \mathrm{L}$ of PBS pH 7.4 (Gibco Thermo Fisher Scientific, Waltham MA) were added to the well; on the other side, $550 \mu \mathrm{L}$ of PBS was added to the well. The compound was added to a final concentration of $1 \mu \mathrm{M}$ to the plasma-containing well. The plate was closed and incubated in an orbital shaker at $37^{\circ} \mathrm{C}$ for $6 \mathrm{~h}$ at $750 \mathrm{rpm}$. Samples of $10 \mu \mathrm{L}$ from each well were taken at 0,5 , and $6 \mathrm{~h}$ and mixed with $90 \mu \mathrm{L}$ of ice-cold acetonitrile with internal standard diphenhydramine $(1 \mu \mathrm{M})$. The concentration of compound in the supernatant was analyzed with LCMS/MS. Plasma protein binding was calculated from the concentration difference between the wells. Five and $6 \mathrm{~h}$ samples were compared to ensure equilibrium. Warfarin was used as an assay control.

Human Plasma Stability. Compound stability in plasma was measured by incubation with plasma and LC-MS/MS quantification of the remaining compound. A $195 \mu \mathrm{L}$ solution of human plasma (seralab-BioIVT, West Sussex, United Kingdom) was incubated with $5 \mu \mathrm{L}$ of compound ( $40 \mu \mathrm{M}$ stock) at $37^{\circ} \mathrm{C}$ for $0,5,60$, and $150 \mathrm{~min}$. Then, $800 \mu \mathrm{L}$ of ice-cold acetonitrile containing internal standard diphenhydramine $(1 \mu \mathrm{M})$ was added. The concentration of remaining compound in the supernatant was determined via LC-MS/MS measurement. Procaine was used as an activity control of plasma metabolism.

Cell Permeability. Permeability of the compound was assessed in vitro with Calu-3 HTB-55 cell line (ATCC). Cells were cultivated in minimum essential medium supplemented with Earle's salts, Lglutamine, $10 \%$ FCS, $1 \%$ non-essential amino acids (NEAA), and 1 $\mathrm{mM}$ sodium pyruvate. Passages between 35 and 55 were used, and the medium was changed every $2-3$ days. For experiments, cells were harvested using Trypsin/EDTA and $1 \times 10^{5}$ cells seeded on Transwell inserts 3460. Cells were grown in an air-liquid interface beginning at day 3 and used for transport studies on days 11-13. TEER values exceeded $300 \Omega \cdot \mathrm{cm}^{2}$ before beginning transport studies. For experiments, Krebs-Ringer solution with $1 \%$ BSA was used and cells were accommodated to the buffer for at least $1 \mathrm{~h}$ with no decrease in TEER. Samples $(200 \mu \mathrm{L})$ were taken in regular intervals from the apical side (time intervals of $0,20,40,60,90,120,180$, and $240 \mathrm{~min}$ ) and replenished with fresh buffer. TEER was monitored during the experiment, and epithelial barriers were considered compromised if the TEER fell below $300 \Omega \cdot \mathrm{cm}^{2}$ during $4 \mathrm{~h}$ of experiment duration. Fluorescein sodium salt and ciprofloxacin $\cdot \mathrm{HCl}$ were used as a control. A $50 \mu \mathrm{L}$ sample was mixed with $150 \mu \mathrm{L}$ of ice-cold acetonitrile containing internal standard diphenhydramine $(1 \mu \mathrm{M})$, and the concentration of compound was analyzed with LC-MS/MS.

\section{ASSOCIATED CONTENT}

\section{s) Supporting Information}

The Supporting Information is available free of charge at https://pubs.acs.org/doi/10.1021/acs.jmedchem.0c00856.

${ }^{1} \mathrm{H}$ and ${ }^{13} \mathrm{C}$ NMR spectra of new compounds; gyrase supercoiling inhibition assay gels; $P$. aeruginosa $\mathrm{PAO} 1$ biofilm accumulation raw data; lectin inhibition $K_{\mathrm{i}}$ values calculated from $\mathrm{IC}_{50}$; antibiotic susceptibility in molar concentration; key compounds and intermediates as SMILES; purity of key compounds 11-14, 19-31 by HPLC-UV; and retention times and a representative chromatogram of conjugates 22-31 and ciprofloxacin (3) from slow gradient HPLC runs for lipophilicity comparison (PDF)

Molecular formula strings for all new compounds and key compounds (5-14, 16, and 19-31) (CSV)

\section{AUTHOR INFORMATION}

\section{Corresponding Author}

Alexander Titz - Chemical Biology of Carbohydrates $(\mathrm{CBCH})$, Helmholtz Institute for Pharmaceutical Research Saarland (HIPS), Helmholtz Centre for Infection Research, D-66123 Saarbrücken, Germany; Deutsches Zentrum für Infektionsforschung (DZIF), Standort Hannover-Braunschweig, D-38124 Braunschweig, Germany; Department of Pharmacy and Department of Chemistry, Saarland University, D-66123 Saarbrücken, Germany; 이이.org/0000-0001-7408-5084; Phone: +49 68199806 2500; Email: alexander.titz@ helmholtz-hzi.de

\section{Authors}

Joscha Meiers - Chemical Biology of Carbohydrates $(\mathrm{CBCH})$, Helmholtz Institute for Pharmaceutical Research Saarland (HIPS), Helmholtz Centre for Infection Research, D-66123 Saarbrücken, Germany; Deutsches Zentrum für Infektionsforschung (DZIF), Standort Hannover-Braunschweig, D-38124 Braunschweig, Germany; Department of Pharmacy and Department of Chemistry, Saarland University, D-66123 Saarbrücken, Germany

Eva Zahorska - Chemical Biology of Carbohydrates ( $\mathrm{CBCH})$, Helmholtz Institute for Pharmaceutical Research Saarland (HIPS), Helmholtz Centre for Infection Research, D-66123 Saarbrücken, Germany; Deutsches Zentrum für Infektionsforschung (DZIF), Standort Hannover-Braunschweig, D-38124 Braunschweig, Germany; Department of Pharmacy and Department of Chemistry, Saarland University, D-66123 Saarbrücken, Germany

Teresa Röhrig - Deutsches Zentrum für Infektionsforschung (DZIF), Standort Hannover-Braunschweig, D-38124 Braunschweig, Germany; Drug Design and Optimization (DDOP), Helmholtz Institute for Pharmaceutical Research Saarland (HIPS), Helmholtz Centre for Infection Research, D66123 Saarbrücken, Germany

Dirk Hauck - Chemical Biology of Carbohydrates ( $\mathrm{CBCH})$, Helmholtz Institute for Pharmaceutical Research Saarland 
(HIPS), Helmholtz Centre for Infection Research, D-66123 Saarbrücken, Germany; Deutsches Zentrum für Infektionsforschung (DZIF), Standort Hannover-Braunschweig, D-38124 Braunschweig, Germany

Stefanie Wagner - Chemical Biology of Carbohydrates $(\mathrm{CBCH})$, Helmholtz Institute for Pharmaceutical Research Saarland (HIPS), Helmholtz Centre for Infection Research, D66123 Saarbrücken, Germany; Deutsches Zentrum für Infektionsforschung (DZIF), Standort Hannover-Braunschweig, D-38124 Braunschweig, Germany

Complete contact information is available at:

https://pubs.acs.org/10.1021/acs.jmedchem.0c00856

\section{Author Contributions}

J.M. synthesized conjugates and individual building blocks. D.H. synthesized compound 17. J.M. and E.Z. performed lectin inhibition assays. J.M. performed gyrase supercoiling inhibition, antibiotic susceptibility, and biofilm accumulation assays. T.R. analyzed data for metabolic stability in human plasma, plasma protein binding, and acute cytotoxicity. S.W. provided conceptual advice and analyzed the data. J.M. and A.T. conceived the study. J.M. and A.T. wrote the paper with input from all coauthors.

\section{Notes}

The authors declare no competing financial interest.

\section{ACKNOWLEDGMENTS}

The authors are thankful to Prof. Dr. Rolf Müller and Dr. Jennifer Hermann (HIPS) for scientific discussions and for providing the bacterial strains S. carnosus DSM 20501 and E. coli DSM 1116. We are grateful to Dr. Thomas Ryckmans (F. Hoffmann la Roche, Basel) for metabolic stability assays against human liver microsomes and mouse liver microsomes, Tabea Wittmann and Dennis Jener (HIPS) for plasma stability, plasma protein binding, and cytotoxicity assays, and Justus Horstmann (HIPS) for cell permeation measurements. A.T. acknowledges financial support from the Helmholtz Association (VH-NG-934), the European Research Council (ERC Starting Grant, Sweetbullets), and DZIF.

\section{LIST OF ABBREVIATIONS}

XDR, extensively drug-resistant; WHO, World Health Organization; P. aeruginosa, Pseudomonas aeruginosa; MLM, mouse liver microsomes; HLM, human liver microsomes; PE, petroleum ether; $\mathrm{CL}_{\mathrm{MIC}}$, microsomal clearance; $c \mathrm{Pr}$, cyclopropyl; rcf, relative centrifugal force; LR-MS, low-resolution mass spectrometry

\section{REFERENCES}

(1) Rice, L. B. Federal funding for the study of antimicrobial resistance in nosocomial pathogens: no ESKAPE. J. Infect. Dis. 2008, 197, 1079-1081.

(2) Boucher, H. W.; Talbot, G. H.; Bradley, J. S.; Edwards, J. E.; Gilbert, D.; Rice, L. B.; Scheld, M.; Spellberg, B.; Bartlett, J. Bad bugs, no drugs: no ESKAPE! An update from the Infectious Diseases Society of America. Clin. Infect. Dis. 2009, 48, 1-12.

(3) Rice, L. B. Progress and challenges in implementing the research on ESKAPE pathogens. Infect. Control Hosp. Epidemiol. 2010, 31, S7S10.

(4) Meynard, J.-L.; Barbut, F.; Guiguet, M.; Batissel, D.; Lalande, V.; Lesage, D.; Guiard-Schmid, J.-B.; Petit, J.-C.; Frottier, J.; Meyohas, M.-C. Pseudomonas aeruginosa infection in human immunodeficiency virus infected patients. J. Infect. 1999, 38, 176-181.
(5) Rizzi, E. B.; Schininà, V.; Bordi, E.; Buontempo, G.; Narciso, P.; Bibbolino, C. HIV-related bronchopulmonary infection by pseudomonas aeruginosa in the HAART era: radiological findings. Acta Radiol. 2006, 47, 793-797.

(6) Bodey, G. P. Pseudomonas aeruginosa infections in cancer patients: have they gone away? Curr. Opin. Infect. Dis. 2001, 14, 403407.

(7) Hauser, A. R.; Rello, J. Severe infections caused by Pseudomonas aeruginosa; Springer Science \& Business Media: Boston, MA, 2012.

(8) Poole, K. Pseudomonas aeruginosa: resistance to the max. Front. Microbiol. 2011, 2, 65.

(9) WHO publishes list of bacteria for which new antibiotics are urgently needed; World Health Organization: Geneva, 2017 Available at: https://www.who.int/news-room/detail/27-02-2017-who-publisheslist-of-bacteria-for-which-new-antibiotics-are-urgently-needed. (accessed January 2020)

(10) Suci, P. A.; Mittelman, M. W.; Yu, F. P.; Geesey, G. G. Investigation of ciprofloxacin penetration into Pseudomonas aeruginosa biofilms. Antimicrob. Agents Chemother. 1994, 38, 21252133.

(11) Flemming, H.-C.; Wingender, J. The biofilm matrix. Nat. Rev. Microbiol. 2010, 8, 623-633.

(12) Davies, D. Understanding biofilm resistance to antibacterial agents. Nat. Rev. Drug Discovery 2003, 2, 114-122.

(13) Winzer, K.; Falconer, C.; Garber, N. C.; Diggle, S. P.; Camara, M.; Williams, P. The Pseudomonas aeruginosa lectins PA-IL and PAIIL are controlled by quorum sensing and by RpoS. J. Bacteriol. 2000, 182, 6401-6411.

(14) Diggle, S. P.; Stacey, R. E.; Dodd, C.; Cámara, M.; Williams, P.; Winzer, K. The galactophilic lectin, LecA, contributes to biofilm development in Pseudomonas aeruginosa. Environ. Microbiol. 2006, 8, 1095-1104.

(15) Tielker, D.; Hacker, S.; Loris, R.; Strathmann, M.; Wingender, J.; Wilhelm, S.; Rosenau, F.; Jaeger, K.-E. Pseudomonas aeruginosa lectin LecB is located in the outer membrane and is involved in biofilm formation. Microbiology 2005, 151, 1313-1323.

(16) Gilboa-Garber, N. Pseudomonas aeruginosa lectins. Methods Enzymol. 1982, 83, 378-385.

(17) Gilboa-Garber, N.; Mizrahi, L.; Garber, N. Mannose-binding hemagglutinins in extracts of Pseudomonas aeruginosa. Can. J. Biochem. 1977, 55, 975-981.

(18) Gilboa-Garber, N. Purification and properties of hemagglutinin from Pseudomonas aeruginosa and its reaction with human blood cells. Biochim. Biophys. Acta, Gen. Subj. 1972, 273, 165-173.

(19) da Silva, D. P.; Matwichuk, M. L.; Townsend, D. O.; Reichhardt, C.; Lamba, D.; Wozniak, D. J.; Parsek, M. R. The Pseudomonas aeruginosa lectin LecB binds to the exopolysaccharide Psl and stabilizes the biofilm matrix. Nat. Commun. 2019, 10, 2183.

(20) Adam, E. C.; Mitchell, B. S.; Schumacher, D. U.; Grant, G.; Schumacher, U. Pseudomonas aeruginosa II lectin stops human ciliary beating: therapeutic implications of fucose. Am. J. Respir. Crit. Care Med. 1997, 155, 2102-2104.

(21) Landi, A.; Mari, M.; Kleiser, S.; Wolf, T.; Gretzmeier, C.; Wilhelm, I.; Kiritsi, D.; Thünauer, R.; Geiger, R.; Nyström, A.; Reggiori, F.; Claudinon, J.; Römer, W. Pseudomonas aeruginosa lectin LecB impairs keratinocyte fitness by abrogating growth factor signalling. Life Sci. Alliance 2019, 2, No. e201900422.

(22) Cott, C.; Thuenauer, R.; Landi, A.; Kühn, K.; Juillot, S.; Imberty, A.; Madl, J.; Eierhoff, T.; Römer, W. Pseudomonas aeruginosa lectin LecB inhibits tissue repair processes by triggering $\beta$-catenin degradation. Biochim. Biophys. Acta, Mol. Cell Res. 2016, 1863, 1106-1118.

(23) Wilhelm, I.; Levit-Zerdoun, E.; Jakob, J.; Villringer, S.; Frensch, M.; Übelhart, R.; Landi, A.; Müller, P.; Imberty, A.; Thuenauer, R.; Claudinon, J.; Jumaa, H.; Reth, M.; Eibel, H.; Hobeika, E.; Römer, W. Carbohydrate-dependent $\mathrm{B}$ cell activation by fucose-binding bacterial lectins. Sci. Signaling 2019, 12, No. eaao7194.

(24) Zheng, S.; Eierhoff, T.; Aigal, S.; Brandel, A.; Thuenauer, R.; de Bentzmann, S.; Imberty, A.; Römer, W. The Pseudomonas aeruginosa 
lectin LecA triggers host cell signalling by glycosphingolipiddependent phosphorylation of the adaptor protein CrkII. Biochim. Biophys. Acta, Mol. Cell Res. 2017, 1864, 1236-1245.

(25) Eierhoff, T.; Bastian, B.; Thuenauer, R.; Madl, J.; Audfray, A.; Aigal, S.; Juillot, S.; Rydell, G. E.; Muller, S.; de Bentzmann, S.; Imberty, A.; Fleck, C.; Romer, W. A lipid zipper triggers bacterial invasion. Proc. Natl. Acad. Sci. U. S. A. 2014, 111, 12895-12900.

(26) Boukerb, A. M.; Rousset, A.; Galanos, N.; Méar, J.-B.; Thépaut, M.; Grandjean, T.; Gillon, E.; Cecioni, S.; Abderrahmen, C.; Faure, K.; Redelberger, D.; Kipnis, E.; Dessein, R.; Havet, S.; Darblade, B.; Matthews, S. E.; de Bentzmann, S.; Guéry, B.; Cournoyer, B.; Imberty, A.; Vidal, S. Antiadhesive properties of glycoclusters against Pseudomonas aeruginosa lung infection. J. Med. Chem. 2014, 57, 10275-10289.

(27) Chemani, C.; Imberty, A.; de Bentzmann, S.; Pierre, M.; Wimmerová, M.; Guery, B. P.; Faure, K. Role of LecA and LecB lectins in Pseudomonas aeruginosa-induced lung injury and effect of carbohydrate ligands. Infect. Immun. 2009, 77, 2065-2075.

(28) von Bismarck, P.; Schneppenheim, R.; Schumacher, U. Successful treatment of Pseudomonas aeruginosa respiratory tract infection with a sugar solution - a case report on a lectin based therapeutic principle. Klin. Paediatr. 2001, 213, 285-287.

(29) Hauber, H.-P.; Schulz, M.; Pforte, A.; Mack, D.; Zabel, P.; Schumacher, U. Inhalation with fucose and galactose for treatment of Pseudomonas aeruginosa in cystic fibrosis patients. Int. J. Med. Sci. 2008, 5, 371-376.

(30) Bucior, I.; Abbott, J.; Song, Y.; Matthay, M. A.; Engel, J. N. Sugar administration is an effective adjunctive therapy in the treatment of Pseudomonas aeruginosa pneumonia. Am. J. Physiol.: Lung Cell. Mol. Physiol. 2013, 305, L352-L363.

(31) Klockgether, J.; Cramer, N.; Wiehlmann, L.; Davenport, C. F.; Tümmler, B. Pseudomonas aeruginosa genomic structure and diversity. Front. Microbiol. 2011, 2, 150.

(32) Dötsch, A.; Schniederjans, M.; Khaledi, A.; Hornischer, K.; Schulz, S.; Bielecka, A.; Eckweiler, D.; Pohl, S.; Häussler, S. The Pseudomonas aeruginosa transcriptional landscape is shaped by environmental heterogeneity and genetic variation. MBio 2015, 6, No. e00749.

(33) Sommer, R.; Wagner, S.; Varrot, A.; Nycholat, C. M.; Khaledi, A.; Häussler, S.; Paulson, J. C.; Imberty, A.; Titz, A. The virulence factor LecB varies in clinical isolates: consequences for ligand binding and drug discovery. Chem. Sci. 2016, 7, 4990-5001.

(34) Boukerb, A. M.; Decor, A.; Ribun, S.; Tabaroni, R.; Rousset, A.; Commin, L.; Buff, S.; Doléans-Jordheim, A.; Vidal, S.; Varrot, A.; Imberty, A.; Cournoyer, B. Genomic rearrangements and functional diversification of lecA and lecB lectin-coding regions impacting the efficacy of glycomimetics directed against Pseudomonas aeruginosa. Front. Microbiol. 2016, 7, 811.

(35) Varki, A.; Etzler, M. E.; Cummings, R. D.; Esko, J. D. Discovery and classification of glycan-binding proteins. In Essentials of Glycobiology; 2nd edition, Eds: Varki, A.; Cummings, R. D.; Esko, J. D.; Freeze, H. H.; Stanley, P.; Bertozzi, C. R.; Hart, G. W.; Etzler, M. E. Cold Spring Harbor Laboratory Press: 2009, Chapter 26. Available at: http://www.ncbi.nlm.nih.gov/books/NBK1923/.

(36) Calvert, M. B.; Jumde, V. R.; Titz, A. Pathoblockers or antivirulence drugs as a new option for the treatment of bacterial infections. Beilstein J. Org. Chem. 2018, 14, 2607-2617.

(37) Meiers, J.; Siebs, E.; Zahorska, E.; Titz, A. Lectin antagonists in infection, immunity, and inflammation. Curr. Opin. Chem. Biol. 2019, $53,51-67$.

(38) Wagner, S.; Sommer, R.; Hinsberger, S.; Lu, C.; Hartmann, R. W.; Empting, M.; Titz, A. Novel strategies for the treatment of Pseudomonas aeruginosa infections. J. Med. Chem. 2016, 59, 59295969.

(39) Cecioni, S.; Imberty, A.; Vidal, S. Glycomimetics versus multivalent glycoconjugates for the design of high affinity lectin ligands. Chem. Rev. 2015, 115, 525-561.

(40) Bernardi, A.; Jiménez-Barbero, J.; Casnati, A.; De Castro, C.; Darbre, T.; Fieschi, F.; Finne, J.; Funken, H.; Jaeger, K.-E.; Lahmann,
M.; Lindhorst, T. K.; Marradi, M.; Messner, P.; Molinaro, A.; Murphy, P. V.; Nativi, C.; Oscarson, S.; Penadés, S.; Peri, F.; Pieters, R. J.; Renaudet, O.; Reymond, J.-L.; Richichi, B.; Rojo, J.; Sansone, F.; Schäffer, C.; Turnbull, W. B.; Velasco-Torrijos, T.; Vidal, S.; Vincent, S.; Wennekes, T.; Zuilhof, H.; Imberty, A. Multivalent glycoconjugates as anti-pathogenic agents. Chem. Soc. Rev. 2013, 42, 4709-4727.

(41) Hauck, D.; Joachim, I.; Frommeyer, B.; Varrot, A.; Philipp, B.; Möller, H. M.; Imberty, A.; Exner, T. E.; Titz, A. Discovery of two classes of potent glycomimetic inhibitors of Pseudomonas aeruginosa LecB with distinct binding modes. ACS Chem. Biol. 2013, 8, 17751784.

(42) Sommer, R.; Exner, T. E.; Titz, A. A biophysical study with carbohydrate derivatives explains the molecular basis of monosaccharide selectivity of the Pseudomonas aeruginosa lectin LecB. PLoS One 2014, 9, No. e112822.

(43) Sommer, R.; Hauck, D.; Varrot, A.; Wagner, S.; Audfray, A.; Prestel, A.; Möller, H. M.; Imberty, A.; Titz, A. Cinnamide derivatives of D-mannose as inhibitors of the bacterial virulence factor LecB from Pseudomonas aeruginosa. ChemistryOpen 2015, 4, 756-767.

(44) Sommer, R.; Wagner, S.; Rox, K.; Varrot, A.; Hauck, D.; Wamhoff, E.-C.; Schreiber, J.; Ryckmans, T.; Brunner, T.; Rademacher, C.; Hartmann, R. W.; Brönstrup, M.; Imberty, A.; Titz, A. Glycomimetic, orally bioavailable LecB inhibitors block biofilm formation of Pseudomonas aeruginosa. J. Am. Chem. Soc. 2018, 140, 2537-2545.

(45) Sommer, R.; Rox, K.; Wagner, S.; Hauck, D.; Henrikus, S. S.; Newsad, S.; Arnold, T.; Ryckmans, T.; Brönstrup, M.; Imberty, A.; Varrot, A.; Hartmann, R. W.; Titz, A. Anti-biofilm agents against Pseudomonas aeruginosa: a structure-activity relationship study of Cglycosidic LecB inhibitors. J. Med. Chem. 2019, 62, 9201-9216.

(46) Cioci, G.; Mitchell, E. P.; Gautier, C.; Wimmerová, M.; Sudakevitz, D.; Pérez, S.; Gilboa-Garber, N.; Imberty, A. Structural basis of calcium and galactose recognition by the lectin PA-IL of Pseudomonas aeruginosa. FEBS Lett. 2003, 555, 297-301.

(47) Wagner, S.; Hauck, D.; Hoffmann, M.; Sommer, R.; Joachim, I.; Müller, R.; Imberty, A.; Varrot, A.; Titz, A. Covalent lectin inhibition and application in bacterial biofilm imaging. Angew. Chem., Int. Ed. 2017, 56, 16559-16564.

(48) Tanne, J. H. FDA adds 'black box' warning label to fluoroquinolone antibiotics. BMJ 2008, 337, a816.

(49) Schwartz, R. S. Paul Ehrlich's magic bullets. N. Engl. J. Med. 2004, 350, 1079-1080.

(50) Barok, M.; Joensuu, H.; Isola, J. Trastuzumab emtansine: mechanisms of action and drug resistance. Breast Cancer Res. 2014, 16, 209.

(51) Lehar, S. M.; Pillow, T.; Xu, M.; Staben, L.; Kajihara, K. K.; Vandlen, R.; DePalatis, L.; Raab, H.; Hazenbos, W. L.; Morisaki, J. H.; Kim, J.; Park, S.; Darwish, M.; Lee, B.-C.; Hernandez, H.; Loyet, K. M.; Lupardus, P.; Fong, R.; Yan, D.; Chalouni, C.; Luis, E.; Khalfin, Y.; Plise, E.; Cheong, J.; Lyssikatos, J. P.; Strandh, M.; Koefoed, K.; Andersen, P. S.; Flygare, J. A.; Tan, M. W.; Brown, E. J.; Mariathasan, $S$. Novel antibody-antibiotic conjugate eliminates intracellular $S$. aureus. Nature 2015, 527, 323-328.

(52) Zhang, G.-F.; Liu, X.; Zhang, S.; Pan, B.; Liu, M.-L. Ciprofloxacin derivatives and their antibacterial activities. Eur. J. Med. Chem. 2018, 146, 599-612.

(53) Klahn, P.; Brönstrup, M. Bifunctional antimicrobial conjugates and hybrid antimicrobials. Nat. Prod. Rep. 2017, 34, 832-885.

(54) Milner, S. J.; Carrick, C. T.; Kerr, K. G.; Snelling, A. M.; Thomas, G. H.; Duhme-Klair, A.-K.; Routledge, A. Probing bacterial uptake of glycosylated ciprofloxacin conjugates. ChemBioChem 2014, $15,466-471$.

(55) Howse, G. L.; Bovill, R. A.; Stephens, P. J.; Osborn, H. M. I. Synthesis and antibacterial profiles of targeted triclosan derivatives. Eur. J. Med. Chem. 2019, 162, 51-58.

(56) Rodrigue, J.; Ganne, G.; Blanchard, B.; Saucier, C.; Giguère, D.; Shiao, T. C.; Varrot, A.; Imberty, A.; Roy, R. Aromatic thioglycoside inhibitors against the virulence factor LecA from Pseudomonas aeruginosa. Org. Biomol. Chem. 2013, 11, 6906-6918. 
(57) Kadam, R. U.; Garg, D.; Schwartz, J.; Visini, R.; Sattler, M.; Stocker, A.; Darbre, T.; Reymond, J.-L. CH- $\pi$ 'T-shape' interaction with histidine explains binding of aromatic galactosides to Pseudomonas aeruginosa lectin LecA. ACS Chem. Biol. 2013, 8, $1925-1930$.

(58) Joachim, I.; Rikker, S.; Hauck, D.; Ponader, D.; Boden, S.; Sommer, R.; Hartmann, L.; Titz, A. Development and optimization of a competitive binding assay for the galactophilic low affinity lectin LecA from Pseudomonas aeruginosa. Org. Biomol. Chem. 2016, 14, 7933-7948.

(59) Kadam, R. U.; Bergmann, M.; Hurley, M.; Garg, D.; Cacciarini, M.; Swiderska, M. A.; Nativi, C.; Sattler, M.; Smyth, A. R.; Williams, P.; Cámara, M.; Stocker, A.; Darbre, T.; Reymond, J.-L. A Glycopeptide dendrimer inhibitor of the galactose-specific lectin LecA and of Pseudomonas aeruginosa biofilms. Angew. Chem., Int. Ed. 2011, 50, 10631-10635.

(60) Chu, D. T.; Fernandes, P. B. Structure-activity relationships of the fluoroquinolones. Antimicrob. Agents Chemother. 1989, 33, 131135.

(61) Gootz, T. D.; Brighty, K. E. Fluoroquinolone antibacterials: SAR, mechanism of action, resistance, and clinical aspects. Med. Res. Rev. 1996, 16, 433-486.

(62) Idowu, T.; Schweizer, F. Ubiquitous nature of fluoroquinolones: the oscillation between antibacterial and anticancer activities. Antibiotics 2017, 6, 26.

(63) Pham, T. D. M.; Ziora, Z. M.; Blaskovich, M. A. T. Quinolone antibiotics. Med. Chem. Commun. 2019, 10, 1719-1739.

(64) Koga, H.; Itoh, A.; Murayama, S.; Suzue, S.; Irikura, T. Structure-activity relationships of antibacterial 6,7- and 7,8-disubstituted 1-alkyl-1,4-dihydro-4-oxoquinoline-3-carboxylic acids. J. Med. Chem. 1980, 23, 1358-1363.

(65) Mustaev, A.; Malik, M.; Zhao, X.; Kurepina, N.; Luan, G.; Oppegard, L. M.; Hiasa, H.; Marks, K. R.; Kerns, R. J.; Berger, J. M.; Drlica, K. Fluoroquinolone-gyrase-DNA complexes: two modes of drug binding. J. Biol. Chem. 2014, 289, 12300-12312.

(66) Casoni, F.; Dupin, L.; Vergoten, G.; Meyer, A.; Ligeour, C.; Géhin, T.; Vidal, O.; Souteyrand, E.; Vasseur, J.-J.; Chevolot, Y.; Morvan, F. The influence of the aromatic aglycon of galactoclusters on the binding of LecA: a case study with O-phenyl, S-phenyl, Obenzyl, S-benzyl, O-biphenyl and O-naphthyl aglycons. Org. Biomol. Chem. 2014, 12, 9166-9179.

(67) Richter, M. F.; Drown, B. S.; Riley, A. P.; Garcia, A.; Shirai, T.; Svec, R. L.; Hergenrother, P. J. Predictive compound accumulation rules yield a broad-spectrum antibiotic. Nature 2017, 545, 299-304.

(68) O'Shea, R.; Moser, H. E. Physicochemical properties of antibacterial compounds: implications for drug discovery. J. Med. Chem. 2008, 51, 2871-2878.

(69) Müsken, M.; Klimmek, K.; Sauer-Heilborn, A.; Donnert, M.; Sedlacek, L.; Suerbaum, S.; Häussler, S. Towards individualized diagnostics of biofilm-associated infections: a case study. NPJ Biofilms Microbiomes 2017, 3, 22.

(70) Zięba, A.; Maślankiewicz, A.; Sitkowski, J. ${ }^{1} \mathrm{H},{ }^{13} \mathrm{C}$ and ${ }^{15} \mathrm{~N}$ NMR spectra of ciprofloxacin. Magn. Reson. Chem. 2004, 42, 903904.

(71) Driguez, H.; Szeja, W. Facile synthesis of 1,2-trans-nitrophenyl1-thioglycopyranosides. Synthesis 1994, 1994, 1413-1414.

(72) McPherson, J. C., III; Runner, R.; Buxton, T. B.; Hartmann, J. F.; Farcasiu, D.; Bereczki, I.; Rőth, E.; Tollas, S.; Ostorházi, E.; Rozgonyi, F.; Herczegh, P. Synthesis of osteotropic hydroxybisphosphonate derivatives of fluoroquinolone antibacterials. Eur. J. Med. Chem. 2012, 47, 615-618.

(73) Phiasivongsa, P.; Samoshin, V. V.; Gross, P. H. Henry condensations with 4,6-O-benzylidenylated and non-protected dglucose and L-fucose via DBU-catalysis. Tetrahedron Lett. 2003, 44, 5495-5498.

(74) Wiegand, I.; Hilpert, K.; Hancock, R. E. W. Agar and broth dilution methods to determine the minimal inhibitory concentration (MIC) of antimicrobial substances. Nat. Protoc. 2008, 3, 163-175.
(75) Haupenthal, J.; Baehr, C.; Zeuzem, S.; Piiper, A. RNAse A-like enzymes in serum inhibit the anti-neoplastic activity of siRNA targeting polo-like kinase 1. Int. J. Cancer 2007, 121, 206-210. 